



\section{Wilde bijen en zweefvliegen per landschapstype}

Wim A. Ozinga ${ }^{1}$, Jeroen A. Scheper ${ }^{1,2}$, G. Arjen de Groot $^{1}$, Menno Reemer ${ }^{3}$, Ivo Raemakers ${ }^{4}$, Coby van Dooremalen ${ }^{5}$, Koos Biesmeijer ${ }^{6}$ \& David Kleijn ${ }^{2}$

1 Wageningen Environmental Research

2 Wageningen Universiteit

3 EIS Kenniscentrum Insecten

4 Ecologica

5 Wageningen Plant Research

6 Naturalis Biodiversity Center

Dit onderzoek is uitgevoerd door Wageningen Environmental Research in opdracht van en gefinancierd door het ministerie van Landbouw, Natuur en Voedselkwaliteit, in het kader van het Beleidsondersteunend onderzoekprogramma 'Kennisimpuls bestuivers' (BO-43-011.06-007).

Wageningen Environmental Research

Wageningen, december 2018

Rapport 2920

ISSN 1566-7197 
Ozinga, W.A., J.A. Scheper, G.A. de Groot, M. Reemer, I. Raemakers, C. van Dooremalen, K. Biesmeijer \& D. Kleijn, 2018. Wilde bijen en zweefvliegen per landschapstype. Wageningen, Wageningen Environmental Research, Rapport 2920. 58 blz.; 13 fig.; 6 tab.; 43 ref.

Bij de bestuiving van veel voedselgewassen en wilde planten spelen bloembezoekende insecten een essentiële rol. Het gaat dan niet alleen over honingbijen, maar over een breed spectrum van soorten wilde bijen en zweefvliegen. Er zijn sterke aanwijzingen dat de laatste decennia zowel de aantallen als de soortendiversiteit van bestuivers sterk achteruit zijn gegaan. Via de Nationale Bijenstrategie werken het ministerie van LNV en meer dan vijftig maatschappelijke partners samen om bestuivers en bestuivingsdiensten in ons land te behouden en bevorderen. Dit is in de praktijk lastig, omdat in Nederland honderden soorten bijen en zweefvliegen voorkomen met elk hun specifieke wensen ten aanzien van hun leefgebied en omdat in verschillende landschapstypen verschillende soorten voorkomen. Maatwerk is dus geboden. In dit rapport wordt het voorkomen van bijen en zweefvliegen in verschillende landschapstypen in beeld gebracht. Doel van deze informatie is om snel inzicht te kunnen krijgen in de relevante soorten bestuivers die zouden kunnen voorkomen in een bepaalde regio, om vervolgens gerichte maatregelen te kunnen nemen die aansluiten bij de eisen die deze soorten aan hun omgeving stellen. Bij de interpretatie van het belang van de landschapstypen voor bestuivende insecten is onderscheid gemaakt tussen bedreigde soorten en soorten die in potentie een belangrijke rol kunnen spelen bij de bestuiving van landbouwgewassen.

Trefwoorden: Bestuiving, Big Data, Bijen, Bloembezoekende insecten, Clusteranalyse, Landbouwgewassen, Landschapstypen, Nationale bijenstrategie, Rode Lijst, Zweefvliegen

Dit rapport is gratis te downloaden van https://doi.org/10.18174/465935 of op www.wur.nl/environmental-research (ga naar 'Wageningen Environmental Research' in de grijze balk onderaan). Wageningen Environmental Research verstrekt geen gedrukte exemplaren van rapporten.

2018 Wageningen Environmental Research (instituut binnen de rechtspersoon Stichting Wageningen Research), Postbus 47, 6700 AA Wageningen, T 03174807 00, www.wur.nl/environmental-research. Wageningen Environmental Research is onderdeel van Wageningen University \& Research.

- Overname, verveelvoudiging of openbaarmaking van deze uitgave is toegestaan mits met duidelijke bronvermelding.

- Overname, verveelvoudiging of openbaarmaking is niet toegestaan voor commerciële doeleinden en/of geldelijk gewin.

- Overname, verveelvoudiging of openbaarmaking is niet toegestaan voor die gedeelten van deze uitgave waarvan duidelijk is dat de auteursrechten liggen bij derden en/of zijn voorbehouden.

Wageningen Environmental Research aanvaardt geen aansprakelijkheid voor eventuele schade voortvloeiend uit het gebruik van de resultaten van dit onderzoek of de toepassing van de adviezen.

Wageningen Environmental Research Rapport 2920 | ISSN 1566-7197

Foto omslag: Een Akkerhommel op Rode klaver; foto Wim Ozinga 


\section{Inhoud}

$\begin{array}{ll}\text { Woord vooraf } & 5\end{array}$

$\begin{array}{ll}\text { Samenvatting } & 7\end{array}$

1

$\begin{array}{ll}\text { Introductie } & 11\end{array}$

1.1 Achtergrond 11

1.1.1 Afname aantallen en diversiteit aan bestuivende insecten 11

$\begin{array}{ll}1.1 .2 \text { Kennisimpuls bestuivers } & 11\end{array}$

1.2 Doelstelling en fasering $\quad 12$

2

Methoden

2.1 Databestanden $\quad 14$

2.1.1 Verspreidingsdata bijen en zweefvliegen 14

$\begin{array}{ll}2.1 .2 \text { Selectie verspreidingsdata } & 14\end{array}$

$\begin{array}{ll}2.1 .3 \text { Omgevingsfactoren } & 15\end{array}$

2.2 Clusteranalyses $\quad 16$

2.2.1 Overzicht van de stappen 16

2.2.2 Hiërarchische clustering van kilometerhokken 16

2.2.3 Omgrenzing clusters van kilometerhokken (landschapstypen) 17

2.2.4 Relatieve voorkeur van soorten voor landschapstypen 18

2.3 Bepaling van het belang van clusters voor bedreigde soorten en bestuivers van gewassen 18

2.3.1 Belang voor bedreigde soorten 18

2.3.2 Belang voor de belangrijkste bestuivers van gewassen 19

3 Resultaten: bijen en zweefvliegen per landschapstype $\quad 20$

3.1 Mate van aanwezigheid van bestuivers per landschapstype 20

3.1.1 Samenhang tussen omgevingsfactoren en variatie in soortensamenstelling20

$\begin{array}{ll}3.1 .2 \text { Kaart met landschapstypen } & 21\end{array}$

3.1.3 Bijen en zweefvliegen per landschapstype 23

3.2 Belang clusters voor belangrijkste bestuivers van landbouwgewassen 35

$\begin{array}{lll}3.3 & \text { Belang clusters voor bedreigde soorten } & 38\end{array}$

4.1 Gebruik van de tabellen met soorten per landschapstype 42

4.1.1 Mogelijkheden en beperkingen $\quad 42$

4.1.2 Verschillende ambitieniveaus $\quad 43$

4.2 Vervolg: Clusters als kader voor specificering ecologische randvoorwaarden 44

$\begin{array}{ll}\text { Literatuur } & \mathbf{4 5}\end{array}$

$\begin{array}{lll}\text { Bijlage } 1 & \text { Alfabetisch overzicht bijen en zweefvliegen } & 48\end{array}$ 



\section{Woord vooraf}

Via de Nationale Bijenstrategie werken het ministerie van Landbouw, Natuur en Voedselkwaliteit (LNV) en 59 maatschappelijke partners samen aan inmiddels zo'n 95 initiatieven (stand van zaken november 2018), met hetzelfde hoofddoel: in 2030 zijn bestuivers en bestuivingsdiensten in ons land duurzaam behouden en bevorderd. Drie centrale thema's waaraan wordt gewerkt, zijn het terugbrengen van voldoende leefgebied (meer aanbod van voedsel en nestelplek), een betere wisselwerking tussen natuur en landbouw en een betere imkerpraktijk.

Om deze initiatieven effectief vorm te geven, is kennis vereist. Zowel om nieuwe initiatiefnemers de juiste handvaten te bieden om hun bijdrage zo effectief mogelijk vorm te geven als om meer mensen bewust te maken van de noodzaak om bestuivende insecten te ondersteunen en de wijze waarop ook zij hun steentje kunnen bijdragen. Gedurende de komende jaren (tot en met 2021) investeert het ministerie van LNV in deze kennisbehoefte via de Kennisimpuls Bestuivers, die wordt uitgevoerd door Wageningen UR, in nauwe samenwerking met Naturalis Biodiversity Center en EIS Kenniscentrum Insecten. Meer informatie is beschikbaar via de projectwebsite: www.kennisimpulsbestuivers.nl.

Het voorliggende rapport beschrijft de eerste resultaten van een van de onderzoeksmodules binnen deze Kennisimpuls Bestuivers. Deze module richt zich op het verschaffen van inzicht in de ecologische randvoorwaarden voor bestuivende insectensoorten en in effectieve maatregelen voor het behoud en herstel van bestuivers, inclusief toetsingscriteria. Aan dit onderzoek werd behalve door Wageningen UR, Naturalis Biodiversity Center en EIS Kenniscentrum Insecten ook meegewerkt door onderzoeksbureau Ecologica.

Voor de totstandkoming van dit rapport willen we de honderden vrijwilligers bedanken die waarnemingen van bijen en zweefvliegen hebben geleverd voor het databestand van EIS. Een interne peerreview is uitgevoerd door Anne Schmidt (WENR) en Tim Faasen (Ecologica) stelde diverse foto's beschikbaar. Ten slotte willen we Annet Zweep bedanken voor de begeleiding van het project vanuit het ministerie van LNV. 


\section{Samenvatting}

Bij de bestuiving van veel voedselgewassen en wilde planten spelen bloembezoekende insecten een essentiële rol. Het gaat dan niet alleen over honingbijen, maar over een breed spectrum van soorten wilde bijen en zweefvliegen. Los van het functionele belang van bestuivende insecten, vormen ze een belangrijke component van de biodiversiteit in de Nederlandse natuur. Er zijn echter sterke aanwijzingen dat de laatste decennia zowel de aantallen als de soortendiversiteit van bestuivers sterk achteruit zijn gegaan. Via de Nationale Bijenstrategie werken het ministerie van Landbouw, Natuur en Voedselkwaliteit (LNV) en meer dan vijftig maatschappelijke partners samen met als hoofddoel: in 2030 zijn bestuivers en bestuivingsdiensten in ons land duurzaam behouden en bevorderd. Als bijdrage hieraan is voor de komende jaren een 'kennisimpuls bestuivers' in het leven geroepen, gericht op kennisontwikkeling, kennisverspreiding en vergroting van bewustwording. De doelgroep zijn actoren die een bijdrage kunnen leveren aan het behoud en bevorderen van populaties van wilde bestuivers. Initiatiefnemers voor maatregelen hebben niet altijd de benodigde kennis in huis om de inrichting en het beheer van een gebied zodanig in te vullen dat dit optimaal effect sorteert. Dit is in de praktijk ook lastig, omdat in Nederland honderden soorten wilde bijen en zweefvliegen voorkomen met elk hun specifieke wensen ten aanzien van hun leefgebied en omdat in verschillende landschapstypen verschillende soorten voorkomen of zouden kunnen voorkomen. Maatwerk is dus geboden. Om dat maatwerk efficiënt vorm te geven, is er behoefte aan een overzicht van groepen bestuivers met vergelijkbare habitateisen.

Een van de onderdelen van de kennisimpuls bestuivers richt zich op het verschaffen van meer inzicht in de ecologische randvoorwaarden van bestuivende insectensoorten en in effectieve maatregelen om hieraan tegemoet te komen. In het voorliggende rapport wordt de eerste stap van dit onderdeel beschreven waarin met clusteranalyses het voorkomen van bijen en zweefvliegen in verschillende landschapstypen in beeld is gebracht. De basis voor de analyses werd gevormd door databestanden met inventarisatiegegevens van bijen en zweefvliegen per kilometerhok, in combinatie met een GISbestand met informatie over omgevingsfactoren. Hiermee zijn clusters van kilometerhokken geïdentificeerd (landschapstypen) met een vergelijkbaar spectrum aan soorten bestuivers. Per soort geeft deze matrix een overzicht van de landschapstypen waarin de soort vooral voorkomt, waarbij veel soorten in meerdere typen voor kunnen komen. Doel van deze informatie is om snel inzicht te kunnen krijgen in de relevante soorten bestuivers die (zouden kunnen) voorkomen in een bepaalde beheersregio, om vervolgens gerichte maatregelen te kunnen nemen die aansluiten bij de eisen die deze soorten aan hun omgeving stellen. De resultaten vormen hiermee tevens de basis voor de volgende fase in deze module: het specificeren van ecologische randvoorwaarden van bestuivers ten aanzien van voedselplanten en de (micro)biotoop voor de voortplanting (met daarbij ook aangegeven welke kennishiaten er nog zijn) en het identificeren van effectieve maatregelen. Verschillende soortengroepen zullen immers andere eisen stellen en dus ook andere maatregelen vergen.

De variatie in soortensamenstelling tussen kilometerhokken blijkt voor zowel bijen als zweefvliegen vooral samen te hangen met het oppervlak natuur. $\mathrm{Er}$ is een gradiënt in soortensamenstelling aanwezig van kilometerhokken met een relatief hoog aandeel aan natuur (vaak relatief soortenrijk) naar kilometerhokken waar het landgebruik gedomineerd wordt door landbouw en/of bebouwing (meestal soortenarm). In de tweede plaats hangen verschillen sterk samen met de fysischgeografische ondergrond (fysisch-geografische regio's). Het effect van de fysisch-geografische ondergrond is vooral zichtbaar in kilometerhokken met een aanzienlijk aandeel natuur. In kilometerhokken waar het landgebruik wordt gedomineerd door landbouw of bebouwing wordt de invloed van de fysisch-geografische ondergrond overschaduwd door het intensieve landgebruik. De uiteindelijke indeling van kilometerhokken in landschapstypen is gebaseerd op fysisch-geografische regio's met extra clusters voor kilometerhokken met een hoog aandeel bebouwd gebied ('urbaan', inclusief steden, dorpen en industrieterreinen) of een hoog aandeel landbouwkundig gebruik ('agrarisch gebied'). 
Bij de interpretatie van het belang van de landschapstypen voor bestuivende insecten is onderscheid gemaakt tussen bedreigde soorten en soorten die in potentie een belangrijke rol kunnen spelen bij de bestuiving van landbouwgewassen ('dominante gewasbestuivers'). Het eerste aspect is vooral van belang voor het behoud van biodiversiteit in Nederland, terwijl het tweede aspect van belang is voor de levering van ecosysteemdiensten. Bij een vergelijking van de soorten valt het op dat beide groepen nauwelijks overlap vertonen. Beide groepen verschillen ook sterk in de mate van voorkomen in de verschillende landschapstypen waarbij vooral de verschillen in het agrarisch gebied in het oog springen.

Het merendeel van de gewasbestuiving door bijen en zweefvliegen wordt verzorgd door slechts een handjevol soorten ( $80 \%$ van de gewasbestuiving komt voor rekening van $2 \%$ van de bijensoorten). Deze dominante gewasbestuivers zijn vertegenwoordigd in alle landschapstypen, inclusief het agrarisch gebied en het urbaan gebied. Van het kleine groepje bijensoorten dat regelmatig voorkomt in intensief gebruikt agrarisch gebied, kan ruim de helft een belangrijke rol spelen bij de gewasbestuiving. Het gaat hierbij echter om een kleine subset van de potentiële gewasbestuivers. Van de 32 belangrijkste gewasbestuivende bijensoorten in Nederland komen slechts 9 soorten relatief vaak voor in intensief gebruikt agrarisch gebied. Dit zijn: Aardhommel, Veldhommel, Steenhommel, Akkerhommel, Boomhommel, Weidehommel, Tuinhommel, Rosse metselbij en Vosje. Dominante gewasbestuivers onder de zweefvliegen die relatief veel voorkomen in het agrarisch gebied zijn Snorzweefvlieg, Blinde bij, Kegelbijvlieg en Gewone driehoekzweefvlieg. In delen van het agrarisch gebied met iets meer natuurlijke elementen, zijn er naast bovengenoemde soorten nog diverse andere soorten die een belangrijke rol in de bestuiving van gewassen kunnen vervullen. Een grotere diversiteit aan bestuivers kan de opbrengst van verschillende (fruit)gewassen ten goede komen. Opvallend is dat een flink deel van de in potentie dominante gewasbestuivers een optimum heeft in niet-agrarische landschapstypes.

In vergelijking met de groep van dominante gewasbestuivers is de groep met bedreigde soorten veel omvangrijker. Ruim de helft van de in Nederland voorkomende bijensoorten en een derde deel van de zweefvliegen verkeert in de gevarenzone. Het blijkt dat vrijwel alle onderscheiden landschapstypen bedreigde soorten herbergen, zodat het in alle landschapstypen zinvol kan zijn om maatregelen te nemen voor de bevordering van bestuivers. Er zijn echter wel grote verschillen in het aantal bedreigde soorten per landschapstype waarbij het agrarisch gebied hekkensluiter is. Het landschapstype met de grootste rijkdom aan bedreigde bijensoorten is het heuvelland in Limburg, op de voet gevolgd door het rivierengebied. Indien niet gekeken wordt naar het absolute aantal soorten, maar naar het percentage ten opzichte van het totaal aantal soorten binnen het landschapstype, dan neemt het duingebied een tweede plaats in. Bij de zweefvliegen springen vooral de hogere zandgronden (op plek één) en het heuvelland er in positieve zin uit qua rijkdom aan bedreigde soorten. Ook het urbane gebied is opvallend rijk aan bedreigde soorten bijen en zweefvliegen.

In vergelijking met de andere clusters is het agrarisch gebied zeer soortenarm en wordt vooral negatief gekenmerkt door het (vrijwel) ontbreken van een groot deel van de soorten. Met name bedreigde soorten die vaak kieskeurig zijn ten aanzien van specifieke milieucondities ontbreken. Een deel van de bedreigde soorten had vroeger ook in het agrarisch gebied een ruimere verspreiding en is tegenwoordig grotendeels teruggedrongen tot natuurreservaten en gebieden met een hoog aandeel aan natuurlijke elementen. De intensivering en schaalvergroting van de landbouw hebben in veel gebieden geleid tot een vervlakking van het landschap: overal ontstond meer van hetzelfde. Dit betekent echter niet dat er geen mogelijkheden zijn om het tij te keren. De vraag is dan waar je op inzet als het gaat om effectieve maatregelen voor het bevorderen van bestuivers. Het kan nuttig zijn om hierbij onderscheid te maken tussen verschillende ambitieniveaus op basis van het landgebruik in de omgeving en de speelruimte voor aanpassingen van inrichting en beheer:

- In gebieden die gedomineerd worden door grootschalige, intensieve landbouw met weinig natuurlijke elementen kunnen eenvoudige maatregelen, zoals het inzaaien van inheemse bloemenmengsels, in potentie al gunstig zijn voor het handjevol soorten bijen en zweefvliegen in het cluster 'agrarisch gebied'. Vooral algemene generalistische soorten zullen hiervan profiteren, waaronder ook diverse belangrijke gewasbestuivers. In soortenarme gebieden kan een kleine 
vergroting van de diversiteit aan bloembezoekende insectensoorten de opbrengst van verschillende (fruit)gewassen al ten goede komen.

- Wanneer in het agrarisch gebied gekozen wordt voor een hoger ambitieniveau, dan kunnen ook soorten profiteren die iets kieskeuriger zijn en die kenmerkend zijn voor het landschapstype waarin het gebied valt. Dit leidt tot een hogere diversiteit aan (potentiële) gewasbestuivers en helpt om de oorspronkelijke bestuivende fauna van dit landschap te behouden en bevorderen, inclusief diverse bedreigde soorten. Het relevante landschapstype kan vastgesteld worden met behulp van de kaart in hoofdstuk 3.

- Veel bedreigde soorten stellen strenge eisen aan hun leefomgeving en komen vrijwel uitsluitend voor in natuurgebieden en in gebieden met een hoog aandeel aan natuurlijke elementen. Het gaat hierbij bijvoorbeeld om randvoorwaarden ten aanzien van voedselplanten, nestgelegenheid (bijen), de gastheer voor larven (broedparasieten: koekoeksbijen en enkele zweefvliegen) en de aanwezigheid van speciale microbiotopen voor de larven van zweefvliegen. Voor het behoud en herstel van deze soorten is daarom maatwerk nodig en in veel gevallen zijn voor duurzame populaties grotere gebieden vereist met mozaïeken of gradiënten van verschillende habitattypen en met voldoende ruimtelijke samenhang tussen de leefgebieden.

De onderscheiden clusters zijn gebaseerd op verspreidingsgegevens met een vrij grove resolutie. Binnen de onderscheiden clusters komen daardoor bijen en zweefvliegen voor met een breed palet aan ecologische randvoorwaarden. Het specificeren van deze randvoorwaarden, met daaraan gekoppeld vuistregels voor maatregelen, betreft een vervolgonderzoek dat momenteel gaande is. De onderscheiden landschapstypen vormen daarbij een ruimtelijk kader om in te kunnen zoomen op de relevante soorten per regio. 


\section{$1 \quad$ Introductie}

\subsection{Achtergrond}

\subsubsection{Afname aantallen en diversiteit aan bestuivende insecten}

De mondiale vraag naar voedsel zal de komende decennia sterk toenemen, terwijl er nu al veel wordt gevraagd van de draagkracht van de aarde. Zo zijn voedselproductie en -consumptie verantwoordelijk voor ongeveer een derde van de klimaatbelasting en neemt de biodiversiteit in agrarische gebieden sterk af. Dit zet tegelijk ook het voedselsysteem zelf onder druk, omdat hierdoor de natuurlijke ziekteen plaagwering achteruitgaat en bestuiving van gewassen problematisch kan worden. Bij de productie van veel van onze voedselgewassen spelen bestuivers een essentiële rol (Albrecht et al., 2012; Garibaldi et al., 2013; Kleijn et al., 2015). Het gaat dan niet alleen over de gehouden honingbijen, maar ook over de in het wild voorkomende soorten bijen en zweefvliegen. Juist een goede mix en een diversiteit aan bestuivende soorten is van belang voor de stabiliteit en kwaliteit van ons voedselsysteem. Daarnaast spelen bloembezoekende insecten een belangrijke rol bij de bestuiving van een groot deel van de wilde plantensoorten (Ollerton et al., 2011). Los van het functionele belang van bestuivende insecten, vormen ze een belangrijke component van de biodiversiteit in de Nederlandse natuur.

Er zijn sterke aanwijzingen dat de laatste decennia zowel de aantallen als de soortendiversiteit van bestuivers sterk achteruit zijn gegaan. Dit geldt zowel internationaal (Potts et al., 2010; Nieto et al., 2014; Goulson et al., 2015; Potts et al., 2015) als binnen Nederland (Biesmeijer et al., 2006; Peeters et al., 2012; Scheper et al., 2014a; Reemer, 2018). De achteruitgang van aantallen bloeiende planten, de intensivering in de landbouw en het (onjuiste) gebruik van gewasbeschermingsmiddelen worden genoemd als oorzaken, maar het relatieve belang van deze factoren is nog onvoldoende bekend (Kleijn et al., 2018).

\subsubsection{Kennisimpuls bestuivers}

Het ministerie van Landbouw, Natuur en Voedselkwaliteit (LNV) heeft samen met maatschappelijke partners de Nationale Bijenstrategie opgesteld om de diversiteit aan bestuivers in Nederland te bevorderen (ministerie van LNV 2018). Als bijdrage hieraan is voor de komende jaren een 'kennisimpuls bestuivers' in het leven geroepen, gericht op kennisontwikkeling, kennisverspreiding en vergroting van bewustwording. Belangrijk is daarbij om zowel bestaande als nieuw ontwikkelde kennis te laten aansluiten bij de praktijk. De doelgroep zijn actoren die een bijdrage kunnen leveren aan het behoud en bevorderen van wilde bestuivers. Een belangrijke doelstelling is het faciliteren van de doelgroep bij het op efficiënte wijze vormgeven van hun bijdrage aan het behoud en bevorderen van bestuivers.

De kennisimpuls bestuivers richt zich op vier projectdoelen:

1. Het zo goed mogelijk stimuleren en faciliteren van de doelgroepen bij het op efficiënte wijze vormgeven van hun bijdrage aan het behoud en bevorderen van populaties van wilde bestuivers, door de daarvoor benodigde wetenschappelijke kennis met hen te delen.

2. Leren van zowel de vele reeds lopende als nieuw op te starten initiatieven voor het behoud en herstel van populaties van bestuivers, door na te gaan welke factoren tot succes leiden en hoe huidige knelpunten op te lossen.

3. Het leveren van een bijdrage aan het toetsen van de mate waarin nieuw vorm te geven initiatieven, gericht op habitatverbetering of duurzamere gewasbescherming, daadwerkelijk resulteren in een verbetering van het behoud en bevorderen van bestuivers.

4. Meer inzicht generen in de mate waarin generieke maatregelen voor bestuivers een bijdrage (kunnen) leveren aan de bescherming van de zeldzamere (bedreigde) soorten. 
Centraal in dit onderzoeksprogramma staan praktijknetwerken op verschillende schaalniveaus waarin initiatiefnemers en wetenschappers samenwerken met als motto samen kennis delen, implementeren en verder leren. Aanvullend onderzoek richt zich onder meer op het in beeld brengen van succesfactoren en knelpunten bij initiatieven ter bevordering van bestuivers, het formuleren van concrete handvaten en randvoorwaarden voor efficiënte inrichting en beheer van nieuw leefgebied voor bestuivers, inclusief zeldzamere soorten. Het onderzoeksprogramma heeft een looptijd van meerdere jaren en dit rapport beschrijft de resultaten van de eerste fase van een van de onderdelen. Een nadere toelichting van het project en de samenhang tussen de verschillende onderdelen is te vinden op de website www.kennisimpulsbestuivers.nl.

\subsection{Doelstelling en fasering}

\section{Algemene doelstelling}

Het voorliggende rapport maakt deel uit van een projectonderdeel dat zich richt op het verschaffen van inzicht in de ecologische randvoorwaarden voor bestuivende insectensoorten en in effectieve maatregelen voor het behoud en herstel van bestuivers, inclusief toetsingscriteria. Initiatiefnemers voor maatregelen ter bevordering van bestuivers, met name terreinbeheerders, collectieven voor agrarisch natuur- en landschapsbeheer en lokale overheden (gemeente en provincie) hebben niet altijd de benodigde kennis in huis om de inrichting en beheer van een specifiek gebied zodanig in te vullen dat deze optimaal effect sorteert. Dit is in de praktijk lastig, omdat er honderden soorten bestuivers voorkomen met elk hun specifieke wensen ten aanzien van hun leefgebied en omdat in verschillende landschapstypen verschillende soorten voorkomen of zouden kunnen voorkomen. Maatwerk is dus geboden, afhankelijk van de lokaal voorkomende doelsoorten. In het kader van de Bijenstrategie is het dan ook waardevol om initiatiefnemers duidelijke vuistregels te kunnen bieden voor inrichting en beheer van maatregelen gericht op specifieke groepen bestuivers. Vervolgens is het wenselijk om de resultaten van de uitgevoerde initiatieven toetsbaar te kunnen maken. Dit vereist enerzijds duidelijke toetsingscriteria (indicatoren voor de effectiviteit van initiatieven voor het herstel van populaties van bloembezoekende insecten) en anderzijds een zo eenduidige mogelijke werkwijze voor effectmeting.

De doelstelling van deze module is het verschaffen van inzicht in:

- Welke soorten vooral voorkomen in welk landschapstype (focus van deze rapportage);

- De ecologische randvoorwaarden van bijen en zweefvliegen ten aanzien van voedselplanten en de (micro)biotoop voor voortplanting (met daarbij ook aangegeven welke kennishiaten er nog zijn);

- Effectieve inrichtings- en beheermaatregelen voor het bevorderen van bestuivers, inclusief zeldzamere soorten (vuistregels voor inrichting en beheer), toegespitst op ter plaatse relevante soorten;

- De geschiktste meetstrategie om de effectiviteit van de uitgevoerde initiatieven te toetsen.

De activiteiten binnen deze module zijn opgedeeld in drie opeenvolgende stappen:

1. Clusteren van kilometerhokken op basis van het soortenspectrum aan bestuivers (deze rapportage);

2. Specificeren van ecologische randvoorwaarden en maatregelen om aan deze randvoorwaarden tegemoet te komen (2018 en 2019);

3. Ontwikkelen toetsingskader (2020).

Stap 1: Overzicht relevante soorten per landschapstype

In Nederland komen ongeveer 350 soorten wilde bijen (hommels en solitaire bijen) en 330 soorten zweefvliegen voor, met elk hun specifieke wensen ten aanzien van hun leefgebied (Reemer et al., 2009; Peeters et al., 2012). Bij mensen die betrokken zijn bij de planning en uitvoering van inrichtings- en beheermaatregelen om bestuivers te bevorderen, is er daarom behoefte aan een overzicht van groepen bestuivers met vergelijkbare habitateisen. Voor veel zeldzamere soorten zijn de ecologische randvoorwaarden (en de daarmee samenhangende eigenschappen) echter nog onvoldoende bekend. Als een eerste pragmatische stap is daarom een clusteranalyse uitgevoerd waarin de verspreidingspatronen van bijen en zweefvliegen geanalyseerd zijn. Hiermee worden clusters van kilometerhokken geïdentificeerd met een vergelijkbaar spectrum aan soorten bestuivers. 
Het resultaat van deze analyse is een matrix van clusters (landschapstypen) met per landschapstype een overzicht van kenmerkende soorten. Per soort geeft deze matrix een overzicht van de landschapstypen waarin de soort vooral voorkomt, waarbij veel soorten in meerdere landschapstypen kunnen voorkomen. Met behulp van deze informatie kan de gebruiker snel inzoomen op de relevante soorten die in zijn of haar beheersregio zouden kunnen voorkomen. Verder is het belang van de clusters bepaald voor bedreigde soorten die opgenomen staan op de Rode Lijst en voor soorten die in potentie bij kunnen dragen aan de bestuiving van landbouwgewassen. Deze twee benaderingen geven informatie over geheel verschillende aspecten. Het eerste aspect is vooral van belang voor het behoud van biodiversiteit in Nederland, terwijl het tweede aspect van belang is voor de levering van ecosysteemdiensten. Ten slotte biedt de tabel met kenmerkende soorten per landschapstype een basis voor de specificering van ecologische randvoorwaarden en maatregelen in stap 2.

\section{Afbakening}

- De focus van deze module ligt op kennis met betrekking tot twee groepen bestuivers: wilde bijen (Hymenoptera, Apidae s.I.) en zweefvliegen (Diptera, Syrphidae). Het gaat hierbij niet alleen om soorten die bijdragen aan de bestuiving van gewassen, maar om het hele soortenspectrum aan bijen en zweefvliegen, inclusief zeldzamere (bedreigde) soorten. In kennis over de honingbij (Apis mellifera) wordt reeds voorzien via enkele andere onderzoeksprogramma's, waaronder de 'Honingbij surveillance'. Naast wilde bijen en zweefvliegen zijn er nog andere insectengroepen die bij kunnen dragen aan de bestuiving van landbouwgewassen en wilde planten (o.a. vlinders, wespen, kevers, wolzwevers en diverse groepen vliegen), maar deze blijven hier buiten beschouwing.

- Een bijdrage aan de beoordeling van het succes van de Bijenstrategie zal worden geleverd door het vergroten van de toetsbaarheid van de effectiviteit van maatregelen (definiëren van succesfactoren, scheppen van een toetsingskader) en door een 'vinger aan de pols' te houden bij een selectie van initiatieven (in andere modules). Gezien het gelijktijdige startmoment en de beperkingen qua loopduur en omvang van het project, kan niet worden voorzien in een integrale en landsdekkende toetsing van de mate van doelbereik van de Bijenstrategie.

- Gezien de sterke raakvlakken tussen maatregelen voor behoud en herstel van populaties van bestuivers en maatregelen voor verduurzaming van de gewasbescherming, wordt bij de verdere uitwerking gestreefd naar afstemming en samenwerking met het zusterproject 'groene gewasbescherming'. Vooral de larven van diverse soorten zweefvliegen kunnen hierbij een nuttige rol vervullen. 


\section{$2 \quad$ Methoden}

\section{$2.1 \quad$ Databestanden}

\subsubsection{Verspreidingsdata bijen en zweefvliegen}

De basis voor de clusteranalyses wordt gevormd door databestanden met inventarisatiegegevens van wilde bijen en zweefvliegen beheerd door EIS Kenniscentrum Insecten. Deze databestanden omvatten waarnemingen verspreid over heel Nederland en bestrijken een periode van ruim honderd jaar. Ook de (gevalideerde) gegevens uit Waarneming.nl zijn in deze bestanden opgenomen.

Achtergrondinformatie over de databestanden is te vinden in de boeken De Nederlandse bijen (Peeters et al., 2012) en De Nederlandse zweefvliegen (Reemer et al., 2009).

Voor beide soortgroepen is gebruikgemaakt van data uit de periode 2002-2016 met een resolutie van $1 \mathrm{~km}^{2}$. Vergeleken met een eerdere analyse van verspreidingspatronen van onder andere zweefvliegen, sprinkhanen en libellen door Schouten et al. (2010), waarbij gebruikgemaakt is van hokken van vijf bij vijf kilometer (dus 25 keer zo groot) en een tijdsspanne van ruim honderd jaar, is dit een relatief hoge ruimtelijke en temporele resolutie van de verspreidingsdata. Het nadeel van een relatief korte periode is dat hiermee informatie gemist wordt over soorten die zeer zeldzaam zijn en/of soorten met een sterke achteruitgang. Het voordeel is dat de resultaten actueler zijn en dat het daardoor beter mogelijk is om de gegevens te koppelen met recente informatie over omgevingsvariabelen. Daarnaast sluit deze periode aan bij de actuele periode zoals die gehanteerd wordt in de nieuwe Rode Lijst van de Nederlandse bijen (zie § 3.3).

Omdat er grote verschillen zijn tussen kilometerhokken in de onderzoeksintensiteit (sampling intensiteit), is per soort alleen informatie gebruikt over de aan- of afwezigheid in de onderzoeksperiode en niet over de mate van voorkomen (abundantie). De ruimtelijke patronen van onderzoeksintensiteit vertonen bovendien duidelijke verschillen tussen de databestanden voor bijen en zweefvliegen. Bij een gezamenlijke analyse kan dit de patronen verstoren, zodat ervoor gekozen is om de gegevens van beide groepen apart te bewerken en analyseren. Wel is er bij de uitwerking van de clusters gekozen voor een indeling die zo goed mogelijk recht doet aan beide groepen (zie § 2.2.3).

\subsubsection{Selectie verspreidingsdata}

\section{Selectie kilometerhokken}

Omdat de resultaten van clusteranalyses gevoelig zijn voor onvolledige sampling, is de dataset gefilterd op basis van het aantal waarnemingsdata en/of het aantal waargenomen soorten. Voor de verdere analyses is daarom gewerkt met een relatief strenge selectie van kilometerhokken. Zowel voor bijen als voor zweefvliegen zijn alleen hokken geselecteerd met $\geq 2$ bezoekdata en/of $\geq 10$ records. Voor zweefvliegen zijn aanvullend nog hokken geselecteerd met $\geq 3$ soorten. Dit resulteerde in een bestand met 2082 kilometerhokken voor bijen en 3906 kilometerhokken voor zweefvliegen. Hierbij moet in het achterhoofd gehouden worden dat hokken gedomineerd door grootschalige intensieve landbouw waarschijnlijk ondervertegenwoordigd zijn in de dataset.

\section{Selectie soorten}

Bij de analyse zijn soorten buiten beschouwing gelaten indien ze in de periode 2002-2016 in minder dan vijf kilometerhokken zijn waargenomen. Dit geldt dus ook voor soorten die vroeger algemener voorkwamen en tegenwoordig (vrijwel) uit Nederland verdwenen zijn. Verspreidingsgegevens van de Europese honingbij (Apis mellifera) zijn niet in de analyse meegenomen, omdat het databestand van EIS zich richt op wilde soorten en van deze gedomesticeerde soort is de verspreidingsinformatie in het databestand daardoor onvolledig (Peeters et al., 2012). Doordat vrijwel overal in het land bijenkasten staan, komt deze soort in geheel Nederland algemeen voor. 
Voor enkele zweefvliegen-taxa zijn in het basisbestand records aanwezig voor de soort in strikte zin (sensu stricto) en in ruimere zin (een combinatie van verwante en lastig te onderscheiden soorten). In dat geval zijn de records van de soorten in strikte zin samengenomen met de records van de soort in ruime zin (met per gridcel nog steeds een maximum '1'). De soorten in strikte zin zijn bij de analyse buiten beschouwing gebleven. Het gaat om de volgende taxa: Cheilosia albitarsis / ranunculi, Cheilosia canicularis / himantopus, Leucozona lucorum / inopinata, Platycheirus scutatus / splendidus / aurolateral, Xanthogramma pedissequum s.I. De uiteindelijke selectie omvat 254 soorten bijen en 223 soorten zweefvliegen.

\subsubsection{Omgevingsfactoren}

Voor de ecologische interpretatie van de verspreidingspatronen is gebruikgemaakt van een GISbestand met per kilometerhok informatie over de fysisch-geografische ondergrond, landgebruik en natuurtype.

\section{Fysisch-geografische ondergrond}

Op landschapsschaal worden de dominante abiotische condities (actueel of potentieel) voor een belangrijk deel bepaald door de geomorfologie (substraat en reliëf), waterhuishouding en bodemkenmerken van een gebied. Met betrekking tot de fysisch-geografische ondergrond van het landschap is voor deze studie gebruikgemaakt van een hiërarchische indeling in fysisch-geografische regio's, fysisch-geografische series en fysiotopen zoals beschikbaar in het informatiesysteem SynBioSys (De Waal, 1995, 2007; Schaminée et al., 2007). Op het laagste niveau worden fysiotopen onderscheiden op basis van abiotische factoren die relevant zijn voor verschillen in plantengroei. Fysiotopen zijn daarbij te definiëren als landschappelijke eenheden met een min of meer gelijke abiotiek (De Waal 2007). Op het hoogste hiërarchische niveau is een fysisch-geografische regio een gebied dat overeenkomt in het door geo(morfo)logische processen bepaalde moedermateriaal (De Waal, 2007; Kemmers et al., 2011).

In een kilometerhok kunnen meerdere fysiotopen voorkomen en om deze heterogeniteit in beeld te brengen, is een extra veld toegevoegd met het aantal fysisch-geografische eenheden per kilometerhok (op het niveau van fysisch-geografische series en fysiotopen). Voor heterogene hokken is de mate van binding van soorten aan specifieke landschapstypen niet goed te kwantificeren. Deze heterogeniteit kan mogelijk ook een belangrijke ecologische randvoorwaarde zijn, doordat sommige soorten afhankelijk zijn van specifieke combinaties van landschapstypen in de vorm van macro-gradiënten of mozaïeken van landschapstypen (Weeda et al., 2006; Meyer et al., 2009).

\section{Landgebruik en natuurtype}

In Nederland heeft het menselijk landgebruik een sterke invloed gehad op de abiotische en biotische condities. In deze studie is gebruikgemaakt van globale informatie over landgebruik en natuurtype op basis van de Basiskaart Natuur versie 2004 met aanvullingen (Kramer et al., 2007; Kramer et al., 2013). De Basiskaart Natuur (BKN) is een GIS-bestand waarin het areaal landgebruik en natuurgebied in Nederland opgenomen is. Het bestand is gemaakt met behulp van diverse bronbestanden zoals die bij de Geodesk van Wageningen Environmental Research aanwezig zijn. Er is gewerkt met een bestand waarin de data geaggregeerd zijn op het niveau van kilometerhokken, met per kilometerhok het aantal hectares dat valt onder een bepaalde klasse landgebruik (inclusief natuurtypen). Hierbij is gebruikgemaakt van de volgende hoofdklassen: natuur, water, landbouw, en bebouwd gebied (inclusief infrastructuur). Natuur is verder onderverdeeld in de volgende 'natuurtypen': productiegrasland, natuurgraslanden, heide, bos, rietmoeras, stuifzanden en duinen. Het GIS-bestand is aangevuld met informatie uit het Geografisch Informatiesysteem Agrarische Bedrijven (GIAB). Hierin zijn gegevens opgenomen van landbouwbedrijven in Nederland die meedoen aan de jaarlijkse landbouwtelling van het Centraal Bureau voor de Statistiek en de Rijksdienst voor Ondernemend Nederland (Gies et al., 2015). 


\section{$2.2 \quad$ Clusteranalyses}

\subsubsection{Overzicht van de stappen}

Om te komen tot een overzicht van de relevante soorten bijen en zweefvliegen per landschapstype, zijn de verspreidingsgegevens geanalyseerd met behulp van clusteranalyses en ordinaties. De opeenvolging van stappen (workflow) wordt samengevat in Figuur 1 en de technische details worden in de tekst nader toegelicht. Ten behoeve van de leesbaarheid worden de technische tussenresultaten in dit hoofdstuk beknopt beschreven. In hoofdstuk drie worden alleen de belangrijkste eindresultaten beschreven.

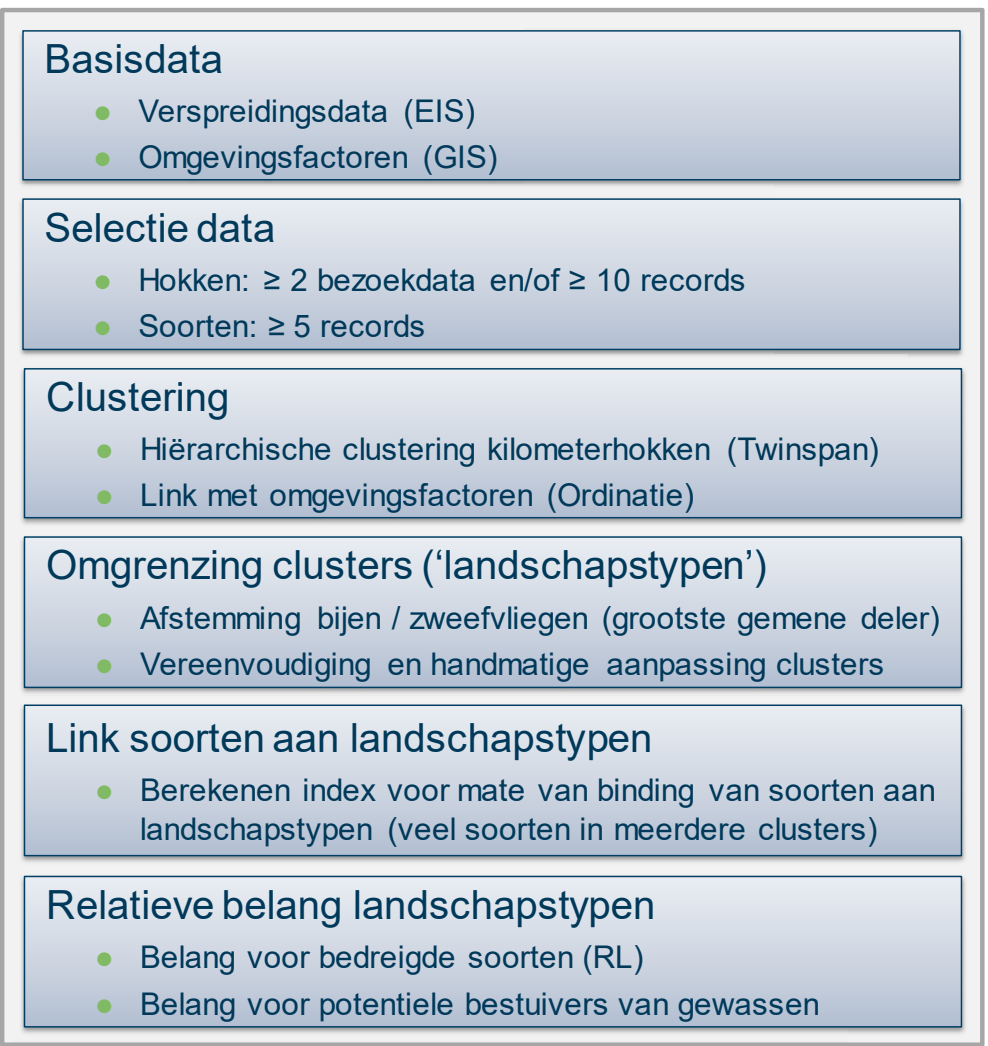

Figuur 1 Samenvatting van de stappen (workflow) bij de bepaling van het spectrum aan wilde bijen en zweefvliegen per landschapstype.

\subsubsection{Hiërarchische clustering van kilometerhokken}

\section{Clusteranalyse met Twinspan}

Clusteranalyses zijn een hulpmiddel om waarnemingen in te delen in groepen (clusters) op basis van een rekenkundig algoritme. Er zijn verschillende technieken en softwaretools om gegevens te clusteren en voor ons doel is gekozen voor een 'Two-way indicator species analysis' via het programma Twinspan for Windows versie 2.3 (Hill \& Šmilauer, 2005). Twinspan wordt veel gebruikt voor de analyse van levensgemeenschappen en resulteert in een hiërarchische indeling in clusters. Dit heeft als voordeel dat het aantal te onderscheiden groepen flexibel is. Een tweede voordeel is dat zowel de locaties (hier kilometerhokken) als de soorten geclusterd worden, waardoor de interpretatie eenvoudiger wordt.

De clustering met behulp van Twinspan is gebaseerd op een iteratieve procedure m.b.v. drie stappen. Eerst wordt een primaire ordinatie uitgevoerd, waarbij de ordinatieas in tweeën wordt gedeeld op basis van de centroïd. De meest differentiërende soorten worden in een tweede stap gebruikt voor een verdere verfijning. Deze soorten krijgen een hoger gewicht, zodat de verschillen worden uitvergroot. Deze polarisatie is minder sterk indien er veel algemene soorten aanwezig zijn zonder duidelijke voorkeur. Ten slotte worden in een derde stap de locaties en de soorten (inclusief de grensgevallen) 
toegewezen aan clusters. Deze twee groepen worden vervolgens onafhankelijk van elkaar weer gesplitst in twee groepen, zodat een hiërarchische indeling in groepen ontstaat.

Bij de clustering van de verspreidingsdata werd alleen gebruikgemaakt van informatie over de aan- of afwezigheid van soorten in gridcellen. Er wordt bij de clustering van uitgegaan dat het ontbreken van een waarneming in een kilometerhok betekent dat een soort in de betreffende periode niet voorkwam. Bij de clustering is gebruikgemaakt van de volgende instellingen: Geen pseudospecies; maximaal aantal splitsingen: 5; minimale groepsgrootte voor splitsing: 5; maximum aantal indicator soorten voor de beschrijving van een splitsing: 10. In onze analyses lag de focus op de indeling van de kilometerhokken om te komen tot landschapstypen met een overeenkomstig spectrum aan soorten.

\section{Multivariate analyse met omgevingsfactoren}

De resultaten van clusteranalyses moeten gezien worden als een hulpmiddel, waarbij vaak aanvullende analyses nodig zijn om de praktische bruikbaarheid te vergroten (McCune et al., 2002; Legendre \& Legendre, 2012). Zo hebben clusteranalyses vaak moeite met de analyse van complexe en meervoudige gradiënten, waarbij een deel van de datapunten niet goed aan een cluster toegewezen kan worden. In aanvulling op de clusteranalyse is daarom gebruikgemaakt van ordinaties (CCA: Canonical Correspondence Analysis) met behulp van Canoco 5 (Ter Braak \& Šmilauer, 2012). Hierbij werden naast de verspreidingsgegevens ook data over omgevingsfactoren in de analyses meegenomen. Voorafgaand aan de analyse zijn de omgevingsvariabelen gecentreerd en gestandaardiseerd (met voor alle variabelen een gemiddelde van 0 en een standaarddeviatie van 1), zodat ze onderling beter vergelijkbaar zijn. De resultaten van een CCA geven inzicht in de mate waarin de variatie in soortensamenstelling langs gradiënten samenhangt met omgevingsfactoren. In vergelijking met clusteranalyses geeft dit een genuanceerder, maar complexer multidimensionaal beeld.

Per omgevingsfactor is de significantie van de samenhang met de variatie in soortensamenstelling getest ten opzichte van een randomverdeling van de waarnemingen over de plots met behulp van Monte-Carlo permutatietests met 1000 permutaties. Hiermee wordt een parameter berekend, de Pseudo-F, die een maat geeft voor de hoeveelheid variatie in de soortensamenstelling die verklaard kan worden met behulp van de geteste variabele in verhouding tot de onverklaarde (residuele) variatie. Deze maat is vergelijkbaar met de veel gebruikte F-ratio in regressiemodellen of ANOVA, maar dan in een multivariate uitvoering. Het gaat bij de hier gebruikte analyses om het marginale effect van de variabelen, zonder dat rekening gehouden wordt met andere (co)variabelen. Dit laatste vergt aanvullende analyses en valt buiten het kader van dit project.

\subsubsection{Omgrenzing clusters van kilometerhokken (landschapstypen)}

Van de onderzochte omgevingsfactoren met een relatief sterke relatie met de verspreidingspatronen van bijen en zweefvliegen (zie § 3.1.1) wordt de grootste gemene deler gevormd door de fysischgeografische ondergrond (fysisch-geografische regio's) en het type landgebruik (het relatieve aandeel natuur, landbouw en bebouwd gebied). Het effect van de fysisch-geografische ondergrond is met name zichtbaar in kilometerhokken met een aanzienlijk aandeel natuur. In kilometerhokken waar het landgebruik wordt gedomineerd door landbouw of bebouwing is de invloed van de fysisch-geografische ondergrond minder duidelijk.

Voor de uiteindelijke indeling is gekozen voor een vrij globale indeling met een beperkt aantal duidelijk gedifferentieerde clusters (zie Tabel 2). De clusters ('landschapstypen') zijn grotendeels gebaseerd op de fysisch-geografische ondergrond (op het hiërarchische niveau van fysisch-geografische regio's).

Daarnaast zijn extra clusters onderscheiden voor hokken met een hoog aandeel bebouwd gebied ('urbaan', inclusief steden, dorpen en industrieterreinen) of een hoog aandeel landbouwkundig gebruik ('agrarisch gebied'). Binnen deze laatste twee clusters is voor bijen nog onderscheid gemaakt in een soortenarme en een soortenrijke subgroep op basis van de resultaten van de Twinspan-analyse (niet weergegeven op de kaart, omdat deze indeling niet vlakdekkend weergegeven kan worden). In het agrarisch gebied kan de soortenrijkere subgroep gezien worden als een overgangsvorm naar de landschapstypen op basis van fysisch-geografische regio's. Bij de clusters die onderscheiden zijn op basis van de fysisch-geografische ondergrond gaat het om kilometerhokken die niet worden gedomineerd door landbouwkundig gebruik en/of bebouwing. Een voordeel van een expliciete koppeling met 
omgevingsfactoren is dat het hiermee mogelijk wordt om de potentiële ruimtelijke verspreiding van de clusters vlakdekkend op een kaart weer te geven, inclusief veel kilometerhokken met geen of nauwelijks informatie over de soortensamenstelling.

\subsubsection{Relatieve voorkeur van soorten voor landschapstypen}

Clusteranalyses met behulp van Twinspan resulteren in een indeling van zowel locaties (hier landschapstypen op basis van overeenkomstige kilometerhokken) als van soorten in clusters. De clusters van soorten zijn echter vaak te grof voor praktische toepassingen. Dit hangt samen met het feit dat er in de praktijk meestal geen sprake is van strak omgrensde groepen van soorten, maar van graduele overgangen waarbij veel soorten voorkomen in meerdere clusters. Het is dan nuttiger om informatie te hebben over de mate van aanwezigheid van soorten in verschillende clusters van kilometerhokken. Ook bij soorten die voorkomen in meerdere clusters zijn er vaak wel duidelijke verschillen in de mate van aanwezigheid. Veel indices voor de mate van aanwezigheid van soorten in clusters zijn echter gevoelig voor verschillen in de indeling van de overige clusters (Dufrene \& Legendre, 1997; Tichy \& Chytry, 2006; De Caceres et al., 2010). Er is daarom gekozen voor een meer robuuste index voor de relatieve mate van aanwezigheid in clusters (landschapstypen), de 'Phi coefficient of association' (Tichy \& Chytry, 2006). Hierbij wordt een resampling-procedure gebruikt waarbij gecorrigeerd wordt voor verschillen in omvang van de clusters. Deze $\Phi$-coëfficiënt geeft een maat voor de relatieve voorkeur van soorten voor verschillende landschapstypen op een schaal van -1 tot 1 . Een waarde groter dan nul geeft aan dat de soort een relatieve voorkeur heeft voor een bepaald cluster (dit kan gelden voor meerdere clusters). De maximale waarde (1) geldt voor het theoretische geval dat een soort in alle hokken van een cluster voorkomt, en in geen enkel ander hok, terwijl voor de minimale waarde $(-1)$ het omgekeerde geldt. Het resultaat van de analyses is een matrix van landschapstypen (clusters) met per landschapstype een overzicht van soorten waarvan een relatief groot deel van de waarnemingen binnen dit cluster valt. Ten behoeve van de leesbaarheid zijn in de tabellen met resultaten alleen $\Phi$-waarden $\geq 0$ weergegeven. In de matrix betekenen lege cellen niet per se dat de soort niet voorkomt, maar dat de soort een voorkeur heeft voor andere landschapstypen.

\subsection{Bepaling van het belang van clusters voor bedreigde soorten en bestuivers van gewassen}

\subsubsection{Belang voor bedreigde soorten}

Voor het inschatten van het belang van de onderscheiden landschapstypen voor bedreigde soorten is voor bijen gebruikgemaakt van de recent gepubliceerde Rode Lijst van de Nederlandse bijen (Reemer, 2018). Deze lijst is opgesteld in opdracht van het ministerie van LNV en op 30 april 2018 gepubliceerd in de Staatscourant. Voor de lijst zijn de verspreidingsgegevens geanalyseerd van 331 soorten wilde bijen die zich in Nederland regelmatig voortplanten en zijn per soort de talrijkheid en trend bepaald. Bijensoorten zijn aangemerkt als Rode-Lijstsoort wanneer ze aan zowel het criterium trend (achteruitgang) als het criterium zeldzaamheid voldoen, of in hoge mate aan een van deze criteria. Voor het bepalen van trends per soort is het aantal atlasblokken $(5 \times 5 \mathrm{~km})$ waarin de soort is waargenomen in de periode 2002-2016 vergeleken met de periode 1900-1969. Op basis van de mate van bedreiging worden de volgende Rode-Lijstcategorieën onderscheiden (met tussen haakjes het aantal soorten): gevoelig (25), kwetsbaar (38), bedreigd (42), ernstig bedreigd (30). Daarnaast is er nog een categorie 'verdwenen' (46 soorten) voor inheemse soorten die uit Nederland verdwenen zijn, maar deze categorie wordt hier buiten beschouwing gelaten. De overige 150 beoordeelde soorten zijn geplaatst in de categorie 'Thans niet bedreigd'. De Rode Lijst omvat dus 181 bijensoorten, dat wil zeggen ruim de helft (55\%) van de beschouwde soorten. Voor een uitgebreidere toelichting van de methode en de resultaten wordt verwezen naar het basisrapport voor de Rode Lijst Bijen (Reemer, 2018).

Voor een inschatting van het belang van verschillende landschapstypen voor bedreigde bijen is per cluster bepaald hoeveel soorten opgenomen zijn in de Rode Lijst (alle vier categorieën samen). Daarnaast is per cluster ook het aantal soorten van de twee zwaarste categorieën (Bedreigd en Ernstig bedreigd) bepaald. Bij het bepalen van de relatieve voorkeur van soorten voor landschapstypen zijn 
alleen soorten meegenomen met minimaal 5 records in de onderzoeksperiode. Dit betekent dat zeer zeldzame en verdwenen Rode Lijst-soorten niet meegenomen zijn in de analyse. In totaal omvat de analyse 103 van de in totaal 181 Rode Lijst-soorten. Verder moet er bij de interpretatie van de resultaten rekening mee gehouden worden dat alleen soorten met een relatieve voorkeur voor het betreffende cluster meetellen (soorten met een Phi coefficient of association $>0$ ). Naast deze soorten kunnen dus ook andere bedreigde soorten voorkomen, maar deze soorten hebben hun optimum in andere landschapstypen.

Voor zweefvliegen is geen officiële Rode Lijst beschikbaar en hiervoor is gebruikgemaakt van gegevens in het boek 'De Nederlandse zweefvliegen' (Reemer et al., 2009). Ook hierbij is de inschatting van de mate van bedreiging per soort gebaseerd op basis van trend en zeldzaamheid, maar de criteria en methode wijken af van de Rode Lijst van de Nederlandse bijen. De lijst met bedreigde wilde bijen en zweefvliegen zijn daardoor niet goed vergelijkbaar.

\subsubsection{Belang voor de belangrijkste bestuivers van gewassen}

De verschillende soorten bijen en zweefvliegen verschillen sterk in hun potentiële bijdrage aan de bestuiving van landbouwgewassen. Vooral voor wilde bijen is hier veel onderzoek naar verricht en hieruit komt het beeld naar voren dat slechts een beperkt aantal bijensoorten de bulk van de gewasbestuiving verzorgt. Uit een wereldwijde meta-analyse van de resultaten van 90 studies bleek dat $80 \%$ van de gewasbestuiving voor rekening komt van slechts $2 \%$ van de bijensoorten (Kleijn et al., 2015). Dit betekent niet dat aanwezigheid van een of enkele soorten in een gewasperceel afdoende is: voor verschillende (fruit)gewassen is aangetoond dat een grotere diversiteit aan bloembezoekende bestuivers de opbrengst ten goede komt (De Groot et al., 2015; De Groot et al., 2016; Fijen et al., 2018). De lijst met belangrijkste gewasbestuivers biedt echter wel enig houvast voor een analyse waar in ons land de belangrijkste bestuivende soorten zich momenteel bevinden, en daarmee voor specificering van maatregelen.

De door Kleijn et al. (2015) geïdentificeerde belangrijkste of 'dominante' gewasbestuivende bijensoorten zijn daarom als uitgangspunt genomen voor het inschatten van het belang van de onderscheiden landschapstypes voor de belangrijkste gewasbestuivers. Dominante gewasbestuivende soorten zijn hierbij gedefinieerd als bijensoorten die in minstens één studie-gewas-jaar-combinatie in Europa $>5 \%$ van het totaal aantal bloembezoekende wilde bijen in het gewas vormen. Het gaat dus om de potentie van soorten om een belangrijke bijdrage te leveren aan gewasbestuiving. Of dit in een bepaald gebied ook daadwerkelijk gebeurt, hangt mede af van het gewas, diverse omgevingsfactoren en de talrijkheid van de soort in de omgeving (minder talrijke soorten dragen minder bij). In de lijst staan enkele soorten die elders in Europa een belangrijke rol spelen bij gewasbestuiving, maar die in Nederland (nog) zeldzaam zijn. De volgende drie soorten zijn in de onderzoeksperiode waargenomen in minder dan 50 kilometerhokken: Lookmaskerbij (Hylaeus punctulatissimus), Roodbruine groefbij (Lasioglossum xanthopus) en Breedbandgroefbij (Halictus scabiosae). Daarnaast kunnen de soorten verschillen in de efficiëntie van bestuiving (zie § 3.2). Zo is de Lookmaskerbij vrijwel kaal en zo klein dat ze stuifmeelhokjes van grotere bloemen vaak apart bevliegt en dan nauwelijks in contact komt met de stempels. Met andere woorden: met het bepalen van de meest abundante bloembezoekers heb je waarschijnlijk wel de in potentie belangrijkste bestuivers te pakken, maar niet elke abundante bezoeker is een goede bestuiver. De hier gebruikte lijst moet daarom gezien worden als indicatie.

Voor zweefvliegen is een dergelijk systematisch overzicht niet beschikbaar. Om dominante gewasbestuivende zweefvliegsoorten aan te kunnen wijzen, is daarom gebruikgemaakt van enkele Nederlandse onderzoeken naar de bestuiving van gewassen (Scheper et al., 2011; Reemer \& Kleijn, 2012; De Groot et al., 2015; De Groot et al., 2016) en voorlopige resultaten van inventarisaties in meerdere praktijknetwerken binnen de Kennisimpuls Bestuivers (Scheper et al., in prep.). Het gaat hierbij om onderzoek gedaan bij bedrijven met appel, peer, aardbei, blauwe bes en koolzaad. Net als bij de bijensoorten zijn dominante gewasbestuivende zweefvliegsoorten hierbij gedefinieerd als soorten die in ten minste één studie-gewas-jaar combinatie $>5 \%$ van het bloembezoek van alle zweefvliegen op het gewas voor hun rekening nemen. 


\section{Resultaten: bijen en zweefvliegen per landschapstype}

\subsection{Mate van aanwezigheid van bestuivers per landschapstype}

\subsubsection{Samenhang tussen omgevingsfactoren en variatie in soortensamenstelling}

Er zijn grote verschillen tussen kilometerhokken in de soortensamenstelling. Met behulp van ordinaties is gekwantificeerd in welke mate de belangrijkste gradiënten in soortensamenstelling samenhangen met omgevingsfactoren (Tabel 1 ). De kolommen met het relatieve belang voor bijen en zweefvliegen geeft de 'pseudo- $F^{\prime}$ als indicatie van de relatieve hoeveelheid variatie in de data die door de geteste variabele verklaard kan worden in verhouding tot de onverklaarde (residuele) variatie. Hoe groter de pseudo- $F$, hoe meer samenhang er is met de variatie in soortensamenstelling. Bij de interpretatie van de gegevens moet bedacht worden dat een sterke samenhang niet per se betekent dat er een oorzakelijk verband is, omdat milieufactoren onderling vaak sterk samenhangen (multicollineariteit).

De variatie in soortensamenstelling tussen de kilometerhokken hangt voor beide groepen vooral samen met het oppervlak natuur (en diverse daarmee gecorreleerde factoren zoals het oppervlak bos, heide en stuifzand). Uit de ordinaties blijkt dat de eerste ordinatieas wordt gedomineerd door een gradiënt van kilometerhokken met een relatief hoog aandeel aan natuur, naar kilometerhokken waar het landgebruik gedomineerd wordt door landbouw en/of bebouwing. In de tweede plaats hangen verschillen sterk samen met de fysisch-geografische ondergrond (fysisch-geografische regio's, CCA-as 2 en 3). De differentiatie van kilometerhokken op CCA-as 2 en 3 treedt vooral op in het deel van de gradiënt op CCA-as 1, waar het aandeel natuur relatief hoog is. Dit wijst erop dat het effect van de fysisch-geografische ondergrond op bestuivers met name tot uiting komt in kilometerhokken met een aanzienlijk aandeel natuur. De fysisch-geografische regio's verschillen onderling sterk in het spectrum aan soorten dat ze herbergen (zie Tabel 3 en 4), maar voor bijen is er relatief weinig differentiatie in het laagveengebied. In kilometerhokken waar het landgebruik wordt gedomineerd door landbouw of bebouwing is de invloed van de fysisch-geografische ondergrond minder duidelijk.

Tabel 1 Overzicht van de samenhang van enkele omgevingsfactoren met de variatie in soortensamenstelling op basis van ordinaties (CCA). De kolommen met het relatieve belang voor bijen en zweefvliegen geeft de 'pseudo- $F^{\prime}$ als indicatie van de relatieve hoeveelheid variatie in de data die verklaard kan worden. Voor alle variabelen is het marginale effect sterk significant $\left(P_{(\text {adj })} \leq 0.005\right)$.

\begin{tabular}{lrr} 
Omgevingsfactor & Relatief belang: & Zweefvliegen \\
Landgebruik (hoofdtypen) & 21.6 & 25.5 \\
\hline Opp. natuur (hieronder opgesplitst in natuurtypen) & 18.1 & 15.8 \\
\hline Opp. bebouwd en infrastructuur & 10.3 & 16.7 \\
\hline Opp. landbouw & 6.6 & 10 \\
\hline Opp. water & 23.5 & 7.1 \\
\hline Natuurtype & 21.4 & 15.3 \\
\hline Opp. stuifzand en duin & 17.2 & 14.3 \\
\hline Opp. heide & 16.6 & 33.7 \\
\hline Opp. infrastructuur & 10.1 & 15.8 \\
\hline Opp. bos & 12.7 & 25.7 \\
\hline Opp. weiland & 9.6 & 14.9 \\
\hline Opp. onverharde wegen en fietspaden & 5.1 & 8.5 \\
\hline Opp. productiegrasland & 5 & 12.1 \\
\hline Opp. akkers & 3.1 & 12.5 \\
\hline Opp. natuurgrasland & & \\
\hline Opp. rietmoeras & & \\
\hline
\end{tabular}




\begin{tabular}{|c|c|c|}
\hline Omgevingsfactor & Relatief belang: & Zweefvliegen \\
\hline \multicolumn{3}{|l|}{ Fysisch-geografische regio's } \\
\hline FGR Hogere zandgronden (HZ) & 20.7 & 26.4 \\
\hline FGR Heuvelland (HL) & 12.5 & 4.3 \\
\hline FGR Rivierengebied ( $\mathrm{Ri})$ & 10.5 & 5.7 \\
\hline FGR Duinen, kalkarm (Du) & 9.9 & 5.2 \\
\hline FGR Laagveengebied (LV) & 1.8 & 14.7 \\
\hline \multicolumn{3}{|l|}{ Overige parameters } \\
\hline AHN-hoogte, Gemiddelde & 12.4 & 18.1 \\
\hline Grondwaterstand Gem (o.b.v. gem. van gvg en glg) & 8 & 15.6 \\
\hline Aantal fysisch-geografische series & 4.2 & 3.5 \\
\hline Aantal fysiotopen & 4 & 5.8 \\
\hline
\end{tabular}

Bij een vergelijking van de resultaten voor bijen en zweefvliegen (Tabel 1) valt het op dat voor zweefvliegen het relatieve belang van het oppervlak bos en de lengte aan sloten een stuk groter is voor het verklaren van de variatie in soortensamenstelling tussen kilometerhokken. Voor zweefvliegen is de aanwezigheid van bos of sloten vooral van belang voor soorten waarvan de larven afhankelijk zijn van de aanwezigheid van bomen (houtbewonende soorten) of water en moeras (aquatische en oevergebonden soorten). Omgekeerd is voor bijen het relatieve belang van het oppervlak open zand (stuifzand en duin) veel groter. Dit is vooral van belang voor soorten die ondergronds nestelen in droge, zonnige zandige bodem. Om dezelfde reden is waarschijnlijk ook heide relevant, want de heidevegetatie zelf onderhoudt maar een vrij bescheiden aantal bijensoorten. Verder is er bij bijen een duidelijk verschil in het relatieve belang van kalkarme en kalkrijke duinen, terwijl dit bij zweefvliegen nauwelijks het geval is. Voor de grondwaterstand is voor bijen vooral de variatie in grondwaterstand van belang, terwijl er voor zweefvliegen vooral een relatie is met de gemiddelde grondwaterstand.

\subsubsection{Kaart met landschapstypen}

Van de omgevingsfactoren met een relatief sterke relatie met de verspreidingspatronen van bijen en zweefvliegen wordt de grootste gemene deler gevormd door de fysisch-geografische ondergrond (fysisch-geografische regio's) en het type landgebruik (het relatieve aandeel natuur, landbouw en bebouwd gebied). De uiteindelijke indeling van kilometerhokken in clusters ('landschapstypen') is daarom gebaseerd op fysisch-geografische regio's met extra clusters voor kilometerhokken met een hoog aandeel bebouwd gebied ('urbaan') of een hoog aandeel landbouwkundig gebruik ('agrarisch gebied'). Dit levert een beperkt aantal duidelijk gedifferentieerde clusters op (zie Tabel 2). Bij de clusters die onderscheiden zijn op basis van de fysisch-geografische ondergrond gaat het om kilometerhokken die niet sterk worden gedomineerd door landbouwkundig gebruik en/of bebouwing (zie Tabel 2). Uit de ordinaties blijkt dat in kilometerhokken waar het landgebruik wél wordt gedomineerd door landbouw of bebouwing, de invloed van de fysisch-geografische ondergrond veel minder duidelijk is; deze wordt als het ware overschaduwd door het intensieve landgebruik. Via aanpassingen van inrichting en beheer van het landschap is het hier vaak mogelijk om populaties van meer kieskeurige soorten te herstellen. Binnen een bepaalde fysisch-geografische regio is het daarom mogelijk om verschillende ambitieniveaus te onderscheiden, mede op basis van het actuele of beoogde landgebruik (zie $\S 4.1 .2$ ). 
Tabel 2 Overzicht van de onderscheiden clusters (landschapstypen) in relatie tot de fysischgeografische ondergrond en het dominant landgebruik.

\begin{tabular}{|c|c|}
\hline Cluster (Landschapstype) & Toelichting (Fysisch-geografische eenheden of dominant landgebruik) \\
\hline \multicolumn{2}{|c|}{ Landbouw en/of bebouwing $<50 \%$} \\
\hline Duinen en rand getijdegebied & $\begin{array}{l}\text { Jonge kalkrijke duinen, jonge kalkarme duinen, oude duinen, Zoutwatergetijdegebied } \\
\text { (rand) }\end{array}$ \\
\hline Heuvelland & Plateaus en plateauranden, Hellingen, Dalen \\
\hline Hogere zandgronden & Glaciale gebieden, Stuifzandgebieden, Dekzandgebieden, Hoogvenen, Beekdalen \\
\hline Rivierengebied & Dynamische uiterwaarden, Overige uiterwaarden, Waarden en terrassen \\
\hline Zeekleigebied & Inpolderingen en droogmakerijen, Kreken en inlagen, Zoetwatergetijdegebied \\
\hline \multicolumn{2}{|c|}{ Landbouw en/of bebouwing dominant } \\
\hline Urbaan & Bebouwing beslaat $>50 \%$ van het $\mathrm{km}-\mathrm{hok}$ \\
\hline
\end{tabular}

Op basis van de expliciete koppeling met informatie over de fysisch-geografische ondergrond (Tabel 2) is een kaart vervaardigd met de potentiële ruimtelijke verspreiding van de clusters (Figuur 2). De landschapstypen op basis van fysisch-geografische regio's bepalen op hoofdlijnen de potentiële set aan soorten die in een gebied verwacht kan worden (vaak in natuurgebieden). Op een kleiner schaalniveau kunnen binnen deze fysisch-geografische regio's nog clusters onderscheiden worden voor urbaan gebied en agrarisch gebied. In principe is het mogelijk om de clusters nog verder onder te verdelen (vergelijkbaar met de hiërarchische indeling op basis van de fysisch-geografische ondergrond). Het nadeel hiervan is echter dat de indeling minder overzichtelijk wordt voor gebruikers en dat de betrouwbaarheid van de resultaten afneemt. Dit laatste hangt samen met het feit dat het aantal kilometerhokken voor sommige cluster dan te gering wordt (< ca. 20) voor een betrouwbare kwantificatie van de mate van associatie van de soorten met de clusters. Daarnaast ontstaan er bij een gedetailleerdere indeling meer problemen met de indeling van heterogene kilometerhokken. 


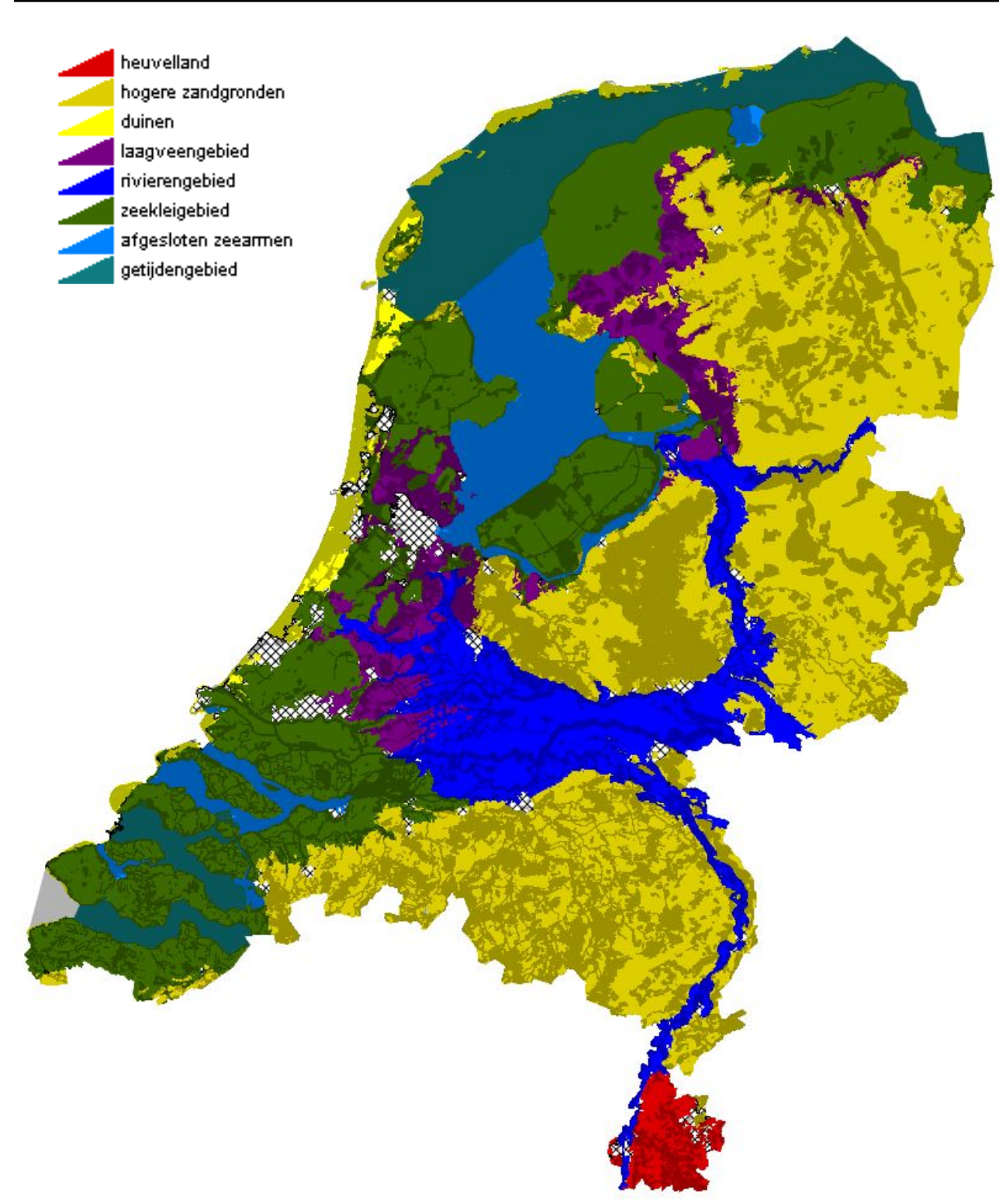

Figur 2 Kaart met de verspreiding van de onderscheiden landschapstypen (clusters). De landschapstypen op basis van fysisch-geografische regio's hebben elk een eigen kleur. Grote aquatische gebieden zijn wel aangegeven (getijdengebieden en afgesloten zeearmen), maar deze zijn voor dit project niet relevant. Op kleinere schaal worden binnen deze fysisch-geografische regio's twee landschapstypen onderscheiden op basis van het dominante landgebruik. De belangrijkste urbane gebieden worden weergegeven met een zwart-witarcering. Het landschapstype 'agrarisch gebied' komt verspreid in het hele land voor. Daarom is er binnen de fysisch-geografische regio's onderscheid gemaakt tussen gebieden met een relatief hoog aandeel natuur (donkere tint) en agrarisch gebied met een laag aandeel natuur (lichte tint).

\subsubsection{Bijen en zweefvliegen per landschapstype}

Tabel 3 geeft een matrix van de onderscheiden landschapstypen (clusters) met per landschapstype een overzicht van de kenmerkende bijensoorten. Per soort geeft deze matrix een overzicht van de landschapstypen waarin de soort vooral voorkomt op basis van de mate van binding met het cluster ('Phi coefficient of association', $\Phi \geq 0$ ). Met behulp van deze informatie kan de gebruiker snel inzoomen op relevante soorten bestuivers in een bepaalde beheersregio, om vervolgens gerichte maatregelen te kunnen nemen die aansluiten bij de eisen die deze soorten aan hun omgeving stellen.

Onder aan Tabel 3 wordt een overzicht gegeven van het aantal bijensoorten dat een relatieve voorkeur heeft voor een bepaald landschapstype. Hierbij zijn verschillende criteria gehanteerd voor de mate van binding aan het cluster, waarbij geldt hoe hoger de $\Phi$-waarde, hoe sterker de relatieve 
voorkeur. Bij een relatief lage drempelwaarde $(\Phi>0.05)$ heeft het heuvelland het hoogste aantal bijensoorten, gevolgd door het rivierengebied, de hogere zandgronden, het urbane gebied (de rijke subgroep) en de duinen. Indien gekeken wordt naar het aantal soorten met een hoge mate van binding aan het cluster ( $\Phi>0.25$ ), dan blijkt dat de duinen hoger scoren (een tweede plek na het heuvelland), terwijl de hogere zandgronden juist lager scoren. Ook voor de zweefvliegen (Tabel 4) herbergt het heuvelland het hoogste aantal soorten met een relatieve voorkeur voor dit cluster $(\Phi>0.05)$, gevolgd door de hogere zandgronden, de duinen, het laagveengebied en het rivierengebied. Wanneer hier de lat hoger gelegd wordt voor de mate van binding aan de clusters $(\Phi>0.15)$, dan stijgt het laagveengebied naar de tweede positie.

In gebieden die gedomineerd worden door intensieve landbouw is het aantal soorten zeer gering in vergelijking met de andere clusters (Tabel 3 en 4, linker kolom). Er zijn slechts enkele soorten waarvan het zwaartepunt van het voorkomen in het agrarisch gebied ligt, zoals Akkerhommel (Bombus pascuorum; zie Figuur 3), Snorzweefvlieg (Episyrphus balteatus; zie Figuur 4) en Blinde bij (Eristalis tenax). Diverse andere soorten hebben hun optimum in andere landschapstypen, maar komen nog wel relatief veel voor in het agrarisch gebied (Phi coefficient of association $>0$ ). Het gaat hierbij vaak om generalistische soorten, zoals Weidehommel (Bombus pratorum), Steenhommel (B. lapidarius), Aardhommel (B. terrestris), Rosse metselbij (Osmia bicornis) en Vosje (Andrena fulva). Bij de zweefvliegen gaat het om algemene soorten als Gewone driehoekzweefvlieg (Melanostoma mellinum), Witte halvemaanzweefvlieg (Scaeva pyrastri), Grote langlijf (Sphaerophoria scripta) en Menuetzweefvlieg (Syritta pipiens).

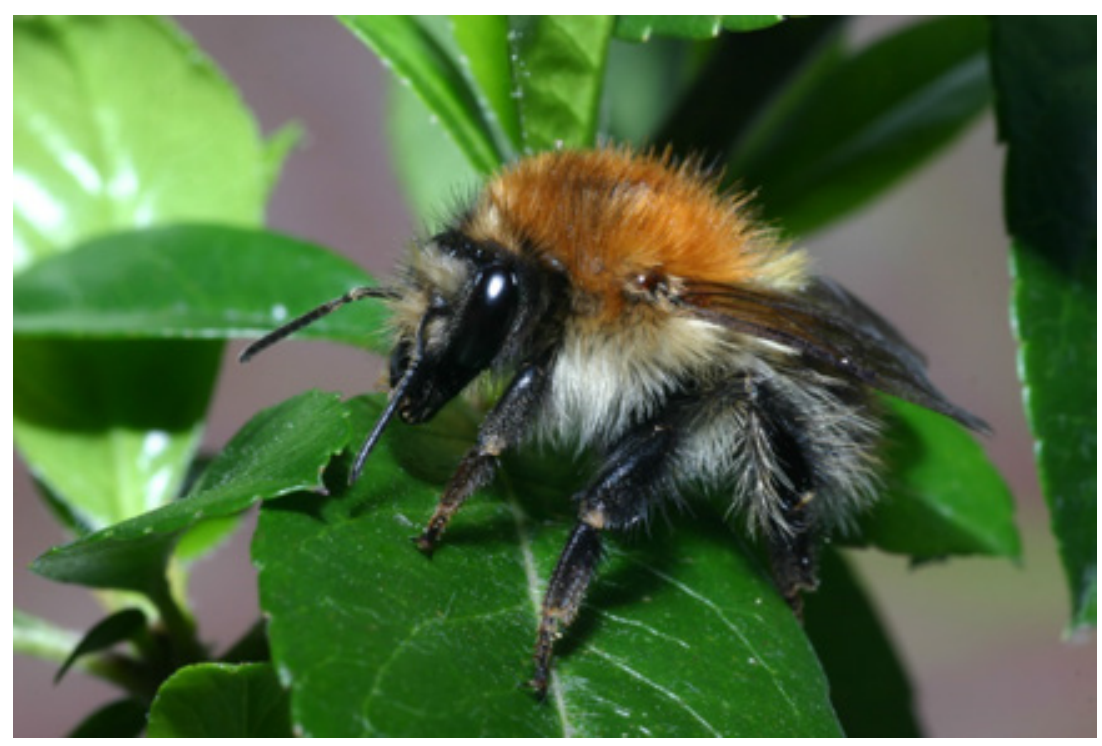

Figuur 3 De Akkerhommel (Bombus pascuorum) is een generalistische soort die in veel landschapstypen voorkomt. In veel landbouwgebieden is het de algemeenste hommel (foto: Tim Faasen). 


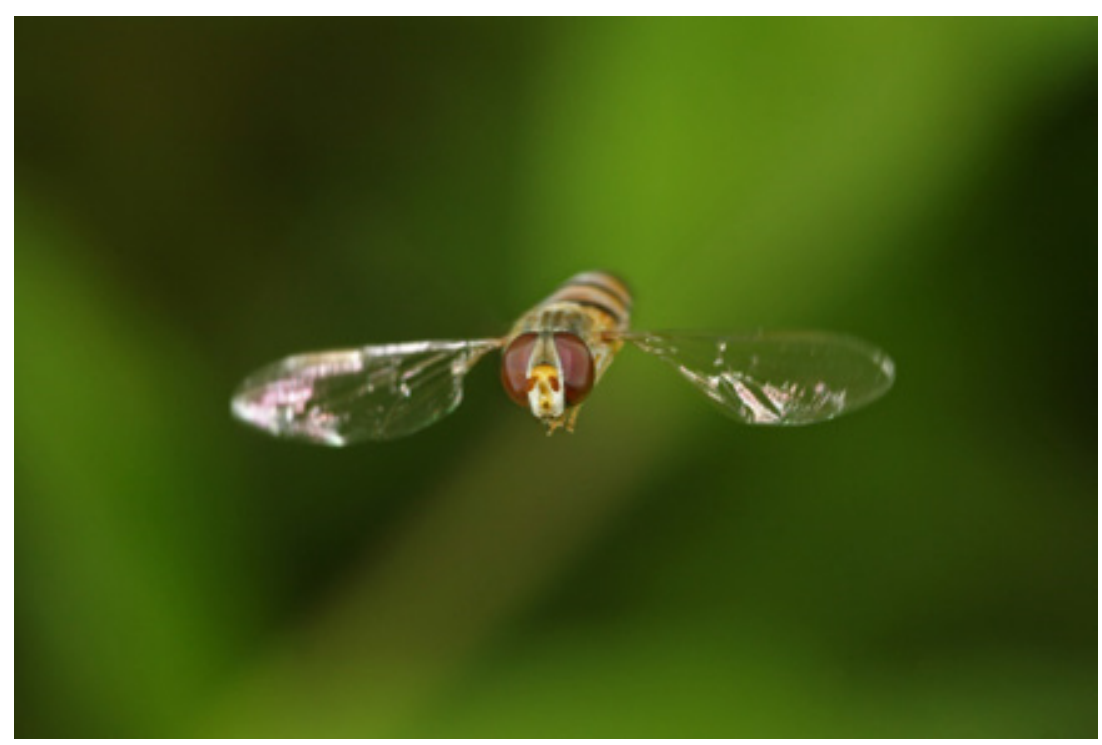

Figuur 4 De Snorzweefvlieg (Episyrphus balteatus) is een zeer algemene en weinig kieskeurige soort die ook veel voorkomt in het agrarisch gebied. De larven voeden zich met bladluizen en kunnen daardoor bijdragen aan de natuurlijke bestrijding van plagen (foto: Tim Faasen).

Binnen het urbane gebied is er bij bijen een differentiatie tussen soortenarme en soortenrijke gebieden. Rijkere gebieden worden waarschijnlijk vooral gekenmerkt door bloemrijke tuinen en parken in steden en dorpen en bloemrijke ruderale groenstroken op bedrijventerreinen (Koster, 2000; Peeters et al., 2012). Bijen die relatief veel in het urbane gebied voorkomen, zijn onder andere Tuinmaskerbij (Hylaeus hyalinatus), Grote bladsnijder (Megachile willughbiella) en Gewone franjegroefbij (Lasioglossum sexstrigatum). Ook bij de zweefvliegen zijn er diverse soorten met een relatieve voorkeur voor urbaan gebied, waaronder Stadsreus (Volucella zonaria; zie Figuur 5), Grote narcisvlieg (Merodon equestris), Tuingitje (Cheilosia caerulescens) en Vetplantgitje (Cheilosia semifasciata).

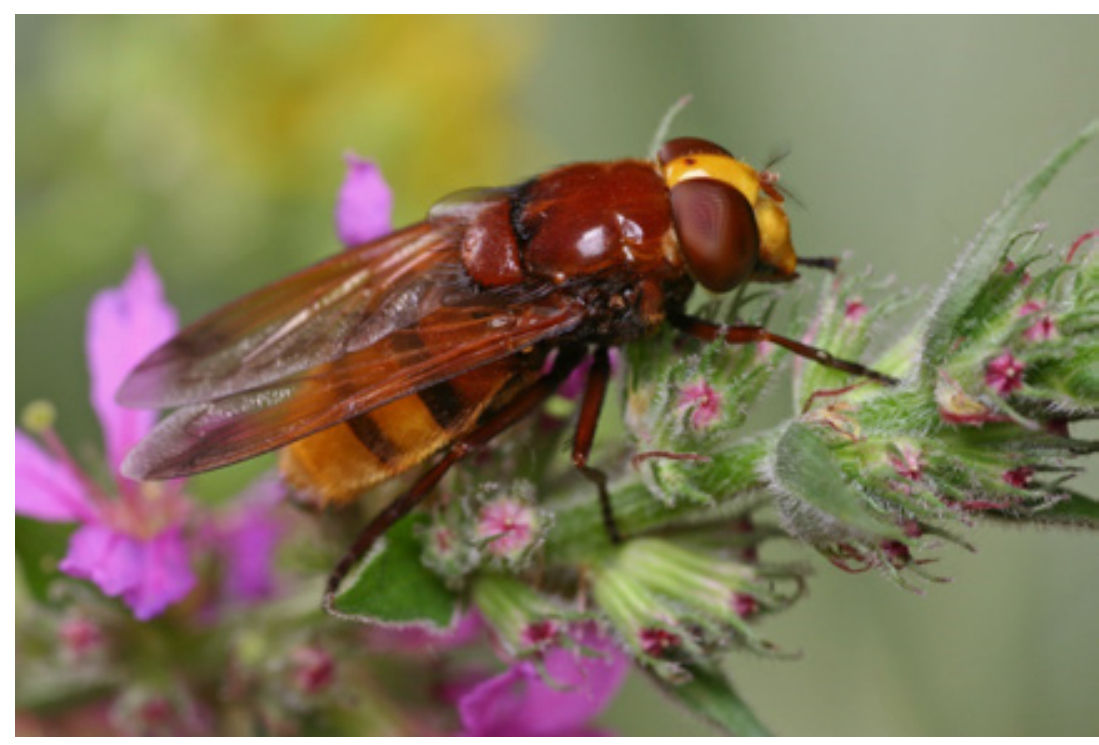

Figuur 5 De grootste Nederlandse zweefvlieg, de Stadsreus (Volucella zonaria), komt relatief vaak voor in tuinen en parken in stedelijk gebied (foto: Tim Faasen). 
Tabel 3 De relatieve voorkeur van bijensoorten voor verschillende landschapstypen op basis van de 'Phi coefficient of association' ( $\Phi$; hogere waarden met een dieper groene tint). Ten behoeve van de leesbaarheid zijn in de tabel alleen cellen met $\Phi \geq 0$ weergegeven. Soorten die opgenomen zijn op de Rode Lijst zijn rood en cursief weergegeven en dominante gewasbestuivers vet met een lichtblauwe achtergrond. Het aantal geselecteerde kilometerhokken waarin de soort is waargenomen, wordt in de laatste kolom vermeld. Voor bijen is binnen de clusters 'Agrarisch' en 'Urbaan' onderscheid gemaakt in een soortenarme en een soortenrijke subgroep (niet weergegeven op de kaart). In bijlage 1 is een alfabetisch gerangschikte naamlijst te vinden, inclusief Nederlandse namen.

\begin{tabular}{|c|c|c|c|c|c|c|c|c|c|c|c|}
\hline Soortnaam & $\begin{array}{l}\frac{E}{5} \\
\frac{5}{N} \\
\frac{5}{0} \\
\frac{n}{L} \\
\frac{0}{0} \\
\frac{0}{4}\end{array}$ & 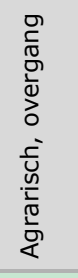 & 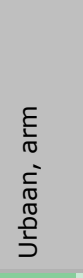 & 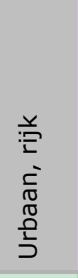 & 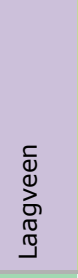 & 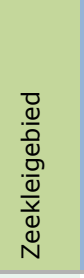 & 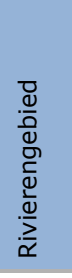 & 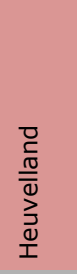 & 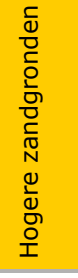 & 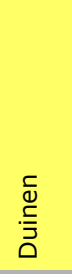 & 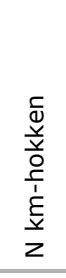 \\
\hline Bombus pascuorum & 0.34 & 0.17 & 0.38 & 0.17 & 0.29 & 0.07 & & & & & 1519 \\
\hline Bombus pratorum & 0.32 & 0.19 & 0.30 & 0.22 & 0.24 & 0.06 & & & & 0.01 & 959 \\
\hline Bombus lapidarius & 0.26 & 0.13 & 0.32 & 0.24 & 0.11 & 0.06 & 0.07 & & & & 1066 \\
\hline Bombus hypnorum & 0.23 & 0.16 & 0.37 & 0.21 & 0.23 & & & & & & 624 \\
\hline Bombus hortorum & 0.20 & 0.13 & 0.14 & 0.15 & 0.15 & 0.06 & 0.00 & 0.07 & & & 522 \\
\hline Anthidium manicatum & 0.17 & 0.14 & 0.35 & 0.31 & 0.03 & & & 0.07 & & & 267 \\
\hline Osmia bicornis & 0.16 & 0.25 & 0.32 & 0.42 & & & 0.00 & & & & 602 \\
\hline Bombus terrestris & 0.19 & 0.08 & & 0.05 & 0.08 & 0.19 & & & & 0.10 & 976 \\
\hline Bombus lucorum & 0.11 & 0.02 & & & 0.11 & 0.15 & & & 0.01 & 0.14 & 523 \\
\hline Anthophora plumipes & 0.07 & 0.16 & 0.18 & 0.26 & & 0.02 & 0.06 & 0.20 & & & 262 \\
\hline Bombus campestris & 0.04 & 0.06 & & 0.01 & 0.04 & 0.10 & 0.01 & 0.02 & & & 285 \\
\hline Stelis punctulatissima & 0.03 & 0.12 & & 0.17 & & 0.00 & 0.00 & 0.05 & & & 81 \\
\hline Chelostoma rapunculi & 0.00 & 0.14 & 0.04 & 0.25 & & & & 0.28 & & & 153 \\
\hline Andrena fulva & 0.00 & 0.20 & 0.17 & 0.33 & 0.09 & & 0.10 & & & & 499 \\
\hline Andrena flavipes & & 0.26 & & 0.12 & & 0.14 & 0.30 & 0.23 & & & 667 \\
\hline Andrena haemorrhoa & & 0.25 & & 0.23 & & 0.11 & 0.21 & & 0.11 & & 892 \\
\hline Andrena nitida & & 0.16 & & 0.17 & & 0.15 & 0.26 & 0.15 & & & 402 \\
\hline Hylaeus hyalinatus & & 0.15 & & 0.25 & & & 0.10 & 0.04 & & & 187 \\
\hline Lasioglossum morio & & 0.15 & & 0.17 & & & 0.13 & 0.32 & & & 322 \\
\hline Andrena bicolor & & 0.14 & & 0.21 & 0.07 & & 0.07 & 0.28 & & & 278 \\
\hline Megachile willughbiella & & 0.13 & & 0.30 & 0.10 & & & 0.02 & & 0.06 & 366 \\
\hline Andrena tibialis & & 0.13 & & 0.27 & 0.05 & 0.05 & 0.04 & & & & 158 \\
\hline Megachile centuncularis & & 0.12 & & 0.22 & 0.03 & 0.04 & & 0.03 & & 0.03 & 262 \\
\hline Andrena carantonica & & 0.12 & & 0.17 & & 0.07 & 0.18 & 0.04 & & & 375 \\
\hline Osmia caerulescens & & 0.12 & & 0.17 & & 0.01 & & 0.07 & & & 87 \\
\hline Lasioglossum calceatum & & 0.11 & & 0.07 & & 0.07 & 0.04 & 0.22 & & 0.18 & 682 \\
\hline Andrena chrysosceles & & 0.11 & & 0.19 & & 0.11 & 0.29 & 0.33 & & & 326 \\
\hline Chalicodoma ericetorum & & 0.11 & & 0.15 & & & 0.11 & 0.16 & & & 121 \\
\hline Heriades truncorum & & 0.10 & & 0.21 & & & 0.08 & 0.05 & 0.15 & & 282 \\
\hline Lasioglossum sexstrigatum & & 0.10 & & 0.28 & & 0.06 & & & 0.10 & 0.00 & 354 \\
\hline Melitta haemorrhoidalis & & 0.09 & & 0.22 & & & & 0.14 & 0.02 & & 95 \\
\hline Halictus tumulorum & & 0.08 & & 0.00 & & 0.07 & 0.14 & 0.30 & & & 418 \\
\hline Osmia cornuta & & 0.08 & 0.03 & 0.21 & & & 0.04 & 0.08 & & & 119 \\
\hline Anthophora furcata & & 0.08 & & 0.16 & & & & 0.19 & & 0.03 & 73 \\
\hline Andrena subopaca & & 0.07 & & 0.09 & & 0.12 & 0.11 & 0.15 & 0.02 & & 330 \\
\hline Melecta albifrons & & 0.07 & & 0.11 & & & 0.07 & 0.19 & & & 55 \\
\hline Colletes daviesanus & & 0.06 & & 0.18 & & & 0.10 & 0.02 & 0.07 & & 221 \\
\hline Hylaeus communis & & 0.06 & & 0.17 & & & 0.02 & 0.10 & 0.10 & 0.02 & 386 \\
\hline Colletes hederae & 0.04 & 0.05 & & 0.01 & & & & 0.18 & & 0.03 & 16 \\
\hline Melitta nigricans & & 0.04 & & 0.06 & & & 0.28 & 0.02 & 0.02 & & 115 \\
\hline Lasioglossum minutissimum & & 0.04 & & 0.08 & 0.01 & & 0.13 & 0.12 & & & 105 \\
\hline Osmia niveata & & 0.03 & & 0.04 & & & 0.12 & 0.17 & & & 36 \\
\hline Andrena minutula & & 0.03 & & 0.11 & 0.00 & & 0.26 & 0.24 & & & 201 \\
\hline Nomada marshamella & & 0.03 & & & & 0.09 & 0.21 & 0.22 & & & 197 \\
\hline Melitta leporina & & 0.03 & & & & 0.04 & 0.02 & 0.23 & & & 77 \\
\hline Andrena praecox & & 0.05 & & 0.08 & & 0.12 & 0.15 & & 0.11 & & 248 \\
\hline Bombus sylvestris & & 0.08 & & 0.03 & 0.21 & 0.06 & & 0.02 & 0.01 & 0.00 & 229 \\
\hline Hylaeus pectoralis & & & & 0.02 & 0.07 & 0.06 & & & & 0.03 & 25 \\
\hline
\end{tabular}


Soortnaam

Epeoloides coecutiens

Bombus bohemicus

Bombus ruderarius

Bombus veteranus

Andrena rosae

Andrena mitis

Nomada fulvicornis

Andrena bimaculata

Andrena synadelpha

Andrena pilipes

Coelioxys elongata

Nomada ferruginata

Nomada ruficornis

\section{Lasioglossum malachurum}

\section{Andrena labialis}

Hylaeus cornutus

Melitta tricincta

Andrena semilaevis

Nomada stigma

Nomada sexfasciata

Andrena wilkella

Sphecodes miniatus

Sphecodes marginatus

Nomada alboguttata

Lasioglossum quadrinotatum

Lasioglossum quadrinotatulum

\section{Lasioglossum pauxillum}

Andrena florea

Andrena hattorfiana

Nomada fucata

Halictus scabiosae

Sphecodes ephippius

\section{Andrena dorsata}

Andrena gravida

Nomada flavoguttata

Andrena ovatula

Nomada zonata

Hoplitis leucomelana

Andrena labiata

Nomada bifasciata

Hylaeus signatus

Andrena lathyri

Bombus vestalis

Bombus rupestris

Lasioglossum parvulum

Sphecodes rubicundus

Andrena humilis

Sphecodes monilicornis

Eucera nigrescens

Nomada armata

Nomada conjungens

Nomada striata

Andrena strohmella

Hylaeus gredleri

Colletes similis

Lasioglossum xanthopus

Halictus maculatus

Nomada integra
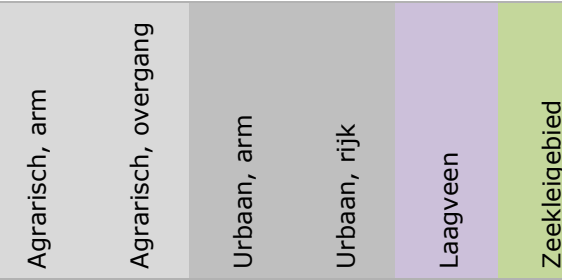

0.16

0.05

0.01

0.01

0.0

0.05

0.15

0.06

0.12

0.08

0.10

0.14

0.02

0.05

0.09

0.10

0.06

0.01

$+2$

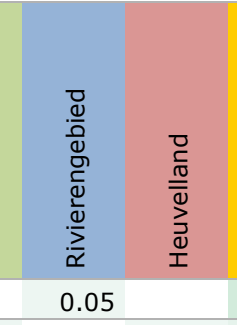

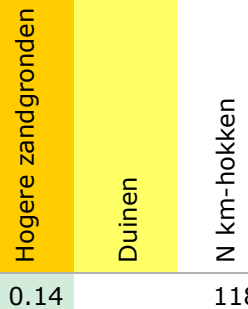

$\begin{array}{llll}0.05 & 0.07 & 0.10 & 115\end{array}$

$0.13 \quad 129$

$\begin{array}{lll}0.11 & 0.07 & 35\end{array}$

73

$0.16 \quad 79$

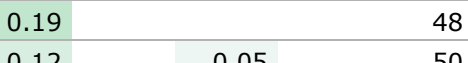

$\begin{array}{lll}0.12 & 0.05 & 50\end{array}$

$\begin{array}{lll}0.08 & & 18 \\ 0.05 & 0.03 \quad 10\end{array}$

\begin{tabular}{|l|l|l|l|}
0.10 & 0.28 & 137 \\
\hline
\end{tabular}

\begin{tabular}{llllll}
0.08 & 0.26 & 0.23 & 0.07 & 355 \\
\hline
\end{tabular}

$\begin{array}{ll}0.26 & 0.25 \\ 0.23 & 0.15\end{array}$

\begin{tabular}{lll}
0.23 & 0.15 & 65 \\
\hline
\end{tabular}

$\begin{array}{lll}0.22 & 0.07 & 32\end{array}$

$\begin{array}{lll}0.21 & 0.13 & 32\end{array}$

$\begin{array}{lll}0.18 & 0.11 & 34\end{array}$

$\begin{array}{lll}0.14 & 0.11 & 18\end{array}$

$\begin{array}{llr}0.07 & 0.06 & 6\end{array}$

$\begin{array}{llll}0.17 & 0.15 & 0.03 & 102\end{array}$

$\begin{array}{llll}0.09 & 0.09 & 0.03 & 183\end{array}$

\begin{tabular}{|l|l|l|r|}
0.15 & 0.01 & 0.06 & 69 \\
\hline
\end{tabular}

$\begin{array}{lll}0.18 & 0.17 & 249\end{array}$

0.13

0.20

0.21

0.02

0.07

0.28

0.07

0.14

0.27

0.18

0.24

0.08

0.19

0.04

0.13

0.16

0.16

0.05

0.07

0.09

0.04

0.10

0.07

0.15

0.06

0.05

0.17

0.05

0.06

0.10

0.04

$0.10 \quad 70$

0.50

0.42

0.40
0.35

\begin{tabular}{rr}
0.35 \\
0.34 \\
\hline
\end{tabular}

\begin{tabular}{|l|l|l|}
\hline 0.33 & 0.06 & 183 \\
\hline
\end{tabular}

\begin{tabular}{ll|l}
0.32 & 0.01 & 307
\end{tabular}

$0.31 \quad 97$

\begin{tabular}{l}
$0.30 \quad 252$ \\
\hline
\end{tabular}

\begin{tabular}{l|l|l|}
0.30 & 0.06 & 104 \\
\hline
\end{tabular}

0.25

0.25

0.23

0.23

0.22

0.22

0.21

0.21

0.21

0.21

0.21

0.20

0.20

0.19

0.19

0.18

0.17

0.16

$\begin{array}{ll}0.16 & 0.16\end{array}$

0.00

0.03

0.12

0.16

0.14

0.13

0.00

0.04

91

$0.00 \quad 302$

302

16

0.05

40
16


Soortnaam
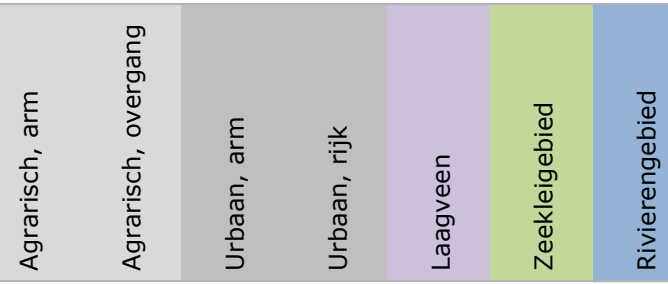

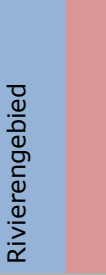

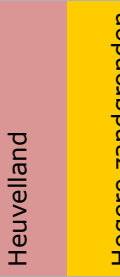

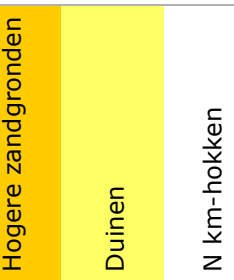

Andrena viridescens

0.06

0.11

Anthidium punctatum

0.28

Nomada lathburiana

0.03

Sphecodes gibbus

Andrena angustior

\section{Andrena cineraria}

Nomada flava

0.00

0.33

0.04

0.29

0.04

Ceratina cyanea

0.01

$\begin{array}{ll}0.09 & 0.07\end{array}$

Lasioglossum pallens

Andrena minutuloides

Lasioglossum laticeps

Chelostoma campanularum

0.01

Sphecodes ferruginatus

Andrena fulvago

0.05

0.15

0.32

0.37

0.36

0.36

0.35

0.34

0.31

Sphecodes majalis

0.01

Lasioglossum lativentre

Anthophora retusa

Lasioglossum pygmaeum

Sphecodes niger

Bombus soroeensis

Sphecodes hyalinatus

Hoplitis adunca

0.00

0.03

Andrena pandellei

Megachile pilidens

Hylaeus difformis

Hylaeus styriacus

Eucera longicornis

Anthophora quadrimaculata

0.02

Andrena agilissima

Andrena polita

0.07

0.00

Nomada distinguenda

Coelioxys aurolimbata

Lasioglossum nitidulum

0.00

Osmia leaiana

0.02

0.03

Lasioglossum nitidiusculum

Macropis fulvipes

Lasioglossum villosulum

Halictus rubicundus

Lasioglossum fulvicorne

Nomada sheppardana

Sphecodes puncticeps

Osmia aurulenta

Hylaeus brevicornis

0.01

0.08

0.01

0.15

Andrena fuscipes

Nomada rufipes

Lasioglossum sabulosum

Nomada fuscicornis

Andrena fulvida

Andrena nigriceps

Lasioglossum fratellum

Nomada similis

Nomada obscura

Hylaeus rinki

Andrena falsifica

Andrena tarsata

Stelis signata

Panurgus banksianus

Nomada leucophthalma

0.01

0.02

0.02

0.01

0.01

0.02

$0.25 \quad 292$

0.08

$0.12 \quad 77$

238

0.05

399

$0.11 \quad 20$

$0.10 \quad 21$

$0.09 \quad 13$


Soortnaam
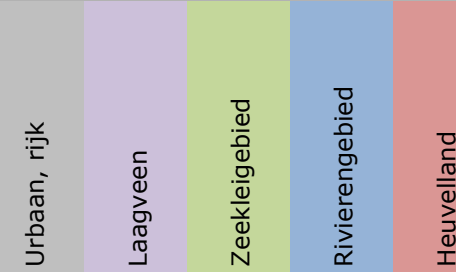

Bombus magnus

0.02

Bombus cryptarum

0.06

Sphecodes scabricollis

0.00

0.16

Andrena vaga

0.2

0.07

Panurgus calcaratus

$\begin{array}{llll}0.00 & 0.07 & 0.30\end{array}$

Anthidiellum strigatum

0.02

$0.14 \quad 0.22$

\begin{tabular}{lll}
0.01 & 0.18 \\
\hline
\end{tabular}

Andrena ruficrus

Andrena lapponica

Andrena denticulata

0.10

0.03

Andrena fucata

Sphecodes pellucidus

0.00

0.16

Epeolus cruciger

0.09

0.17

0.21

0.29

0.27

Colletes succinctus

Sphecodes reticulatus 0.00

0.14

Osmia uncinata

Lasioglossum prasinum

Bombus humilis

0.00

\begin{tabular}{llll}
0.12 & 0.04 & 29 \\
\hline
\end{tabular}

Megachile leachella

Coelioxys mandibularis

Megachile maritima

Colletes marginatus

Andrena argentata

$\begin{array}{lll}0.08 & 0.03 & 18\end{array}$

Epeolus tarsalis

Hoplitis claviventris

$\begin{array}{lll}0.05 & 0.03 & 6\end{array}$

$0.47 \quad 121$

Lasioglossum tarsatum

\begin{tabular}{|c|c|c|c|c|c|c|c|c|c|c|c|}
\hline & & & & & & & & & & & \\
\hline Hylaeus incongruus & & 0.00 & & 0.06 & & & & & & 0.13 & 83 \\
\hline Colletes impunctatus & & & & 0.01 & & & & & & 0.12 & 10 \\
\hline Coelioxys conoidea & & & & & & & 0.01 & & & 0.11 & 9 \\
\hline Megachile dorsalis & & & & & & & & & & 0.10 & 5 \\
\hline Bombus muscorum & & & & & 0.12 & 0.11 & & & & 0.18 & 78 \\
\hline Colletes halophilus & & & & & & 0.04 & & & & 0.29 & 61 \\
\hline Megachile circumcincta & & & & & & 0.01 & & 0.00 & & 0.24 & 58 \\
\hline Andrena apicata & & & & & & 0.02 & & & 0.06 & 0.08 & 31 \\
\hline Epeolus variegatus & & & & & & & 0.17 & & 0.05 & 0.18 & 173 \\
\hline Lasioglossum leucozonium & & & & & & & & 0.14 & 0.10 & 0.25 & 456 \\
\hline Lasioglossum punctatissimum & & & & & & & & 0.18 & 0.06 & 0.22 & 149 \\
\hline Lasioglossum albipes & & & & & & & & 0.09 & 0.05 & 0.18 & 153 \\
\hline Osmia spinulosa & & & & & & & & 0.02 & & 0.17 & 19 \\
\hline Dasypoda hirtipes & & & & & & & & & 0.25 & 0.33 & 572 \\
\hline Andrena barbilabris & & & & 0.13 & & & & & 0.09 & 0.30 & 405 \\
\hline Halictus confusus & & & & & & & & & 0.09 & 0.28 & 184 \\
\hline Lasioglossum brevicorne & & & & 0.02 & & & & & 0.08 & 0.08 & 32 \\
\hline Stelis breviuscula & & 0.02 & 0.00 & 0.10 & 0.06 & & & & 0.07 & & 43 \\
\hline Xylocopa violacea & 0.05 & 0.01 & 0.10 & 0.06 & & 0.02 & 0.01 & & & & 11 \\
\hline Bombus norvegicus & & & & 0.07 & & & & 0.02 & 0.05 & 0.03 & 30 \\
\hline Lasioglossum leucopus & & & & 0.03 & 0.09 & & 0.06 & & 0.06 & 0.04 & 178 \\
\hline Nomada fabriciana & & & & 0.02 & 0.00 & 0.05 & 0.27 & 0.26 & & & 231 \\
\hline Nomada goodeniana & & & & 0.00 & & 0.02 & 0.25 & 0.13 & 0.02 & & 205 \\
\hline Andrena ventralis & & 0.01 & & 0.07 & 0.02 & 0.06 & 0.22 & 0.05 & & & 232 \\
\hline Lasioglossum sexnotatum & & 0.01 & & 0.12 & & & 0.13 & 0.02 & 0.07 & 0.09 & 168 \\
\hline Lasioglossum semilucens & & 0.00 & & 0.01 & & & 0.08 & 0.08 & 0.02 & & 87 \\
\hline Andrena proxima & & 0.01 & & 0.02 & & & 0.20 & 0.30 & & & 134 \\
\hline Sphecodes crassus & & & & 0.01 & & & 0.12 & 0.28 & 0.02 & & 133 \\
\hline Hylaeus dilatatus & & & & 0.01 & & & 0.16 & 0.21 & 0.04 & & 94 \\
\hline Nomada signata & & & & 0.09 & & & 0.02 & 0.20 & 0.06 & & 146 \\
\hline Chelostoma florisomne & & 0.00 & & 0.02 & & & 0.17 & 0.20 & 0.06 & & 117 \\
\hline Nomada flavopicta & & 0.02 & & & & 0.02 & 0.12 & 0.20 & & & 91 \\
\hline
\end{tabular}


Soortnaam

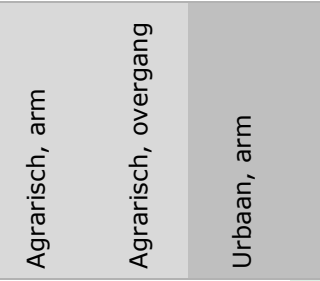

Nomada panzeri
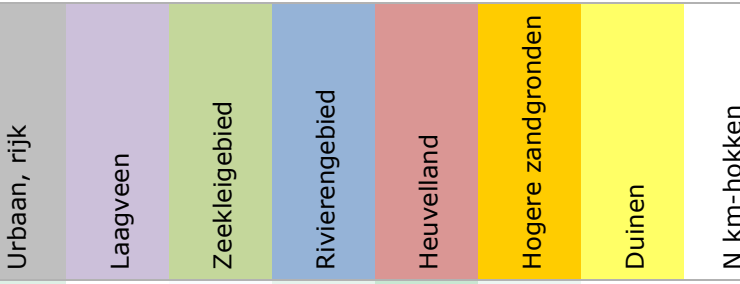

Nomada femoralis

0.10

0.01

0.07

0.17

0.05

Stelis ornatula

0.01

Sphecodes longulus

0.01

0.03

0.00

$0.16 \quad 0.01$

0.15

Megachile ligniseca

0.00

0.03

Andrena helvola

0.02

0.003

0.09

Hylaeus confusus

0.01

$0.05 \quad 0.03$

0.03

0.15

Sphecodes geoffrellus

Hylaeus pictipes

$0.04 \quad 0.05$

0.14

Andrena clarkella

0.00

$0.10 \quad 0.03$

0.03

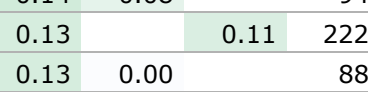

0.08

17

Nomada succincta

0.01

0.05

0.11

Macropis europaea

0.02

$0.06 \quad 0.14$

0.05

$0.07 \quad 0.10$

Lasioglossum zonulum

Andrena nigroaenea

Lasioglossum lucidulum

Andrena varians

0.02

0.02

Megachile lapponica

0.06

0.00

0.07

Colletes cunicularius

$\begin{array}{ll}0.07 & 0.00 \\ 0.04\end{array}$

Sphecodes albilabris

Colletes fodiens

Bombus jonellus

Megachile versicolor

Coelioxys inermis

Hylaeus punctulatissimus

Andrena niveata

Hoplitis tridentata

Nomada guttulata

Stelis phaeoptera

Stelis minuta

Coelioxys alata

Lasioglossum rufitarse

Hylaeus clypearis

Aantal soorten met $\Phi>0.0$

Aantal soorten met $\Phi>0.05$

Aantal soorten met $\Phi>0.15$

Aantal soorten met $\Phi>0.25$

0.02

$0.00+0$

\begin{tabular}{|l|r|r|r|r|}
0.09 & 0.12 & 0.05 & 0.37 & 357 \\
\hline
\end{tabular}

\begin{tabular}{|l|l|l|l|l|}
0.12 & 0.01 & 0.09 & 0.33 & 331 \\
\hline
\end{tabular}

\begin{tabular}{|l|l|l|l|}
0.12 & 0.02 & 0.28 & 184 \\
\hline
\end{tabular}

0.00

$0.00 \quad 0.01$

\begin{tabular}{l|lll|}
\hline .01 & 0.16 & 0.17 & 188 \\
\hline
\end{tabular}

$0.02 \quad 0.05$

$0.13 \quad 0.02$

$0.14 \quad 137$

0.02

0.11

0.03

0.1366

$0.02 \quad 0.05$

0.02

0.06

0.10

$0.08 \quad 0.06$

5

$\begin{array}{ll}0.03 & 0.08\end{array}$

0.06

$\begin{array}{lll}0.01 & 0.01 & 0.07\end{array}$

0.02

0.07

0.01

0.06

$0.06 \quad 0.00 \quad 0.04 \quad 606$

\begin{tabular}{rrrrrrrrrr} 
& & & & & 0.06 & & 0.00 & 0.04 & 6 \\
\hline 0.01 & & 0.05 & & & & & 0.06 & & 9 \\
\hline 0.01 & & 0.06 & & & 0.04 & & 0.01 & & 5 \\
\hline 82 & 14 & 121 & 29 & 58 & 146 & 167 & 112 & 72 &
\end{tabular}

$\begin{array}{rrrrrrrrrr}16 & 82 & 14 & 121 & 29 & 58 & 146 & 167 & 112 & 72 \\ 10 & 43 & 10 & 68 & 18 & 32 & 104 & 146 & 80 & 51 \\ 8 & 10 & 8 & 30 & 5 & 2 & 40 & 100 & 26 & 28 \\ 3 & 3 & 6 & 9 & 1 & 0 & 12 & 39 & 6 & 13\end{array}$


Tabel 4 De relatieve voorkeur van zweefvliegen voor verschillende landschapstypen op basis van de 'Phi coefficient of association' ( $\Phi$; hogere waarden met een dieper groene tint). Ten behoeve van de leesbaarheid zijn in de tabel alleen cellen met $\Phi \geq 0$ weergegeven. Soorten die opgenomen zijn op de Rode Lijst zijn rood en cursief weergegeven en dominante gewasbestuivers vet met een lichtblauwe achtergrond. Het aantal geselecteerde kilometerhokken waarin de soort is waargenomen, wordt in de laatste kolom vermeld. In bijlage 1 is een alfabetisch gerangschikte naamlijst te vinden, inclusief Nederlandse namen.

\begin{tabular}{|c|c|c|c|c|c|c|c|c|c|}
\hline Soortnaam & $\begin{array}{l}\frac{5}{0} \\
\frac{0}{2} \\
\frac{0}{0} \\
\frac{0}{4} \\
\end{array}$ & 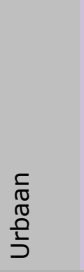 & 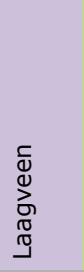 & 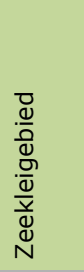 & 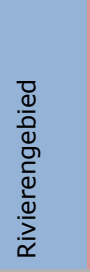 & 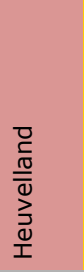 & 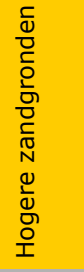 & $\begin{array}{l}\stackrel{\complement}{d} \\
\stackrel{\frac{5}{3}}{0}\end{array}$ & 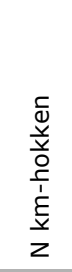 \\
\hline Episyrphus balteatus & 0.24 & 0.10 & & 0.07 & & 0.16 & & 0.06 & 2325 \\
\hline Eristalis tenax & 0.24 & 0.15 & & 0.08 & 0.01 & 0.08 & & 0.11 & 2324 \\
\hline Heringia vitripennis & 0.19 & 0.00 & & & 0.04 & 0.10 & & & 43 \\
\hline Melanostoma mellinum & 0.15 & 0.00 & 0.03 & 0.07 & 0.07 & 0.15 & & 0.01 & 1282 \\
\hline Scaeva pyrastri & 0.10 & 0.08 & & 0.01 & & 0.09 & & 0.14 & 792 \\
\hline Eristalis anthophorina & 0.02 & & 0.08 & & & & 0.00 & & 8 \\
\hline Eupeodes corollae & 0.00 & 0.08 & & 0.07 & 0.00 & 0.05 & & 0.11 & 1026 \\
\hline Platycheirus clypeatus & 0.00 & & 0.14 & & 0.02 & 0.09 & 0.07 & 0.02 & 505 \\
\hline Eristalis arbustorum & 0.05 & 0.00 & & 0.15 & 0.07 & 0.14 & & & 1180 \\
\hline Eristalinus sepulchralis & 0.02 & 0.00 & 0.16 & 0.25 & 0.06 & & & 0.03 & 885 \\
\hline Helophilus pendulus & 0.00 & 0.03 & 0.11 & 0.19 & 0.02 & & 0.05 & 0.02 & 2187 \\
\hline Helophilus trivittatus & 0.00 & 0.00 & 0.09 & 0.14 & 0.03 & & 0.01 & 0.15 & 1646 \\
\hline Sphaerophoria scripta & 0.05 & 0.00 & & 0.08 & 0.00 & 0.14 & 0.01 & 0.10 & 1556 \\
\hline Meligramma guttata & 0.04 & 0.04 & & & 0.02 & 0.07 & & & 37 \\
\hline Syritta pipiens & 0.03 & 0.00 & & 0.06 & 0.00 & 0.16 & 0.01 & 0.03 & 1420 \\
\hline Cheilosia vernalis & 0.00 & 0.00 & & 0.00 & 0.01 & 0.23 & & & 120 \\
\hline Rhingia campestris & 0.00 & 0.00 & 0.12 & 0.01 & 0.19 & 0.23 & & & 1174 \\
\hline Eupeodes luniger & 0.00 & 0.11 & & & 0.03 & 0.18 & & 0.04 & 520 \\
\hline Eumerus strigatus & 0.00 & & & 0.05 & 0.00 & 0.13 & & & 76 \\
\hline Neoascia podagrica & 0.00 & 0.04 & 0.05 & 0.05 & 0.05 & 0.09 & & & 390 \\
\hline Chrysotoxum cautum & 0.00 & & & & 0.09 & 0.07 & 0.20 & & 412 \\
\hline Scaeva selenitica & 0.00 & 0.08 & & & & 0.07 & 0.09 & 0.10 & 536 \\
\hline Eupeodes latifasciatus & 0.00 & 0.00 & & & 0.04 & 0.08 & & 0.07 & 262 \\
\hline Sphaerophoria rueppelli & 0.00 & 0.05 & & 0.03 & 0.03 & & & 0.08 & 89 \\
\hline Volucella zonaria & & 0.33 & & 0.04 & 0.07 & 0.05 & & & 750 \\
\hline Merodon equestris & & 0.22 & & & & & & 0.03 & 556 \\
\hline Cheilosia caerulescens & & 0.14 & & & & 0.03 & & & 57 \\
\hline Epistrophe eligans & & 0.12 & & 0.00 & & 0.14 & 0.02 & 0.04 & 599 \\
\hline Cheilosia semifasciata & & 0.11 & & & 0.01 & 0.02 & 0.01 & 0.00 & 93 \\
\hline Eumerus funeralis & & 0.11 & & 0.00 & & & & 0.06 & 92 \\
\hline Didea fasciata & & 0.07 & & & & 0.02 & 0.09 & 0.06 & 185 \\
\hline Meliscaeva auricollis & & 0.09 & & & & 0.10 & & 0.15 & 396 \\
\hline Anasimyia lineata & & 0.00 & 0.34 & 0.01 & 0.04 & & & & 336 \\
\hline Neoascia tenur & & & 0.28 & 0.04 & 0.03 & & & & 196 \\
\hline Platycheirus fulviventris & & & 0.25 & 0.00 & & & & 0.03 & 99 \\
\hline Lejogaster tarsata & & & 0.24 & & & & & & 64 \\
\hline Orthonevra intermedia & & & 0.22 & & & & & & 31 \\
\hline Helophilus hybridus & & 0.00 & 0.21 & 0.05 & & & & & 420 \\
\hline Parhelophilus consimilis & & & 0.20 & & & & & & 14 \\
\hline Neoascia meticulosa & & & 0.18 & 0.04 & 0.05 & & & & 90 \\
\hline Platycheirus scambus & & & 0.16 & 0.05 & & & & & 86 \\
\hline Platycheirus occultus & & & 0.15 & & & & & 0.05 & 50 \\
\hline Orthonevra geniculata & & & 0.13 & & & & & & 12 \\
\hline Sericomyia lappona & & & 0.10 & & & & & & 8 \\
\hline Anasimyia contracta & & 0.01 & 0.07 & 0.01 & 0.01 & & & 0.01 & 28 \\
\hline Eristalis horticola & & 0.00 & 0.29 & 0.09 & 0.01 & 0.00 & & & 1130 \\
\hline Tropidia scita & & 0.00 & 0.29 & 0.25 & 0.03 & & & & 584 \\
\hline Eristalis intricaria & & 0.02 & 0.25 & 0.10 & 0.03 & & 0.01 & 0.07 & 1259 \\
\hline Eristalis abusiva & & & 0.20 & 0.12 & 0.04 & & & 0.05 & 283 \\
\hline
\end{tabular}


Soortnaam
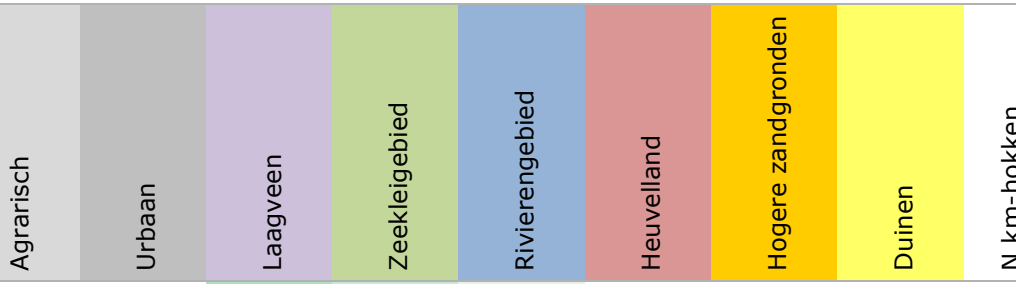

Lejogaster metallina

0.17

0.11

0.05

Anasimyia interpuncta

0.08

0.02

194

Melanogaster hirtella

0.00

0.17

0.06

0.14

Pyrophaena granditarsa

0.14

0.09

0.11

Parhelophilus frutetorum

0.09

0.03

0.06

Eristalis picea

Sericomyia silentis

0.12

Anasimyia transfuga

0.16

Cheilosia albitarsis / ranunculi

0.01

0.06

0.07

0.07

0.07

Sphaerophoria interrupta

Cheilosia carbonaria

Neoascia geniculata

$0.02 \quad 0.02$

0.13

0.13
0.05

Cheilosia velutina

0.02

0.05

Cheilosia grossa

Triglyphus primus

Cheilosia illustrata

0.01

0.00

0.00

0.00

0.00

0.05

Pipizella viduata

Platycheirus albimanus

Cheilosia proxima

Chrysogaster solstitialis

Criorhina ranunculi

Pipizella annulata

Cheilosia variabilis

Cheilosia canicularis / himantopus

Xanthogramma citrofasciatum

Chrysotoxum bicinctum

Baccha elongata

0.02

Criorhina asilica

Criorhina floccosa

Cheilosia lenis

Microdon devius

Chrysogaster cemiteriorum

Criorhina berberina

Sphegina clunipes

Brachyopa scutellaris

Cheilosia barbata

Eumerus tricolor

Olbiosyrphus laetus

Pipiza bimaculata

Leucozona lucorum of inopinata

Criorhina pachymera

Meliscaeva cinctella

Portevinia maculata

Pipiza austriaca

Eumerus ornatus

Orthonevra nobilis

Xylota xanthocnema

Sphegina elegans

Brachypalpoides lentus

Cheilosia fasciata

Dasysyrphus hilaris

Sphaerophoria taeniata

Heringia pubescens

Caliprobola speciosa

Sphegina verecunda

Brachyopa bicolor

0.00

Volucella inflata 
Soortnaam
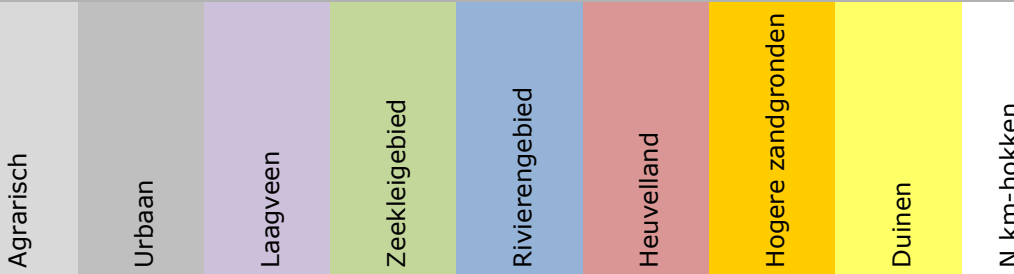

Leucozona laternaria

Epistrophe diaphana

Epistrophella euchroma

Myolepta dubia

Orthonevra brevicornis

Heringia brevidens

0.00

Xanthogramma pedissequum

0.01

0.00

Dasysyrphus pinastri

Cheilosia latifrons

00

0.02

0.02

Mallota fuciformis

Brachyopa insensilis

Trichopsomyia lucida

Pipiza fenestrata

Epistrophe melanostoma

Neoascia obliqua

Meligramma triangulifera

Temnostoma vespiforme

Pyrophaena rosarum

Chrysogaster viduata

Cheilosia cynocephala

Platycheirus manicatus

Platycheirus peltatus

Pipiza noctiluca

Cheilosia chrysocoma

Temnostoma bombylans

Platycheirus scutatus s.l.

Pipiza luteitarsis

Myathropa florea

Melangyna cincta

Dasysyrphus venustus

Brachypalpus laphriformis

Pipiza lugubris

Sphegina sibirica

0.02

0.01

0.01

0.01

0.04

0.06

0.08
0.1
0.08

0.04

0.00

Psilota anthracina

Sphaerophoria fatarum

Ferdinandea cuprea

Epistrophe grossulariae

0.00

Cheilosia impressa

0.00

Paragus haemorrhous

Cheilosia scutellata

Brachyopa pilosa

Neoascia interrupta

Epistrophe flava

Parasyrphus punctulatus

Syrphus nitidifrons

Megasyrphus erratica

Parasyrphus malinellus

Platycheirus perpallidus

Psilota atra

Sphaerophoria virgata

Ceriana conopsoides

Didea alneti

Melangyna quadrimaculata

Brachyopa testacea

Xylota abiens

Parasyrphus lineolus

Cheilosia longula

Xanthogramma stackelbergi

0.00

0.04

0.00

0.07

0.04

0.10

0.08

0.02

$0.05 \quad 0.04$

$0.04 \quad 0.05$

0.02

0.02

0.13

0.05

0.09

$0.03 \quad 0.09$

0.08

0.05

0.01

0.00

0.00

0.02

0.00

0.00

0.00

0.00

ren


Soortnaam

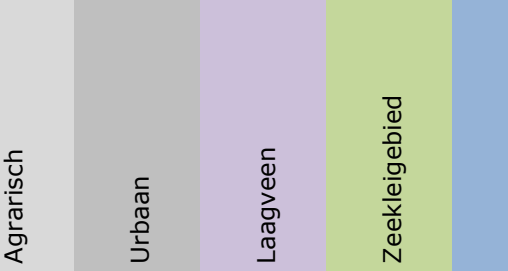

Callicera rufa

Paragus pecchiolii

Chrysotoxum octomaculatum 0.01

Dasysyrphus pauxillus

0.01

Callicera fagesi

Platycheirus discimanus

Microdon myrmicae

Chrysogaster virescens

Volucella bombylans

Dasysyrphus tricinctus

Parasyrphus annulatus

Melangyna lasiophthalma

Chrysotoxum vernale

Pelecocera tricincta

Didea intermedia

Chalcosyrphus piger

Sphaerophoria philanthus

Cheilosia urbana

Chrysotoxum festivum

Eristalinus aeneus

Lejops vittata

Cheilosia mutabilis

Platycheirus immarginatus

Xanthandrus comtus

Platycheirus europaeus

Cheilosia psilophthalma

Melangyna umbellatarum

Cheilosia uviformis

Syrphus torvus

Xylota tarda

Cheilosia bergenstammi

Sphaerophoria batava

Eupeodes lapponicus

Chamaesyrphus lusitanicus

Chalcosyrphus nemorum

Platycheirus angustatus

Xylota sylvarum

Cheilosia pagana

Syrphus ribesii

Xylota segnis

Volucella pellucens

Eristalis nemorum

Syrphus vitripennis

Dasysyrphus albostriatus

Eristalis pertinax

Epistrophe nitidicollis

Cheilosia albipila

Melanostoma scalare

Eristalis similis

Platycheirus ambiguus

Trichopsomyia flavitarsis

Eupeodes nielseni

Cheilosia fraterna

Heringia heringi

Heringia latitarsis

0.00

0.08

0.01

0.00

$0.01 \quad 0.00$

0.06

(2)

$0.06 \quad 85$

$0.19 \quad 73$

$0.10 \quad 7$

$0.10 \quad 11$

$0.09 \quad 6$

$0.09 \quad 109$

0.00

$\begin{array}{ll}0.00 & 0.00\end{array}$

0.00

0.02

$0.00 \quad 0.02$

$0.08 \quad 24$

$0.07 \quad 19$

$0.06 \quad 65$

$0.04 \quad 6$

$\begin{array}{lll}0.00 & 0.00 & 0.04\end{array}$

0.00

$0.03 \quad 0.01$

$0.07 \quad 0.08$

$0.14 \quad 541$

$0.06 \quad 10$

$0.00 \quad 0.00$

0.00

0.09

$\begin{array}{lll}0.03 & 0.05 & 7\end{array}$

0.08

\begin{tabular}{|c|c|c|c|c|c|}
\hline & & & 0.03 & 0.05 & \\
\hline .08 & 0.07 & 0.01 & 0.05 & 0.01 & 237 \\
\hline 0.01 & 0.04 & & 0.04 & 0.01 & 183 \\
\hline
\end{tabular}

\begin{tabular}{|c|c|c|c|c|c|}
\hline 08 & 0.07 & 0.01 & 0.05 & 0.01 & 237 \\
\hline 0.0 & 0.04 & & 0.04 & 0.01 & 183 \\
\hline
\end{tabular}

Parasyrphus vittiger

Chrysotoxum arcuatum

0.00

0.05

0.00

0.02

0.04

0.04

$0.00 \quad 326$

\begin{tabular}{|l|l|l|}
\hline & 0.06 & 0.04 \\
\hline 0.13 & 0.06 & 0.27 \\
\hline
\end{tabular}

0.27

$0.09 \quad 0.03$

0.25

799

0.00

$0.12 \quad 0.01$

0.00

0.06

0.00

0.03

0.01

0.21

$0.07 \quad 1220$

$0.20 \quad 0.04$

0.00

0.10

0.03

$0.03 \quad 1947$

\begin{tabular}{lllllll} 
& 0.03 & 0.10 & 0.07 & 0.00 & 235 \\
\hline
\end{tabular}

\begin{tabular}{llllllll}
0.00 & 0.04 & 0.01 & 0.07 & 0.03 & 0.01 & 207 \\
\hline
\end{tabular}

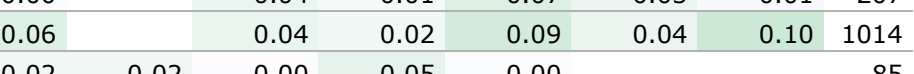

0.02

0.02

$0.00 \quad 0.05$

0.00

$0.02 \quad 0.01$
0.04

0.02

0.01

0.01

Chrysotoxum verralli

0.04

0.02

0.00

0.04

0.02

0.04

13

0.00

0.01

0.00

0.04

0.03

\begin{tabular}{ll}
\hline 0.04 & 13 \\
\hline 0.03 & 70
\end{tabular}

\begin{tabular}{lll}
\hline & 19 \\
\hline 0.04 & 0.02 & 10 \\
\hline
\end{tabular}

\begin{tabular}{rrr}
0.04 & 0.02 & 10 \\
\hline 0.03 & 0.03 & 6 \\
\hline
\end{tabular}

0.01

0.01

0.01

0.03

\begin{tabular}{rr}
0.03 & 6 \\
\hline 0.02 & 20
\end{tabular}

0.03

0.03


Soortnaam

Aantal soorten met $\Phi>0.00$

Aantal soorten met $\Phi>0.05$

Aantal soorten met $\Phi>0.15$

Aantal soorten met $\Phi>0.25$

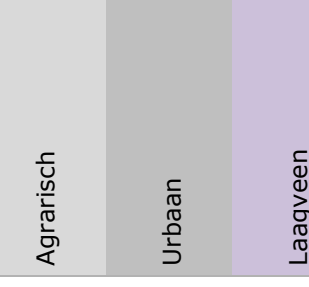

20

$20 \quad 40$

3218

0

14

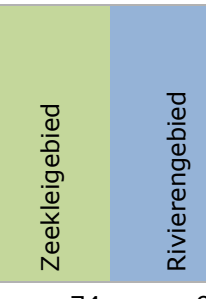

$5 \quad 74$

30

98
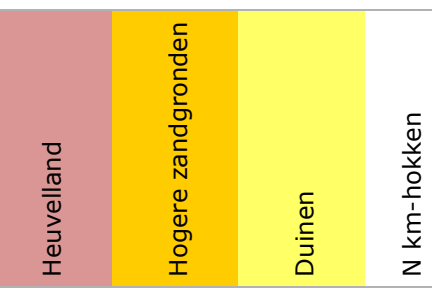

$\begin{array}{llll}3 & 1 & 47\end{array}$

40

\subsection{Belang clusters voor de belangrijkste bestuivers van landbouwgewassen}

Het merendeel van de gewasbestuiving door bijen en zweefvliegen wordt verzorgd door slechts een handjevol soorten (zie § 2.3.2). Vertegenwoordigers uit deze groep van (potentieel) belangrijke gewasbestuivers zijn te vinden in alle landschapstypen, inclusief het agrarisch gebied en het urbaan gebied (Tabel 5 en 6). Het aantal soorten dominante gewasbestuivers per cluster (op basis van $\Phi>0.0$ ) is bij bijen het hoogst in het rivierengebied (met veel fruitteelt), gevolgd door het heuvelland en de soortenrijke subgroepen van het agrarisch gebied en urbaan gebied. Bij zweefvliegen is de soortenrijkdom wat betreft dominante gewasbestuivers het grootst in het urbane gebied, gevolgd door het rivierengebied en het heuvelland. Hierbij moet in het achterhoofd gehouden worden dat de meeste dominante gewasbestuivers generalistische soorten zijn die een relatieve voorkeur hebben voor meerdere landschapstypen.

Vanuit bedrijfseconomisch perspectief is vooral het voorkomen van dominante gewasbestuivers in het agrarisch gebied van belang. Uit de resultaten van de clusteranalyse blijkt dat veel landbouwgebieden arm zijn aan zweefvliegen en met name aan wilde bijen (zie hoofdstuk 3.1). Van het kleine groepje bijensoorten dat nog wél regelmatig voorkomt in intensief gebruikt agrarisch gebied, kan ruim de helft een belangrijke rol kan spelen bij de bestuiving van gewassen. Het gaat hierbij echter slechts om een kleine subset van de belangrijkste gewasbestuivers. Van de 32 belangrijkste gewasbestuivende bijensoorten in Nederland komen slechts 9 soorten relatief vaak voor in intensief gebruikt agrarisch gebied (Tabel 5). Belangrijke gewasbestuivers onder de wilde bijen die ook algemeen voorkomen in intensief gebruikt agrarisch gebied, zijn Aardhommel (Bombus terrestris), Veldhommel (B. lucorum), Steenhommel (B. lapidarius), Akkerhommel (B. pascuorum), Boomhommel (B. hypnorum), Weidehommel (Bombus pratorum), Tuinhommel (Bombus hortorum), Rosse metselbij (Osmia bicornis) en Vosje (Andrena fulva). Van deze soorten heeft de Akkerhommel de hoogste relatieve voorkeur voor het agrarisch gebied (Tabel 3, linkerkolom). Dit is een zeer algemene, generalistische soort die in vrijwel geheel Nederland te vinden is, inclusief grootschalige landbouwgebieden, stedelijk gebied en zeekleipolders. Hoewel de Akkerhommel de meest algemene hommelsoort in Nederland is, zijn de Aardhommel/Veldhommel (B. terrestris/lucorum complex; zie Figuur 6 ) en de Steenhommel ( $B$. lapidarius) op de meeste soorten gewassen als dominante gewasbestuiver aangetroffen, en nemen zij meestal een hogere plek in de rangorde als gewasbestuiver in dan de Akkerhommel. Deze twee soorten zijn op vrijwel elk insectbestoven gewas in Europa aan te treffen (Kleijn et al., 2015). Dominante gewasbestuivers onder de zweefvliegen met een relatief sterke voorkeur voor het agrarisch gebied zijn Snorzweefvlieg (Episyrphus balteatus), Blinde bij (Eristalis tenax), Kegelbijvlieg (Eristalis pertinax; zie Figuur 7) en Gewone driehoekzweefvlieg (Melanostoma mellinum). 


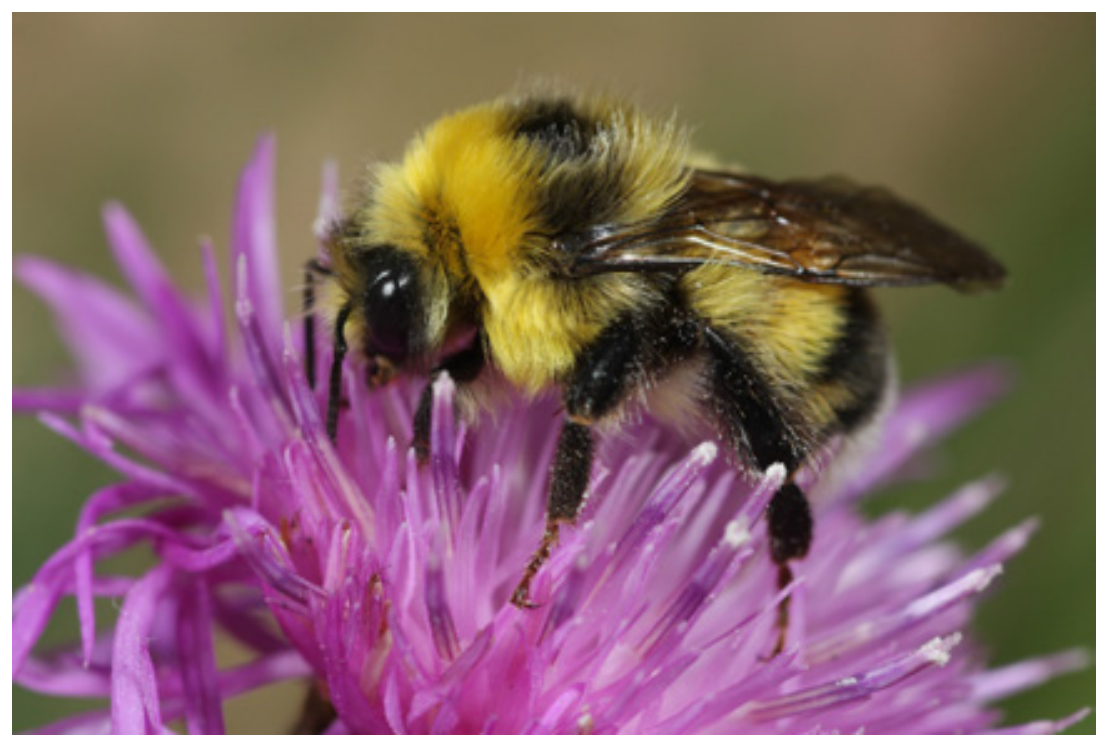

Figuur 6 Voor veel landbouwgewassen zijn hommels uit de Aardhommel/Veldhommel-groep (B. terrestris / lucorum) de dominante bestuivers. Hier de Veldhommel (foto: Tim Faasen).

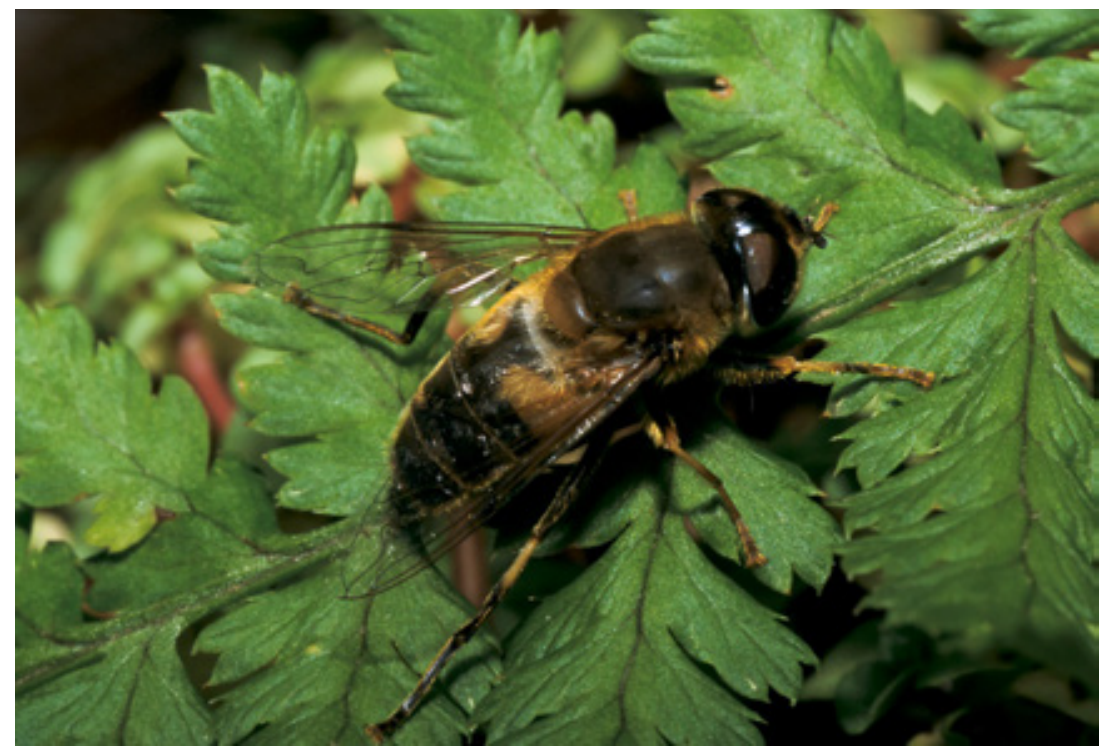

Figuur 7 Bij de zweefvliegen is de Kegelbijvlieg (Eristalis pertinax) een dominante gewasbestuiver (foto: Tim Faasen).

In delen van het agrarisch gebied met iets meer natuurlijke elementen (cluster 'Agrarisch, overgang'), zijn er naast bovengenoemde soorten nog diverse andere soorten die een belangrijke rol in de bestuiving van gewassen kunnen vervullen, zoals Grasbij (Andrena flavipes), Roodgatje (Andrena haemorrhoa), Meidoornzandbij (Andrena carantonica), Goudpootzandbij (Andrena chrysosceles) en Gewone geurgroefbij (Lasioglossum calceatum). Voor verschillende (fruit)gewassen is aangetoond dat een grotere diversiteit aan bestuivers de opbrengst ten goede kan komen (De Groot et al., 2016). Met name in de fruitteelt kunnen de diverse soorten zandbijen (Andrena spec.) een belangrijke bijdrage leveren aan de bestuiving. In Nederlandse appel- en perenboomgaarden nemen soorten als de Grasbij (Andrena flavipes), Roodgatje (Andrena haemorrhoa; zie Figuur 8), Meidoornzandbij (Andrena carantonica) of Goudpootzandbij (Andrena chrysosceles) vaak zelfs meer bloembezoek voor hun rekening dan de Aardhommel/Veldhommel (B. terrestris/lucorum complex), Steenhommel (B. lapidarius) of Akkerhommel (B. pascuorum) en transporteren zij het meeste stuifmeel (Scheper et al., 2014b). Daarnaast bleek uit onderzoek in appelteeltpercelen dat juist de zandbijen (Andrena sp.) duidelijk efficiënter zijn dan de algemene hommelsoorten bij het bestuiven van een bloem: per bezoek laten ze significant meer stuifmeel op de bloem achter (Rusman, 2013). Opvallend is dat een 
flink deel van de in potentie dominante gewasbestuivers een optimum heeft in niet-agrarische landschapstypes (Tabel 5). Voorbeelden van bijensoorten met een iets grotere kieskeurigheid en/of zeldzaamheid zijn Wimperflankzandbij (Andrena dorsata), Donkere klaverzandbij (A. labialis), Bremzandbij ( $A$. ovatula) en Groepjesgroefbij (Lasioglossum malachurum). In het agrarisch gebied kan het voorkomen van een deel van deze soorten waarschijnlijk bevorderd worden met behulp van maatregelen met een wat hoger ambitieniveau (zie § 4.1.2).

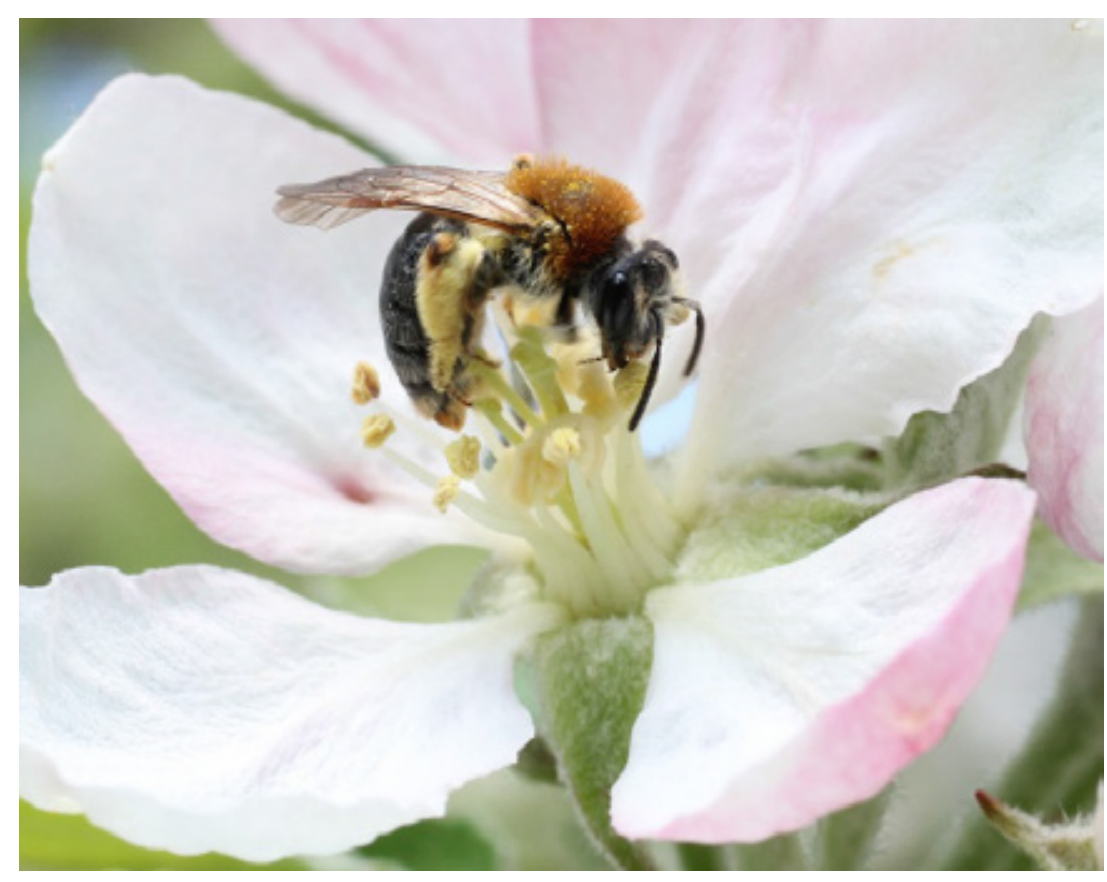

Figuur 8 In de fruitteelt kunnen de diverse soorten zandbijen (Andrena spec.) een belangrijke bijdrage leveren aan de bestuiving. Hier het Roodgatje (Andrena haemorrhoa) foeragerend op appelbloesem (foto: David Kleijn).

Tabel 5 Overzicht van het belang van de landschapstypen voor bedreigde bijensoorten en voor bijen die (in potentie) een belangrijke rol kunnen spelen bij de bestuiving van landbouwgewassen. De tabel geeft zowel het aantal soorten als het percentage ten opzichte van het totaalaantal soorten in het cluster. Alleen soorten met een relatieve voorkeur voor een cluster zijn meegeteld (Phi coefficient of association $>0$ ).

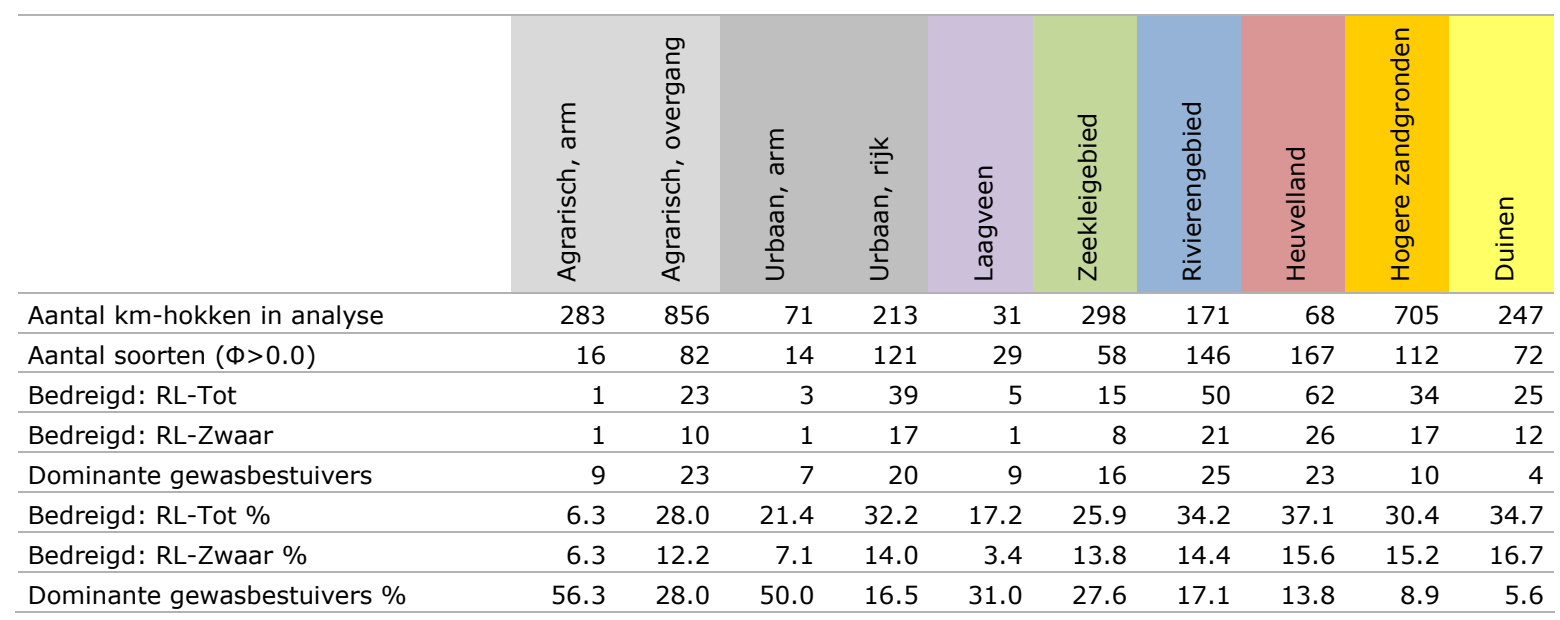


Tabel 6 Overzicht van het belang van de landschapstypen voor bedreigde zweefvliegen en voor soorten die (in potentie) een belangrijke rol kunnen spelen bij de bestuiving van landbouwgewassen. De tabel geeft zowel het aantal soorten als het percentage ten opzichte van het totaalaantal soorten in het cluster. Alleen soorten met een relatieve voorkeur voor een cluster zijn meegeteld (Phi coefficient of association $>0$ ).

\begin{tabular}{|c|c|c|c|c|c|c|c|c|}
\hline & 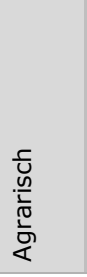 & 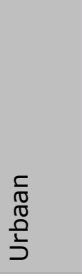 & 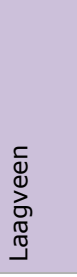 & $\begin{array}{l}\frac{D}{d} \\
\frac{0}{0} \\
\frac{0}{0} \\
\frac{0}{v} \\
\frac{v}{d} \\
\stackrel{\nu}{N}\end{array}$ & $\begin{array}{l}\frac{0}{0} \\
\frac{0}{0} \\
0 \\
\frac{0}{0} \\
\frac{1}{0} \\
\frac{0}{2} \\
\frac{1}{\alpha}\end{array}$ & $\begin{array}{l}\text { D } \\
\frac{1}{0} \\
\overline{\bar{D}} \\
⿱ 亠 䒑 \\
0 \\
\text { I }\end{array}$ & 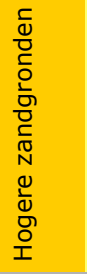 & 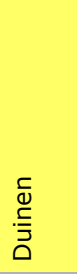 \\
\hline Aantal soorten $(\Phi>0.0)$ & 24 & 93 & 55 & 74 & 98 & 148 & 114 & 93 \\
\hline Bedreigd & 0 & 9 & 4 & 5 & 9 & 19 & 22 & 10 \\
\hline Dominante gewasbestuivers & 10 & 20 & 8 & 15 & 18 & 17 & 7 & 13 \\
\hline Bedreigd \% & 0.0 & 9.7 & 7.3 & 6.8 & 9.2 & 12.8 & 19.3 & 10.8 \\
\hline
\end{tabular}

\subsection{Belang clusters voor bedreigde soorten}

In vergelijking met de groep van dominante gewasbestuivers is de groep met bedreigde soorten veel omvangrijker. Ruim de helft (55\%) van de in Nederland voorkomende bijensoorten verkeert in de gevarenzone en staat vermeld op de recent gepubliceerde Rode Lijst Bijen (Reemer, 2018). Bij zweefvliegen is ongeveer een derde deel van de soorten bedreigd (Reemer et al., 2009), maar voor deze groep is helaas nog geen officiële Rode Lijst beschikbaar. Tabel 5 en 6 geven een overzicht van het voorkomen van bedreigde soorten in de onderscheiden landschapstypen. Het eerste dat hierbij in het oog springt, is dat vrijwel alle onderscheiden landschapstypen bedreigde soorten herbergen. Dit impliceert dat het in alle landschapstypen zinvol kan zijn om maatregelen te nemen voor de bevordering van bedreigde wilde bijen en zweefvliegen. Er zijn bij zowel bijen als zweefvliegen echter wel grote verschillen in het aantal bedreigde soorten per landschapstype, zowel op basis van absolute aantallen als procentueel gezien.

Het landschapstype met de grootste rijkdom aan bedreigde bijensoorten is het heuvelland in Limburg. Van de soorten met een relatieve voorkeur voor dit landschapstype zijn er 62 opgenomen op de Rode Lijst. Dit hoge aantal hangt waarschijnlijk samen met het reliëfrijke landschap, het gevarieerde microklimaat (met warme en droge hellingschraallanden, steilranden, mergelgroeven) en de kalkhoudende bodem. Voorbeelden van bedreigde soorten met een voorkeur voor het heuvelland zijn Knautiabij (Andrena hattorfiana), Zwarte sachembij (Anthophora retusa), Zuidelijke langhoornbij (Eucera nigrescens; zie Figuur 9), Waaiergroefbij (Lasioglossum pallens) en Kleine groefbij (Lasioglossum parvulum). Op de tweede plaats volgt het rivierengebied met 50 Rode Lijst-soorten. Dit hangt waarschijnlijk samen met de variatie aan bodemtypen en biotopen, inclusief dynamische pioniermilieus, bloemrijke dijken en rivierbegeleidende bossen. Rode Lijst-soorten met een relatieve voorkeur voor het rivierengebied zijn Donkere rimpelrug (Andrena bimaculata; zie Figuur 10), Steilrandgroefbij (Lasioglossum quadrinotatulum), Bonte wespbij (Nomada bifasciata) en Donkere klaverzandbij (Andrena labialis). De laatste twee soorten komen ook relatief veel voor in het heuvelland. Indien niet gekeken wordt naar het absolute aantal soorten, maar naar het percentage ten opzichte van het totaal aantal soorten binnen het landschapstype, dan neemt het duingebied een tweede plaats in, net na het heuvelland. Bedreigde soorten met een voorkeur voor het duingebied zijn onder andere Kustbehangersbij (Megachile maritima; zie Figuur 11), Zilveren zandbij (Andrena argentata) en Geelgespoorde houtmetselbij (Hoplitis claviventris). Bij de zweefvliegen springen vooral de hogere zandgronden (op plek één) en het heuvelland er in positieve zin uit qua rijkdom aan bedreigde soorten. 


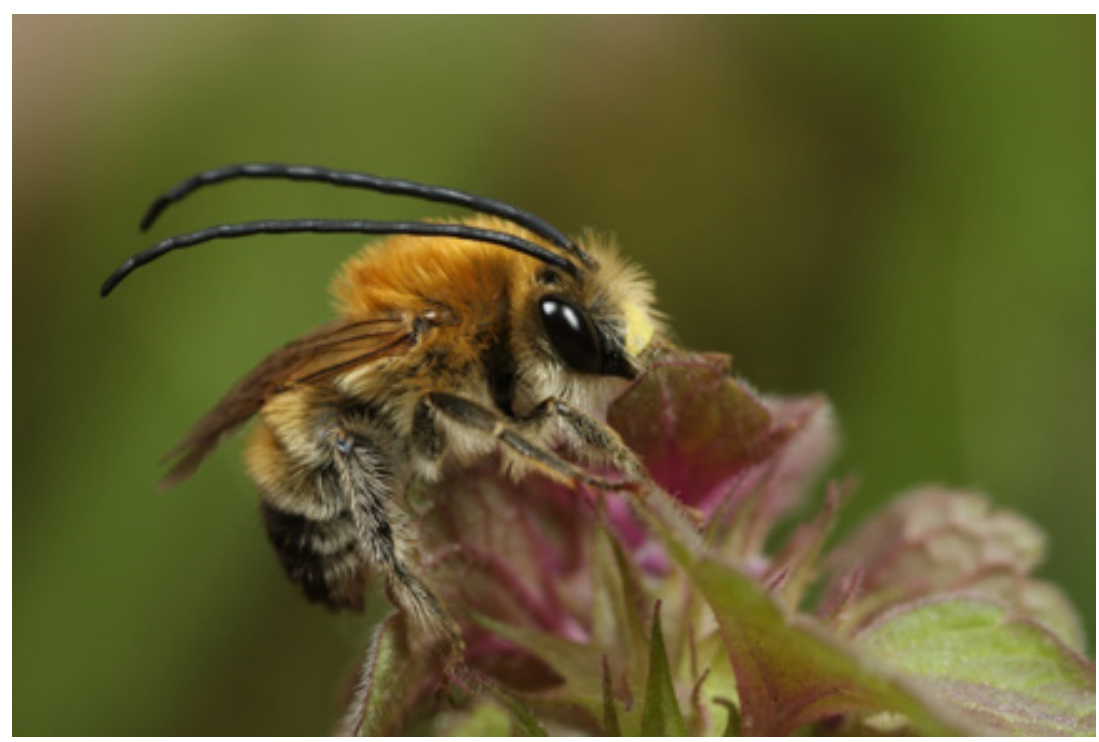

Figuur 9 De zeer zeldzame Zuidelijke langhoornbij (Eucera nigrescens) heeft een voorkeur voor het heuvelland. Vrouwtjes van de soort verzamelen uitsluitend stuifmeel op vlinderbloemigen en zijn daardoor afhankelijk van bloemrijke graslanden en bosranden (foto: Tim Faasen).

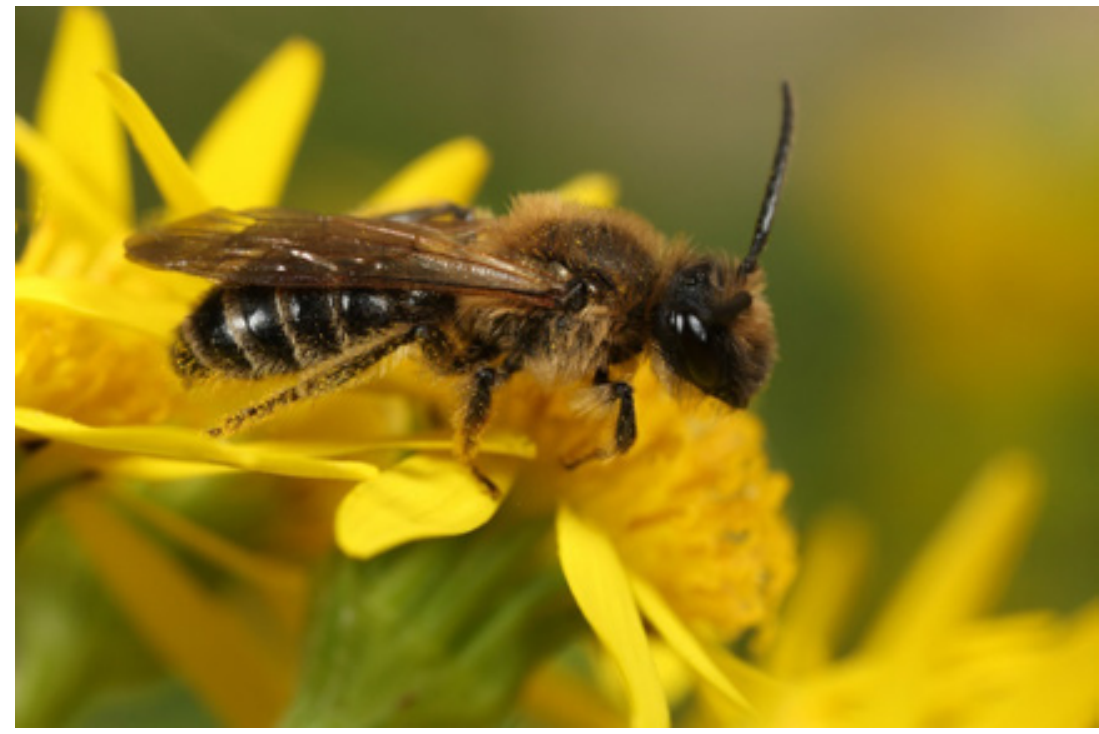

Figuur 10 De zeldzame Donkere rimpelrug (Andrena bimaculata) leeft in zandige en lemige gebieden en komt tegenwoordig vooral voor in het rivierengebied (foto: Tim Faasen). 


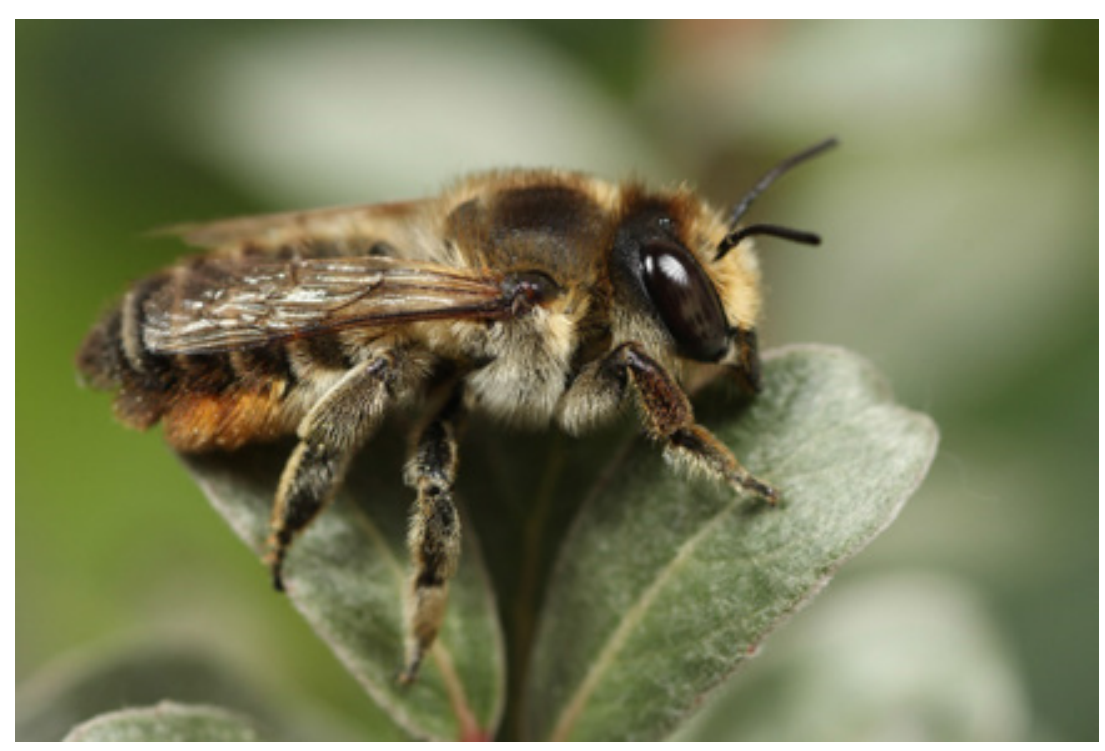

Figuur 11 De Kustbehangersbij (Megachile maritima) is gebonden aan open, droge, bloemrijke habitats. In het binnenland is de soort zeer sterk achteruitgegaan en de resterende populaties bevinden zich vrijwel uitsluitend in het duingebied (foto: Tim Faasen).

Ook het urbane gebied is opvallend rijk aan bedreigde soorten. Bijensoorten waarvoor het stedelijk gebied relatief belangrijk is (cluster 'urbaan, rijk'), zijn Blauwe metselbij (Osmia caerulescens; zie Figuur 12), Glimmende smaragdgroefbij (Lasioglossum nitidulum) en Gewone tubebij (Stelis breviuscula). In het urbane gebied komen dus duidelijk meer bedreigde bijensoorten voor dan in het landelijke gebied. Dit hangt mogelijk samen met de grotere beschikbaarheid van voedsel in tuinen, de grotere beschikbaarheid van kunstmatige nestelgelegenheid en de lagere blootstelling aan gewasbeschermingsmiddelen. Verder blijkt uit Brits onderzoek dat hommels in de stad meer nakomelingen krijgen, langer leven en grotere kolonies vormen dan in aangrenzende landbouwgebieden (Samuelson et al., 2018). Meer inzicht in de achterliggende factoren kan handvaten bieden voor herstelmaatregelen (zie § 4.2). Ook voor enkele zeldzame en bedreigde zweefvliegen kunnen urbane en ruderale gebieden van belang zijn, waaronder Kortlijfplatbek (Triglyphus primus) en Krulhaarplatvoetje (Platycheirus ambiguus).

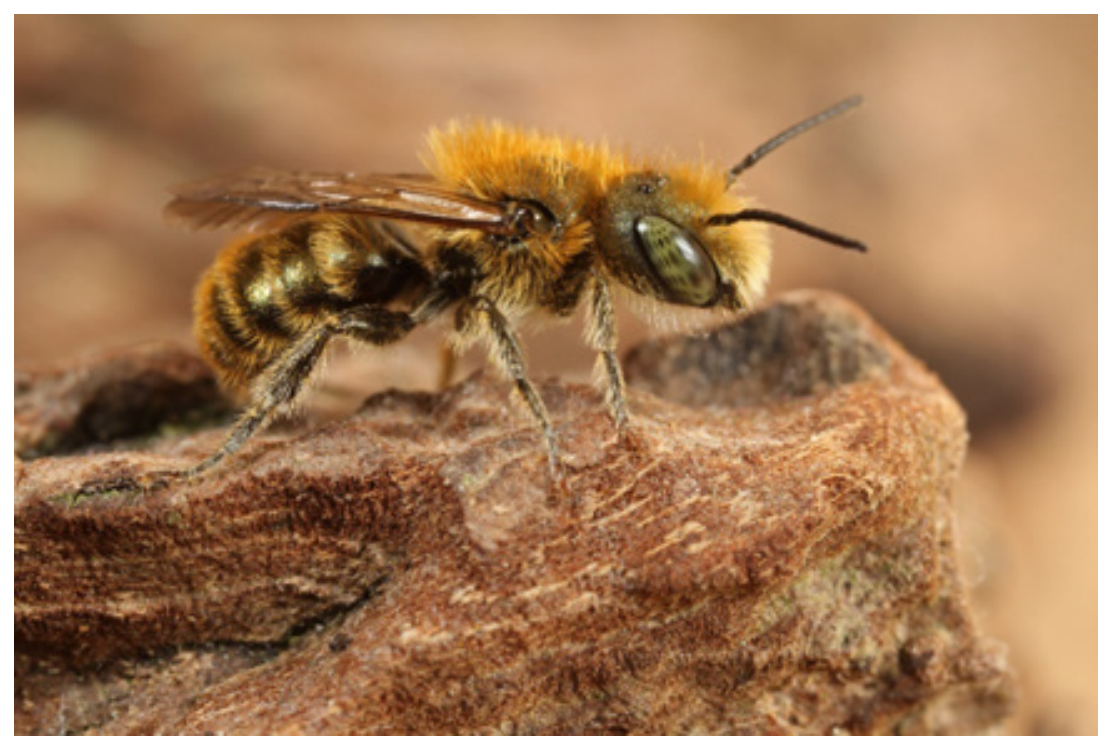

Figuur 12 De Blauwe metselbij (Osmia caerulescens) komt relatief vaak voor in bloemrijke tuinen in urbaan gebied (foto: Tim Faasen). 
Binnen de soortenarme landschapstypen zijn er geen bedreigde zweefvliegen die een relatieve voorkeur hebben voor het agrarisch gebied (Tabel 6). Bij de bijen herbergen de soortenarme clusters in het agrarisch en stedelijk gebied slechts enkele soorten van de Rode Lijst. Een voorbeeld wordt gevormd door de zeldzame Blauwzwarte houtbij (Xylocopa violacea). Deze soort komt in allerlei habitattypen voor, waaronder parken en tuinen, maar is voor de bouw van nesten afhankelijk van dood hout op zonnige plekken. De sterke afname hangt mogelijk samen met de verminderde beschikbaarheid van geschikte nestplaatsen in het stedelijk gebied (Reemer, 2018). Uit oude waarnemingen blijkt dat een deel van de bedreigde soorten vroeger ook in het agrarisch gebied een ruimere verspreiding hadden. Dit geldt met name voor soorten van bloemrijke graslanden, zoals Paardenbloembij (Andrena humilis), Donkere klaverzandbij (A. labialis), Gewone langhoornbij (Eucera longicornis), Kleine bandgroefbij (Lasioglossum quadrinotatum), Grashommel (Bombus ruderarius; zie Figuur 13) en de uit Nederland verdwenen Donkere tuinhommel (Bombus subterraneus). Door de schaalvergroting zijn bloemrijke graslanden in het agrarisch gebied zeldzaam geworden en deze soorten zijn tegenwoordig grotendeels teruggedrongen tot natuurreservaten en gebieden met een hoog aandeel aan natuurlijke elementen.

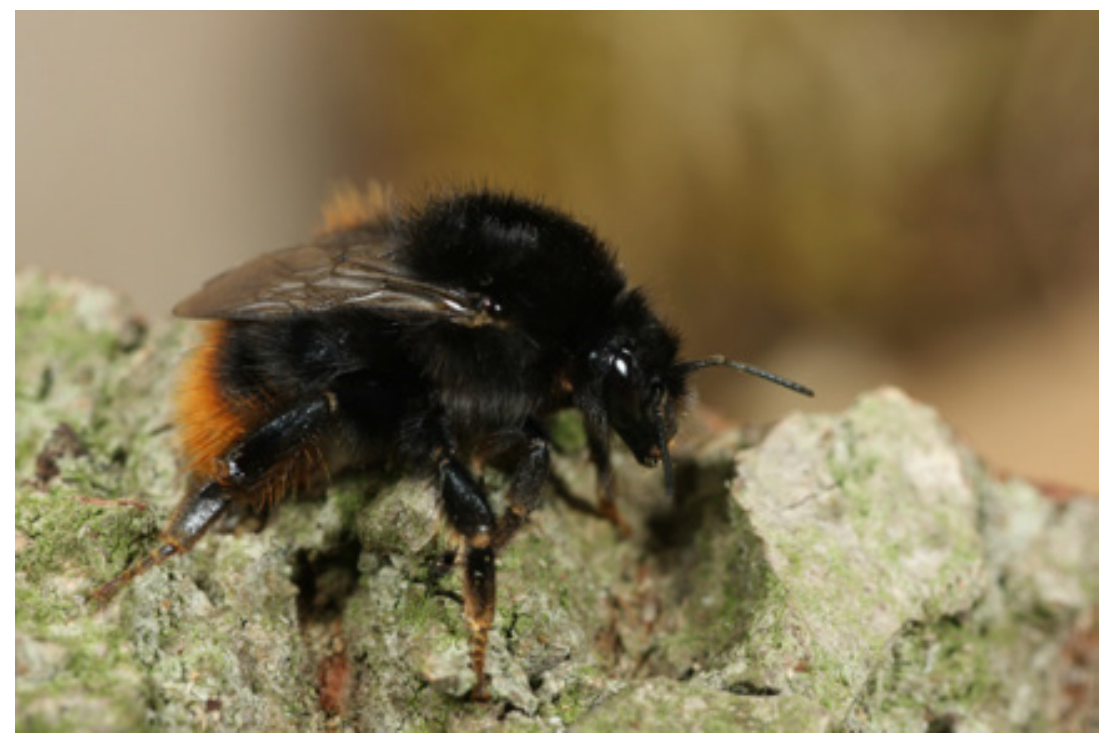

Figuur 13 De Grashommel (Bombus ruderarius) had in het agrarisch gebied in de eerste helft van de vorige eeuw een veel ruimere verspreiding (foto: Tim Faasen). 


\section{$4 \quad$ Toepassingsmogelijkheden}

\subsection{Gebruik van de tabellen met soorten per landschapstype}

\subsubsection{Mogelijkheden en beperkingen}

De resultaten in dit rapport zijn bedoeld als een hulpmiddel waarmee gebruikers snel kunnen inzoomen op de relevante soorten bestuivers in een bepaalde beheersregio, om vervolgens gerichte maatregelen te kunnen nemen die aansluiten bij de eisen die deze soorten aan hun omgeving stellen. De resultaten vormen hiermee tevens de basis voor de volgende fase in deze module: het specificeren van ecologische randvoorwaarden van bestuivers ten aanzien van voedselplanten en de (micro)biotoop voor voortplanting (met daarbij ook aangegeven welke kennishiaten er nog zijn) en het identificeren van effectieve maatregelen. Verschillende soortengroepen zullen immers andere eisen stellen, en dus ook andere maatregelen vergen.

Bij de interpretatie van de tabellen met bijen en zweefvliegen per landschapstype (Tabel 3 en 4 ) is het goed om een paar aandachtspunten in het achterhoofd te houden:

- De tabellen geven per soort informatie over de landschapstypen (clusters) waarvoor de soort een relatieve voorkeur heeft. In deze landschappen kunnen de soorten het efficiëntst behouden of bevorderd worden. In de tabellen betekenen lege cellen niet per se dat de soort niet voorkomt, maar dat de soort een voorkeur heeft voor andere landschapstypen. Omgekeerd geldt voor zeldzame soorten vrijwel zonder uitzondering dat ze ook in het landschap waar hun optimum ligt in de meeste gebieden afwezig zijn, bijvoorbeeld omdat ze gebonden zijn aan specifieke, weinig voorkomende (micro)biotopen of omdat ze een geringe mobiliteit hebben. De tabellen geven vooral inzicht in de soorten die in potentie te verwachten zijn in een bepaald landschapstype.

- De resultaten zijn gebaseerd op recente verspreidingsgegevens (2002-2016) om daarmee zo goed mogelijk aan te sluiten bij actuele informatie over omgevingsfactoren (met name van belang voor landgebruik). Voor sommige soorten met een sterke achteruitgang geldt dat ze vroeger in Nederland een ruimere spreiding hadden over de onderscheiden landschapstypen. De achteruitgang in deze landschapstypen hangt in veel gevallen samen met de intensivering van het landgebruik. Voor dergelijke soorten geeft de tabel vooral een beeld van het landschapstype waarin ze tegenwoordig een refugium vinden. Een voorbeeld is de Zandhommel (Bombus veteranus) die vroeger een ruime verspreiding had, inclusief het binnenland. De Zandhommel is de afgelopen decennia zeer sterk achteruitgegaan en is tegenwoordig vrijwel beperkt tot het zeekleigebied in de Zuid-Hollandse delta (Smit, 2016). Een vergelijkbaar verhaal geldt voor de Grashommel (Bombus ruderarius; zie Figuur 13). Voor diverse soorten met een voorkeur voor zandige of lemige bodems geldt dat ze sterker achteruitgegaan zijn op de verzuringsgevoelige hogere zandgronden in het binnenland dan in de duinen, het rivierengebied en/of het heuvelland, zoals Moshommel (Bombus muscorum), Ruige behangersbij (Megachile circumcincta), Zwarte sachembij (Anthophora retusa), Koolzwarte zandbij (Andrena pilipes) en de vrijwel uit Nederland verdwenen Late hommel (Bombus soroeensis). De achterliggende mechanismen zijn in veel gevallen nog onvoldoende bekend (Reemer, 2018).

- Bij de interpretatie van de clusters voor zweefvliegen moet in het achterhoofd gehouden worden dat de volwassen stadia en de larven vaak andere eisen stellen ten aanzien van hun leefomgeving. Volwassen stadia zijn het opvallendst, maar de (micro)biotoop van larven heeft in veel gevallen waarschijnlijk veel meer invloed op verspreidingspatronen (Sommaggio, 1999; Reemer et al., 2009).

- De informatie over de mate van aanwezigheid van zeldzame soorten in specifieke landschapstypen is over het algemeen minder nauwkeurig (af te leiden uit de kolom 'N km-hokken').

- Voor soorten met een hoge mobiliteit is de binding aan een bepaald landschapstype lastiger vast te stellen, zodat voor dergelijke soorten de mate van voorkeur voor bepaalde landschapstypen mogelijk onderschat wordt. Dit geldt met name voor zweefvliegen die regelmatig zwerven of migreren (Ssymank, 2001; Reemer et al., 2009). 


\subsubsection{Verschillende ambitieniveaus}

Bij de interpretatie van het belang van de onderscheiden landschapstypen voor bestuivende insecten is in hoofdstuk 3 onderscheid gemaakt tussen bedreigde soorten en soorten die in potentie een belangrijke rol kunnen spelen bij de bestuiving van landbouwgewassen ('dominante gewasbestuivers'). Het eerste aspect is vooral van belang voor het behoud van biodiversiteit in Nederland, terwijl het tweede aspect van belang is voor de levering van ecosysteemdiensten. De betreffende soorten zijn in Tabel 3 en 4 gemarkeerd en bij een vergelijking van de soorten valt op dat beide groepen nauwelijks overlap vertonen. De groep met gewasbestuivers en bedreigde soorten verschilt ook sterk in de mate van voorkomen in de verschillende landschapstypen, waarbij vooral de verschillen in het agrarisch gebied in het oog springen.

In grote delen van het agrarisch gebied is het aantal soorten bijen en zweefvliegen zeer gering (Tabel 3 en 4, linker kolom). Er zijn slechts enkele soorten waarvan het zwaartepunt van het voorkomen in het agrarisch gebied ligt, zoals de Akkerhommel (Bombus pascuorum), de Snorzweefvlieg (Episyrphus balteatus) en de Blinde bij (Eristalis tenax). Daarnaast zijn er nog een paar soorten die hun optimum in andere landschapstypen hebben, maar die nog wel relatief veel voorkomen in het agrarisch gebied. Dit kleine groepje omvat de belangrijkste gewasbestuivende soorten. Het gaat hierbij vaak om generalistische soorten die weinig eisen stellen aan hun leefomgeving. In vergelijking met de andere clusters wordt het agrarisch gebied vooral negatief gekenmerkt door het (vrijwel) ontbreken van een groot deel van de soorten. Met name bedreigde soorten die vaak kieskeurig zijn ten aanzien van specifieke milieucondities ontbreken in het agrarisch gebied. Een deel van de bedreigde soorten had vroeger ook in het agrarisch gebied een ruimere verspreiding en is tegenwoordig grotendeels teruggedrongen tot natuurreservaten en gebieden met een hoog aandeel aan natuurlijke elementen. De afname van de soortenrijkdom in het agrarisch gebied hangt waarschijnlijk samen met een complex van deels samenhangende factoren: de achteruitgang van aantallen bloeiende planten, de intensivering in de landbouw, het verdwijnen van geschikte (micro)biotopen voor de voortplanting (zoals onverharde paden, bosjes, houtwallen, overhoekjes en poelen) en het (onjuiste) gebruik van gewasbeschermingsmiddelen worden o.a. genoemd als oorzaken (Biesmeijer et al., 2006; Peeters et al., 2012; Scheper et al., 2014a; Kleijn et al., 2018; Reemer, 2018), al is het relatieve belang van deze factoren nog onvoldoende bekend. De intensivering en schaalvergroting van de landbouw hebben in veel gebieden geleid tot een vervlakking van het landschap: overal ontstond meer van hetzelfde. De variatie in omgevingsfactoren die zorgt voor duidelijke verschillen in het spectrum aan bestuivers tussen de fysisch-geografische regio's wordt in deze agrarische gebieden als het ware overschaduwd door het intensieve landgebruik. In iets mindere mate geldt dit ook voor de bebouwde omgeving.

De toegenomen uniformiteit van bestuivers in grote delen van het land betekent echter niet dat er geen mogelijkheden zijn om het tij te keren. De vraag is dan waar je op inzet als het gaat om effectieve maatregelen voor het bevorderen van bestuivers. Het kan nuttig zijn om hierbij onderscheid te maken tussen verschillende ambitieniveaus op basis van het landgebruik in de omgeving en de speelruimte voor aanpassingen van inrichting en beheer:

- In gebieden die gedomineerd worden door grootschalige, intensieve landbouw met weinig natuurlijke elementen kunnen eenvoudige maatregelen, zoals het inzaaien van inheemse bloemenmengsels, in potentie al gunstig zijn voor het handjevol soorten bijen en zweefvliegen in het cluster 'agrarisch gebied'. Vooral algemene, generalistische soorten zullen hiervan profiteren, waaronder ook diverse belangrijke gewasbestuivers. In soortenarme gebieden kan een kleine vergroting van de diversiteit aan bloembezoekende insectensoorten de opbrengst van verschillende (fruit)gewassen al ten goede komen (zie § 2.3.2).

- Wanneer in het agrarisch gebied gekozen wordt voor een hoger ambitieniveau, dan kunnen ook soorten profiteren die iets kieskeuriger zijn en die kenmerkend zijn voor het landschapstype waarin het gebied valt. Dit leidt tot een hogere diversiteit aan (potentiële) gewasbestuivers en helpt om de oorspronkelijke bestuivende fauna van dit landschap te behouden en bevorderen, inclusief diverse bedreigde soorten. Het relevante landschapstype kan vastgesteld worden met behulp van de kaart in $\S 3.1 .2$. De vraag is nog even of uitvoering van dat soort maatregelen in de buurt van 
bronpopulaties de effectiviteit vergroot wat betreft de meer kieskeurige soorten. Dit is momenteel onderwerp van ander onderzoek in het kader van de Kennisimpuls Bestuivers (module 09).

- Veel bedreigde soorten stellen strenge eisen aan hun leefomgeving en komen vrijwel uitsluitend voor in natuurgebieden en in gebieden met een hoog aandeel aan natuurlijke elementen. Het gaat hierbij bijvoorbeeld om randvoorwaarden ten aanzien van voedselplanten (m.n. bijen), nestgelegenheid (bijen), de gastheer voor larven (broedparasieten: koekoeksbijen en enkele zweefvliegen) en de aanwezigheid van speciale microbiotopen voor de larven van zweefvliegen (zie $\S 4.2)$. Voor het behoud en herstel van deze soorten is daarom maatwerk nodig en in veel gevallen zijn voor duurzame populaties grotere gebieden vereist, met mozaïeken of gradiënten van verschillende habitattypen en met voldoende ruimtelijke samenhang tussen de leefgebieden.

\subsection{Vervolg: Clusters als kader voor specificering ecologische randvoorwaarden}

De onderscheiden clusters zijn gebaseerd op verspreidingsgegevens met een vrij grove resolutie. Binnen de onderscheiden clusters komen daardoor bijen en zweefvliegen voor met een breed palet aan ecologische randvoorwaarden. Het specificeren van deze randvoorwaarden, met daaraan gekoppeld vuistregels voor maatregelen, betreft een vervolgonderzoek dat momenteel gaande is (zie $\S 1.2)$. De onderscheiden landschapstypen vormen daarbij een ruimtelijk kader om in te kunnen zoomen op de relevante soorten per regio (zie de kaart in $\S 3.1 .2$ ).

Binnen de onderscheiden landschapstypen hebben soorten vaak een voorkeur voor specifieke ecologische condities. Twee belangrijke factoren hierbij zijn de beschikbaarheid van bloemen van specifieke plantensoorten (waardplanten waarop bijen en zweefvliegen zich voeden met stuifmeel en/of nectar) en de beschikbaarheid van geschikte locaties voor de afzet van eieren en aansluitend de groei van larven. Voor beide factoren geldt dat soorten onderling sterk verschillen in hun wensen, zodat maatwerk vereist is. Daarnaast spelen nog andere factoren een rol, zoals het microklimaat, beschutting tegen vijanden (predatoren) en de ruimtelijke samenhang van de leefgebieden op landschapsschaal. De ecologische randvoorwaarden en maatregelen om aan deze randvoorwaarden tegemoet te komen, worden in de tweede fase van deze module nader uitgewerkt. Overigens geldt voor een deel van de zeldzame en/of bedreigde soorten dat de ecologische randvoorwaarden nog onvoldoende bekend zijn (Reemer et al., 2009; Potts et al., 2015; Reemer, 2018). 


\section{Literatuur}

Albrecht, M., Schmid, B., Hautier, Y. \& Muller, C.B. 2012. Diverse pollinator communities enhance plant reproductive success. Proceedings of the Royal Society B-Biological Sciences 279: 4845-4852.

Biesmeijer, J.C., Roberts, S.P.M., Reemer, M., Ohlemuller, R., Edwards, M., Peeters, T., Schaffers, A.P., Potts, S.G., Kleukers, R., Thomas, C.D., Settele, J. \& Kunin, W.E. 2006. Parallel declines in pollinators and insect-pollinated plants in Britain and the Netherlands. Science 313: 351-354.

De Caceres, M., Legendre, P. \& Moretti, M. 2010. Improving indicator species analysis by combining groups of sites. Oikos 119: 1674-1684.

De Groot, G.A., Knoben, N., van Kats, R., Dimmers, W., van't Zelfde, M., Reemer, M., Biesmeijer, K. \& Kleijn, D. 2016. De bijdrage van (wilde) bestuivers aan een hoogwaardige teelt van peren en aardbeien : nieuwe kwantitative inzichten in de diensten geleverd door bestuivende insecten aan de fruitteeltsector in Nederland. Alterra Wageningen UR, Wageningen.

De Groot, G.A., van Kats, R., Reemer, M., van der Sterren, D., Biesmeijer, J.C. \& Kleijn, D. 2015. De bijdrage van (wilde) bestuivers aan de opbrengst van appels en blauwe bessen : kwantificering van ecosysteemdiensten in Nederland. Alterra Wageningen UR, Wageningen.

De Waal, R.W. 2007. Fysiotopen van Nederland : een nieuwe standplaatsindeling op basis van abiotische kenmerken. Stratiotes: 14-24.

De Waal, R.W. 1995. Landschapsecologische kartering van Nederland : landschap. Toelichting bij het databestand Landschap van het LKN - project. SC-DLO, Wageningen.

Dufrene, M. \& Legendre, P. 1997. Species assemblages and indicator species: The need for a flexible asymmetrical approach. Ecological Monographs 67: 345-366.

Fijen, T.P.M., Scheper, J.A., Boom, T.M., Janssen, N., Raemakers, I. \& Kleijn, D. 2018. Insect pollination is at least as important for marketable crop yield as plant quality in a seed crop. Ecology Letters: 21: 1704-1713.

Garibaldi, L.A., Steffan-Dewenter, I., Winfree, R., Aizen, M.A., Bommarco, R., Cunningham, S.A., Kremen, C., Carvalheiro, L.G., Harder, L.D., Afik, O., Bartomeus, I., Benjamin, F., Boreux, V., Cariveau, D., Chacoff, N.P., Dudenhöffer, J.H., Freitas, B.M., Ghazoul, J., Greenleaf, S., Hipólito, J., Holzschuh, A., Howlett, B., Isaacs, R., Javorek, S.K., Kennedy, C.M., Krewenka, K.M., Krishnan, S., Mandelik, Y., Mayfield, M.M., Motzke, I., Munyuli, T., Nault, B.A., Otieno, M., Petersen, J., Pisanty, G., Potts, S.G., Rader, R., Ricketts, T.H., Rundlöf, M., Seymour, C.L., Schüepp, C., Szentgyörgyi, H., Taki, H., Tscharntke, T., Vergara, C.H., Viana, B.F., Wanger, T.C., Westphal, C., Williams, N. \& Klein, A.M. 2013. Wild Pollinators Enhance Fruit Set of Crops Regardless of Honey Bee Abundance. Science 339: 1608-1611.

Gies, T.J.A., van Os, J., Smidt, R.A., Naeff, H.S.D. \& Vos, E.C. 2015. Geografisch Informatiesysteem Agrarische Bedrijven (GIAB) : gebruikershandleiding 2010. Wettelijke Onderzoekstaken Natuur \& Milieu, Wageningen.

Goulson, D., Nicholls, E., Botias, C. \& Rotheray, E.L. 2015. Bee declines driven by combined stress from parasites, pesticides, and lack of flowers. Science 347.

Hill, M.O. \& Šmilauer, P. 2005. TWINSPAN for Windows version 2.3. Centre for Ecology and Hydrology \& University of South Bohemia, Huntingdon \& Ceske Budejovice.

Kemmers, R.H., van Delft, S.P.J., van Riel, M.C., Hommel, P.W.F.M., Jansen, A.J., Klaver, B., Loeb, R., Runhaar, J. \& Smeenge, H. 2011. Landschapssleutel : een leidraad voor een landschapsanalyse. Alterra, Wageningen.

Kleijn, D., Bink, R.J., Braak, C.J.F.t., Grunsven, R.v., Ozinga, W.A., Roessink, I., Scheper, J.A., Schmidt, A.M., Wallis de Vries, M.F., Wegman, R., Zee, F.F.v.d. \& Zeegers, T. 2018. Achteruitgang insectenpopulaties in Nederland: trends, oorzaken en kennislacunes. Wageningen Environmental Research, Wageningen.

Kleijn, D., Winfree, R., Bartomeus, I., Carvalheiro, L.G., Henry, M., Isaacs, R., Klein, A.-M., Kremen, C., M'Gonigle, L.K., Rader, R., Ricketts, T.H., Williams, N.M., Lee Adamson, N., Ascher, J.S., Baldi, A., Batary, P., Benjamin, F., Biesmeijer, J.C., Blitzer, E.J., Bommarco, R., Brand, M.R., Bretagnolle, V., Button, L., Cariveau, D.P., Chifflet, R., Colville, J.F., Danforth, B.N., Elle, E., Garratt, M.P.D., Herzog, F., Holzschuh, A., Howlett, B.G., Jauker, F., Jha, S., Knop, E., 
Krewenka, K.M., Le Feon, V., Mandelik, Y., May, E.A., Park, M.G., Pisanty, G., Reemer, M., Riedinger, V., Rollin, O., Rundlof, M., Sardinas, H.S., Scheper, J., Sciligo, A.R., Smith, H.G., Steffan-Dewenter, I., Thorp, R., Tscharntke, T., Verhulst, J., Viana, B.F., Vaissiere, B.E., Veldtman, R., Westphal, C. \& Potts, S.G. 2015. Delivery of crop pollination services is an insufficient argument for wild pollinator conservation. Nature Communications 6: 7414.

Kramer, H., Clement, J. \& de Knegt, B. 2013. Basiskaart Natuur 2004 : van versie 1.0 naar 3.1. Wettelijke Onderzoekstaken Natuur \& Milieu, Wageningen.

Kramer, H., Hazeu, G.W. \& Clement, J. 2007. Basiskaart Natuur 2004 : vervaardiging van een landsdekkend basisbestand terrestrische natuur in Nederland. Wettelijke Onderzoekstaken Natuur \& Milieu, Wageningen.

Legendre, P. \& Legendre, L. 2012. Numerical ecology. Elsevier, Amsterdam.

McCune, B., Grace, J.B. \& Urban, D.L. 2002. Analysis of ecological communities. MjM Software Design, Gleneden Beach, OR.

Meyer, B., Jauker, F. \& Steffan-Dewenter, I. 2009. Contrasting resource-dependent responses of hoverfly richness and density to landscape structure. Basic and Applied Ecology 10: 178-186.

Ministerie van LNV 2018. Nationale Bijenstrategie Bed \& Breakfast for Bees. Ministerie van Landbouw, Natuur en Voedselkwaliteit, Den Haag.

Nieto, A., Roberts, S.P.M., Kemp, J., Rasmont, P., Kuhlmann, M., García Criado, M., Biesmeijer, J.C., Bogusch, P., Dathe, H.H., De la Rúa, P., De Meulemeester, T.D., M., Dewulf, A., Ortiz-Sánchez, F.J., Lhomme, P., Pauly, A., Potts, S.G., Praz, C., Quaranta, M., Radchenko, V.G., Scheuchl, E., Smit, J., Straka, J., Terzo, M., Tomozii, B., Window, J. \& Michez, D. 2014. European Red List of bees, Luxembourg.

Ollerton, J., Winfree, R. \& Tarrant, S. 2011. How many flowering plants are pollinated by animals? Oikos 120: 321-326.

Peeters, T.M.J., Nieuwenhuijsen, H., Smit, J., van der Meer, F., Raemakers, I.P., Heitmans, W.R.B., van Achterberg, C., Kwak, M., Loonstra, A.J., de Rond, J., Roos, M. \& Reemer, M. 2012. De Nederlandse bijen (Hymenoptera: Apidae S.L.). Natuur van Nederland 11, Naturalis Biodiversity Center \& European Invertebrate Survey - Nederland, Leiden, Leiden.

Potts, S., Biesmeijer, K., Bommarco, R., Breeze, T., Carvalheiro, L., Franze, Gonza, lez-Varo, J.P., Holzschuh, A., Kleijn, D., Klein, A.M., Kunin, Lecocq, T., Lundin, O., Michez, D., Neumann, P., Nieto, A., Penev, L., Rasmont, P., Ratama, ki, O., Riedinger, V., Roberts, S.P.M., Rundlo, f, M., Scheper, J. \& Sørensen, P. 2015. Status and trends of European pollinators: key findings of the STEP project. Pensoft Publishers, Sofia.

Potts, S.G., Biesmeijer, J.C., Kremen, C., Neumann, P., Schweiger, O. \& Kunin, W.E. 2010. Global pollinator declines: trends, impacts and drivers. Trends in Ecology \& Evolution 25: 345-353.

Reemer, M. 2018. Basisrapport voor de Rode Lijst Bijen. EIS Kenniscentrum Insecten, Leiden.

Reemer, M. \& Kleijn, D. 2012. Wilde bestuivers in appel- en perenboomgaarden in de Betuwe in 2010 en 2011. Rapportnummer EIS2012-01. Stichting European Invertebrate Survey - Nederland.

Reemer, M., Renema, W., Van Steenis, W., Barendregt, A., Smit, J.T., Van Veen, M.P., Van Steenis, J. \& Van der Leij, L.J.J.M. 2009. De Nederlandse zweefvliegen (Diptera: Syrphidae). Nederlandse fauna 8; Nationaal Natuurhistorisch Museum Naturalis, KNNV Uitgeverij, European Invertebrate Survey - Nederland, Leiden.

Rusman, Q.S. 2013. Pollination effectiveness of wild and domesticated pollinators on apple, Malus domestica. MSc thesis, Wageningen University, WUR.

Samuelson, A.E., Gill, R.J., Brown, M.J.F. \& Leadbeater, E. 2018. Lower bumblebee colony reproductive success in agricultural compared with urban environments. Proceedings of the Royal Society B: Biological Sciences 285: 20180807.

Schaminée, J.H.J., Hennekens, S.M. \& Ozinga, W.A. 2007. Use of the ecological information system SynBiosys for the analysis of large datasets. Journal of Vegetation Science 18: 463-470.

Scheper, J., Kleijn, D. \& Reemer, M. 2011. De relevantie van wilde bijen voor de bestuiving van landbouwgewassen. De Levende Natuur 112: 124-125.

Scheper, J., Reemer, M., van Kats, R., Ozinga, W.A., van der Linden, G.T.J., Schaminée, J.H.J., Siepel, H. \& Kleijn, D. 2014a. Museum specimens reveal loss of pollen host plants as key factor driving wild bee decline in The Netherlands. Proceedings of the National Academy of Sciences 111: 17552-17557.

Scheper, J.A., van Kats, R.J.M., Reemer, M. \& Kleijn, D. 2014b. Het belang van wilde bestuivers voor de landbouw en oorzaken voor hun achteruitgang. Alterra Wageningen UR, Wageningen. 
Schouten, M.A., Barendregt, A., Verweij, P.A., Kalkman, V.J., Kleukers, R., Lenders, H.J.R. \& Siebel, H.N. 2010. Defining hotspots of characteristic species for multiple taxonomic groups in the Netherlands. Biodiversity and Conservation 19: 2517-2536.

Smit, J.T. 2016. Analyse karakteristieke soorten van de Nederlandse Delta. EIS Kenniscentrum Insecten, Leiden.

Sommaggio, D. 1999. Syrphidae: can they be used as environmental bioindicators? Agriculture, Ecosystems \& Environment 74: 343-356.

Ssymank, A. 2001. Vegetation und blütenbesuchende Insekten in der Kulturlandschaft : Pflanzengesellschaften, Blühphänologie, Biotopbindung und Raumnutzung von Schwebfliegen (Diptera, Syrphidae) im Drachenfelser Ländchen sowie Methodenoptimierung und Landschaftsbewertung. Bundesamt für Naturschutz, Bonn-Bad Godesberg.

Ter Braak, C.J.F. \& Šmilauer, P. 2012. Canoco reference manual and user's guide: software for ordination, version 5.0 .

Tichy, L. \& Chytry, M. 2006. Statistical determination of diagnostic species for site groups of unequal size. Journal of Vegetation Science 17: 809-818.

Weeda, E.J., Ozinga, W.A. \& Jagers op Akkerhuis, G.A.J.M. 2006. Diversiteit hoog houden: bouwstenen voor een geïntegreerd natuurbeheer. Alterra, Wageningen. 


\section{Bijlage 1 Alfabetisch overzicht bijen en zweefvliegen}

De relatieve voorkeur van bijen (1A) en zweefvliegen (1B) voor verschillende landschapstypen op basis van de 'Phi coefficient of association' ( $\Phi$; hogere waarden met een dieper groene tint). In tegenstelling tot Tabel 3 en 4 staan de soorten in deze bijlage alfabetisch geordend op basis van hun wetenschappelijke naam. Daarnaast worden ook de Nederlandse namen vermeld. Ten behoeve van de leesbaarheid zijn in de tabel alleen cellen met $\Phi \geq 0$ weergegeven. Soorten die opgenomen zijn op de Rode Lijst zijn rood en cursief weergegeven en dominante gewasbestuivers vet met een lichtblauwe achtergrond. Het aantal geselecteerde kilometerhokken waarin de soort is waargenomen, wordt in de een-na-laatste kolom vermeld.

\section{A: Bijen}

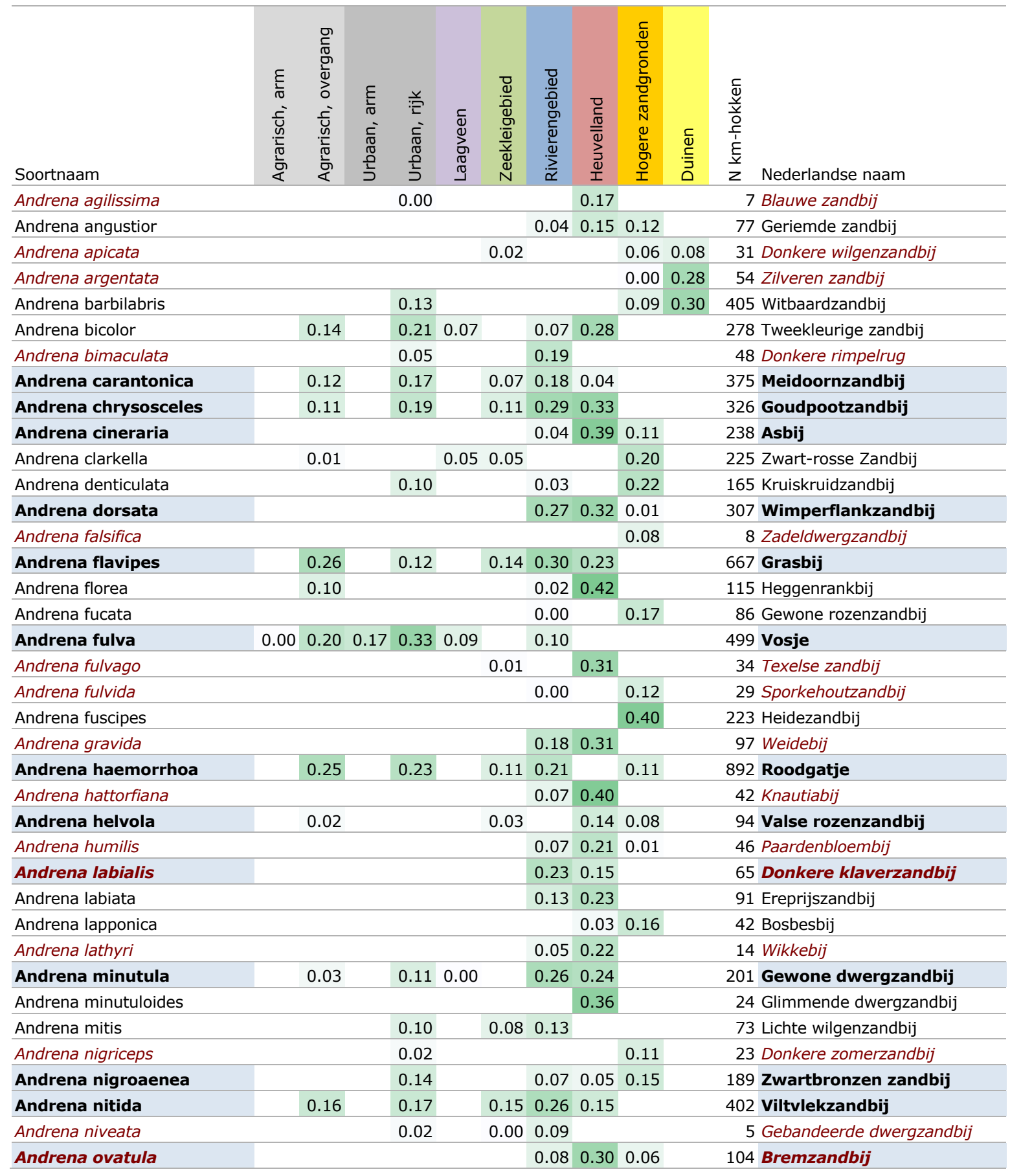




\begin{tabular}{|c|c|c|c|c|c|c|c|c|c|c|c|}
\hline Soortnaam & 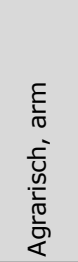 & $\begin{array}{l}0 \\
\frac{0}{0} \\
0 \\
\frac{0}{0} \\
0 \\
0 \\
5 \\
\frac{5}{0} \\
\frac{n}{1} \\
\frac{0}{0} \\
\frac{0}{4}\end{array}$ & 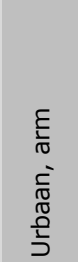 & 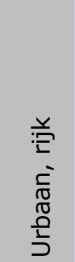 & 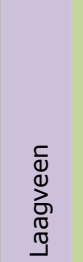 & 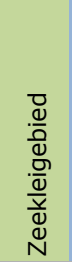 & $\begin{array}{l}\frac{0}{0} \\
\frac{d}{0} \\
\frac{0}{0} \\
\frac{0}{d} \\
\frac{d}{2} \\
\frac{\alpha}{\alpha}\end{array}$ & 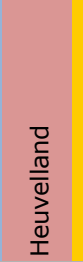 & 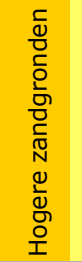 & $\begin{array}{l}\frac{c}{d} \\
\frac{c}{3} \\
0\end{array}$ & 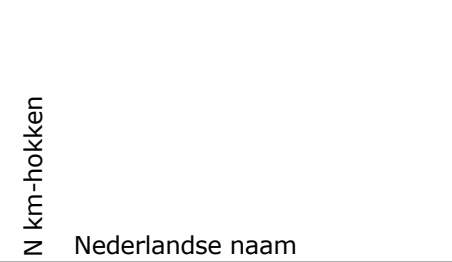 \\
\hline Andrena pandellei & & & & & & & & 0.20 & & & 5 Donkere klokjeszandbij \\
\hline Andrena pilipes & & 0.01 & & 0.10 & & & 0.08 & & 0.00 & & 18 Koolzwarte zandbij \\
\hline Andrena polita & & & & 0.00 & & & & 0.17 & & & 5 Grote glimmende zandbij \\
\hline Andrena praecox & & 0.05 & & 0.08 & & 0.12 & 0.15 & & 0.11 & & 248 Vroege zandbij \\
\hline Andrena proxima & & 0.01 & & 0.02 & & & 0.20 & 0.30 & & & 134 Fluitenkruidbij \\
\hline Andrena rosae & & 0.01 & & & & 0.12 & 0.11 & 0.07 & & & 35 Roodrandzandbij \\
\hline Andrena ruficrus & & & & & & & & 0.01 & 0.18 & & 56 Roodscheenzandbij \\
\hline Andrena semilaevis & & & & 0.03 & & & 0.18 & 0.11 & & & 34 Halfgladde dwergzandbij \\
\hline Andrena strohmella & & & & & & & 0.06 & 0.17 & & & 16 Gekielde dwergzandbij \\
\hline Andrena subopaca & & 0.07 & & 0.09 & & 0.12 & 0.11 & 0.15 & 0.02 & & 330 Witkopdwergzandbij \\
\hline Andrena synadelpha & & & & 0.09 & & & 0.12 & & 0.05 & & 50 Breedrandzandbij \\
\hline Andrena tarsata & & & & & & & & & 0.07 & & 7 Tormentilzandbij \\
\hline Andrena tibialis & & 0.13 & & 0.27 & 0.05 & 0.05 & 0.04 & & & & 158 Grijze rimpelrug \\
\hline Andrena vaga & & & & & & & 0.21 & 0.09 & 0.32 & & 464 Grijze zandbij \\
\hline Andrena varians & & & & 0.00 & & 0.07 & 0.00 & & 0.08 & & 35 Variabele zandbij \\
\hline Andrena ventralis & & 0.01 & & 0.07 & 0.02 & 0.06 & 0.22 & 0.05 & & & 232 Roodbuikje \\
\hline Andrena viridescens & & & & & & & 0.06 & 0.11 & & & 6 Groene zandbij \\
\hline Andrena wilkella & & & & & & & 0.17 & 0.15 & 0.03 & & 102 Geelstaartklaverzandbij \\
\hline Anthidiellum strigatum & & & & & & & 0.02 & 0.14 & 0.22 & & 136 Kleine harsbij \\
\hline Anthidium manicatum & 0.17 & 0.14 & 0.35 & 0.31 & 0.03 & & & 0.07 & & & 267 Grote wolbij \\
\hline Anthidium punctatum & & & & & & & 0.03 & 0.28 & & 0.12 & 58 Kleine wolbij \\
\hline Anthophora furcata & & 0.08 & & 0.16 & & & & 0.19 & & 0.03 & 73 Andoornbij \\
\hline Anthophora plumipes & 0.07 & 0.16 & 0.18 & 0.26 & & 0.02 & 0.06 & 0.20 & & & 262 Gewone sachembij \\
\hline Anthophora quadrimaculata & & 0.05 & & 0.07 & & & & 0.17 & & & 18 Kattenkruidbij \\
\hline Anthophora retusa & & & & & & & & 0.27 & & & 20 Zwarte sachembij \\
\hline Bombus bohemicus & & 0.05 & & & & 0.05 & & 0.05 & 0.07 & 0.10 & 115 Tweekleurige koekoekshommel \\
\hline Bombus campestris & 0.04 & 0.06 & & 0.01 & 0.04 & 0.10 & 0.01 & 0.02 & & & 285 Gewone koekoekshommel \\
\hline Bombus cryptarum & & & & & & 0.06 & & & 0.09 & 0.08 & 41 Wilgenhommel \\
\hline Bombus hortorum & 0.20 & 0.13 & 0.14 & 0.15 & 0.15 & 0.06 & 0.00 & 0.07 & & & 522 Tuinhommel \\
\hline Bombus humilis & & & & 0.00 & & & & & 0.08 & 0.03 & 18 Heidehommel \\
\hline Bombus hypnorum & 0.23 & 0.16 & 0.37 & 0.21 & 0.23 & & & & & & 624 Boomhommel \\
\hline Bombus jonellus & & & & & 0.00 & & 0.01 & & 0.16 & 0.17 & 188 Veenhommel \\
\hline Bombus lapidarius & 0.26 & 0.13 & 0.32 & 0.24 & 0.11 & 0.06 & 0.07 & & & & 1066 Steenhommel \\
\hline Bombus lucorum & 0.11 & 0.02 & & & 0.11 & 0.15 & & & 0.01 & 0.14 & 523 Veldhommel \\
\hline Bombus magnus & & & & & & 0.02 & & & 0.16 & 0.01 & 59 Grote veldhommel \\
\hline Bombus muscorum & & & & & 0.12 & 0.11 & & & & 0.18 & 78 Moshommel \\
\hline Bombus norvegicus & & & & 0.07 & & & & 0.02 & 0.05 & 0.03 & 30 Boomkoekoekshommel \\
\hline Bombus pascuorum & 0.34 & 0.17 & 0.38 & 0.17 & 0.29 & 0.07 & & & & & 1519 Akkerhommel \\
\hline Bombus pratorum & 0.32 & 0.19 & 0.30 & 0.22 & 0.24 & 0.06 & & & & 0.01 & 959 Weidehommel \\
\hline Bombus ruderarius & & 0.01 & & & & 0.15 & & & & 0.13 & 129 Grashommel \\
\hline Bombus rupestris & & & & & & & 0.09 & 0.21 & & & 38 Rode koekoekshommel \\
\hline Bombus soroeensis & & & & & & & & 0.21 & & & 6 Late hommel \\
\hline Bombus sylvestris & & 0.08 & & 0.03 & 0.21 & 0.06 & & 0.02 & 0.01 & 0.00 & 229 Vierkleurige koekoekshommel \\
\hline Bombus terrestris & 0.19 & 0.08 & & 0.05 & 0.08 & 0.19 & & & & 0.10 & 976 Aardhommel \\
\hline Bombus vestalis & & 0.01 & & & & & 0.07 & 0.21 & & & 164 Grote koekoekshommel \\
\hline Bombus veteranus & & & & & & 0.06 & & & & & 13 Zandhommel \\
\hline Ceratina cyanea & & & & & & & & 0.37 & & & 31 Blauwe ertsbij \\
\hline Chalicodoma ericetorum & & 0.11 & & 0.15 & & & 0.11 & 0.16 & & & 121 Lathyrusbij \\
\hline Chelostoma campanularum & & 0.05 & & & & & & 0.34 & & & 57 Kleine klokjesbij \\
\hline Chelostoma florisomne & & 0.00 & & 0.02 & & & 0.17 & 0.20 & 0.06 & & 117 Ranonkelbij \\
\hline Chelostoma rapunculi & 0.00 & 0.14 & 0.04 & 0.25 & & & & 0.28 & & & 153 Grote klokjesbij \\
\hline Coelioxys alata & & & & & & & 0.06 & & 0.00 & 0.04 & 6 Kielstaartkegelbij \\
\hline Coelioxys aurolimbata & & & & 0.03 & & & & 0.17 & & & 9 Gouden kegelbij \\
\hline Coelioxys conoidea & & & & & & & 0.01 & & & 0.11 & 9 Grote kegelbij \\
\hline Coelioxys elongata & & & & 0.06 & & & 0.05 & & & 0.03 & 10 Slanke kegelbij \\
\hline Coelioxys inermis & & 0.01 & & 0.02 & & & 0.11 & 0.03 & & 0.13 & 66 Gewone kegelbij \\
\hline Coelioxys mandibularis & & & & & & & & & & 0.33 & 73 Duinkegelbij \\
\hline Colletes cunicularius & & & & & & & 0.09 & 0.12 & 0.05 & 0.37 & 357 Grote zijdebij \\
\hline
\end{tabular}




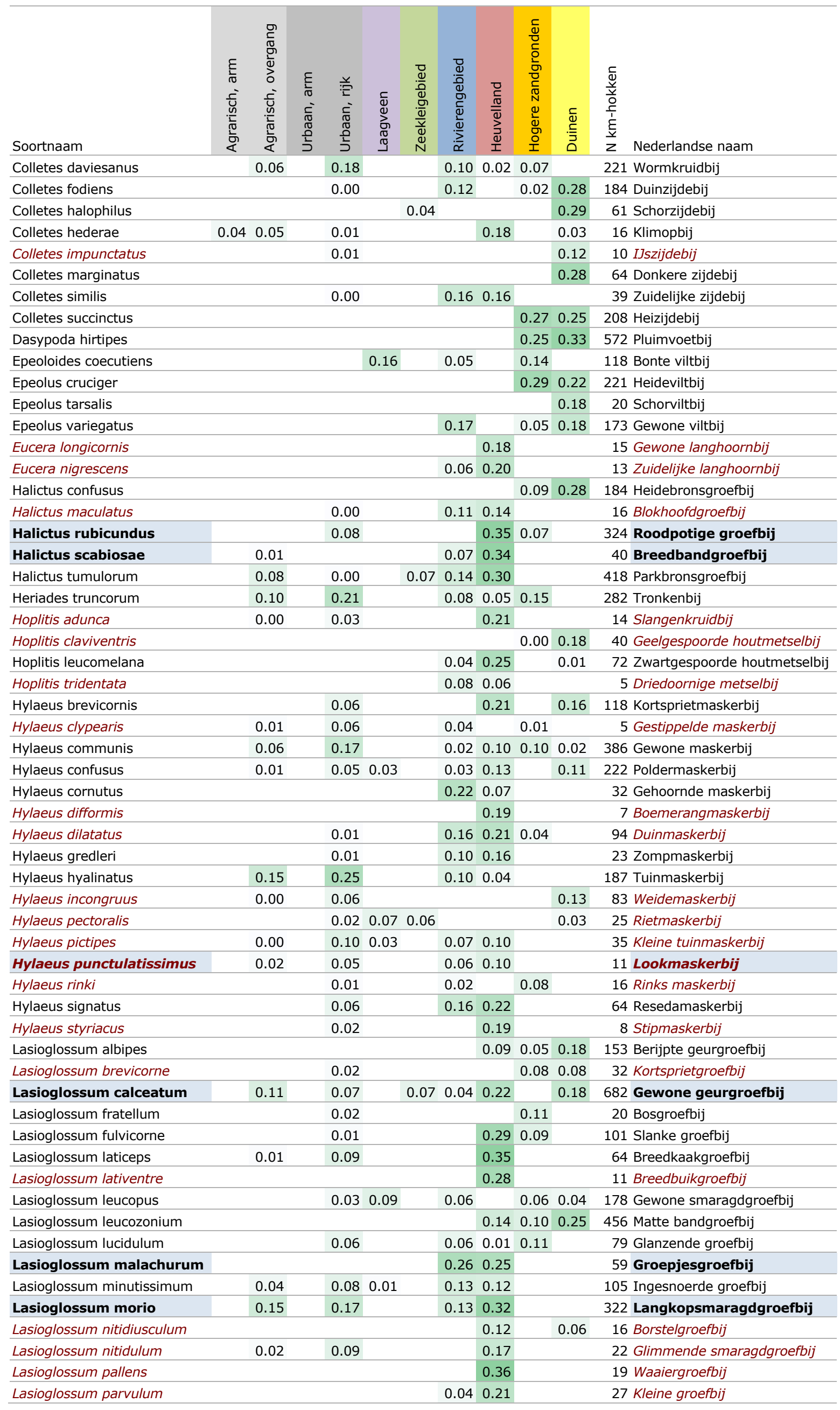


Soortnaam

\section{Lasioglossum pauxillum}

Lasioglossum prasinum

Lasioglossum punctatissimum

Lasioglossum pygmaeum

Lasioglossum quadrinotatulum

Lasioglossum quadrinotatum

Lasioglossum rufitarse

Lasioglossum sabulosum

Lasioglossum semilucens

Lasioglossum sexnotatum

Lasioglossum sexstrigatum

Lasioglossum tarsatum

Lasioglossum villosulum

Lasioglossum xanthopus

Lasioglossum zonulum

Macropis europaea

Macropis fulvipes

Megachile analis

Megachile centuncularis

Megachile circumcincta

Megachile dorsalis

Megachile lapponica

Megachile leachella

Megachile ligniseca

Megachile maritima

Megachile pilidens

Megachile versicolor

Megachile willughbiella

Melecta albifrons

Melitta haemorrhoidalis

Melitta leporina

Melitta nigricans

Melitta tricincta

Nomada alboguttata

Nomada armata

Nomada bifasciata

Nomada conjungens

Nomada distinguenda

Nomada fabriciana

Nomada femoralis

Nomada ferruginata

Nomada flava

Nomada flavoguttata

Nomada flavopicta

Nomada fucata

Nomada fulvicornis

Nomada fuscicornis

Nomada goodeniana

Nomada guttulata

Nomada integra

Nomada lathburiana

Nomada leucophthalma

Nomada marshamella

Nomada obscura

Nomada panzeri

Nomada ruficornis

Nomada rufipes

Nomada sexfasciata

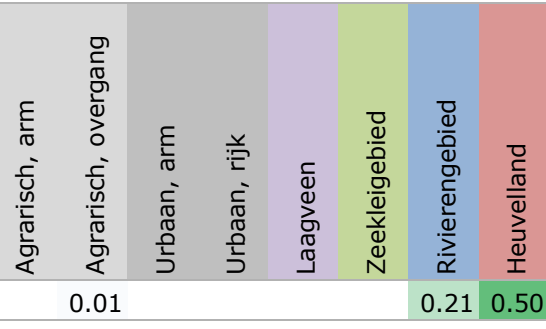

\section{I

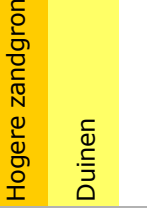

$z$ Nederlandse naam

168 Kleigroefbij

$\begin{array}{lll}0.12 & 0.04 \quad 29 \text { Viltige groefbij }\end{array}$

$\begin{array}{llll}0.18 & 0.06 & 0.22 & 149 \text { Fijngestippelde groefbij }\end{array}$

0.23

8 Dwerggroefbij

0.1070 Steilrandgroefbij

0.20

0.13

0.04

0.06

19 Kleine bandgroefbij

9 Zadelgroefbij

$0.16 \quad 53$ Glanzende franjegroefbij

87 Halfglanzende groefbij

$\begin{array}{llll}0.08 & 0.08 & 0.02\end{array}$

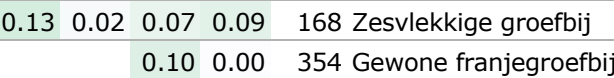

$0.01 \quad 0.12$

0.06

0.1613 Duingroefbij

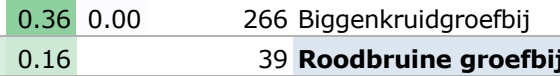

$\begin{array}{lll}0.03 & 0.12 \quad 0.16\end{array}$

\begin{tabular}{|r|r|r|r|r|}
0.02 & 0.04 & 0.15 & 0.05 & 165 Glanzende bandgroefbij \\
\hline 0.11 & 0.16 & 265 Gewone slobkousbij
\end{tabular}

$0.10 \quad 11$ Bruine slobkousbij

$0.050 .03 \quad 6$ Ericabij

\begin{tabular}{|c|c|c|c|c|c|c|}
\hline 0.12 & 0.22 & 0.03 & 0.04 & 0.03 & 0.03 & 262 Tuinbladsnijder \\
\hline & & & 0.01 & 0.00 & 0.24 & 58 Ruige behangersbij \\
\hline
\end{tabular}

$0.10 \quad 5$

0.04

$0.08 \quad 0.04$

31 Lapse behangersbij

0.47121 Zilveren fluitje

0.0256 Distelbehangersbij

0.3255 Kustbehangersbij

0.20

5 Rotsbehangersbij

$\begin{array}{lllll}0.05 & 0.13 & 0.02 & 0.14 \quad 137 \text { Gewone behangersbij }\end{array}$

$0.02 \quad 0.06 \quad 366$ Grote bladsnijder

$0.07 \quad 0.19 \quad 55$ Bruine rouwbij

$0.140 .02 \quad 95$ Klokjesdikpoot

77 Klaverdikpoot

\begin{tabular}{l|l|r|r|}
0.28 & 0.02 & 0.02 & 115 Kattenstaartdikpoot \\
0.21 & 0.13 & & 32 Ogentroostdikpoot \\
\hline 0.18 & & 0.17 & 249 Bleekvlekwespbij
\end{tabular}

\begin{tabular}{r|r|r|r}
0.28 & 0.02 & 0.02 & 115 Kattenstaartdikpoot \\
0.21 & 0.13 & 32 Ogentroostdikpoot \\
\hline 0.18 & & 0.17 & 249 Bleekvlekwespbij
\end{tabular}

0.18

$\begin{array}{lll}0.05 & 0.19 & 16 \text { Knautiawespbij } \\ 0.16 & 0.23 & 45 \text { Bonte wespbij }\end{array}$

$\begin{array}{ll}0.16 & 0.23\end{array}$

41 Langsprietwespbij

6 Langsprietdwergwespbij

0.17

231 Roodzwarte dubbeltand

$\begin{array}{lllll}0.02 & 0.00 & 0.05 & 0.27 & 0.26\end{array}$

17 Dubbeldoornwespbij

$\begin{array}{lll}0.10 & 0.28\end{array}$

$\begin{array}{lll}0.00 & 0.16 & 0.01\end{array}$

137 Geelschouderwespbij

399 Gewone wespbij

252 Gewone kleine wespbij

91 Zwartsprietwespbij

283 Kortsprietwespbij

79 Roodsprietwespbij

31 Bruinsprietwespbij

205 Smalbandwespbij

6 Gedrongen wespbij

11 Tweekleurige wespbij

292 Roodharige wespbij

107 Vroege wespbij

197 Donkere wespbij

13 Donkere dubbeltand

160 Sierlijke wespbij

355 Gewone dubbeltand

$\begin{array}{llllll}0.10 & 0.01 & 0.07 & 0.17 & 0.05\end{array}$

$\begin{array}{lllll}0.08 & 0.26 & 0.23 & 0.07\end{array}$

213 Heidewespbij

6 Grote wespbij 


\begin{tabular}{|c|c|c|c|c|c|c|c|c|c|c|c|}
\hline Soortnaam & $\begin{array}{l}\frac{E}{1} \\
\frac{1}{0} \\
\frac{5}{U} \\
\frac{n}{1} \\
\frac{0}{0} \\
\frac{0}{4}\end{array}$ & $\begin{array}{l}\text { O } \\
\frac{1}{0} \\
0 \\
\frac{1}{0} \\
0 \\
0 \\
\frac{5}{U} \\
\frac{5}{2} \\
\frac{10}{0} \\
\frac{0}{4}\end{array}$ & $\begin{array}{l}\frac{E}{10} \\
\frac{1}{0} \\
\frac{5}{0} \\
\mathbb{0} \\
\frac{0}{2} \\
\end{array}$ & 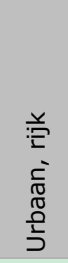 & 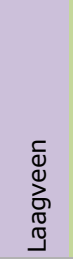 & $\begin{array}{l}\frac{D}{d} \\
\frac{d}{0} \\
0 \\
\frac{0}{0} \\
\frac{v}{d} \\
N\end{array}$ & 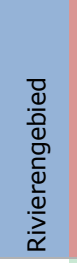 & 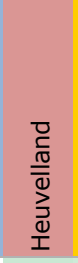 & 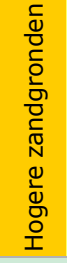 & $\begin{array}{l}\frac{c}{d} \\
\frac{c}{3} \\
0\end{array}$ & Nederlandse naam \\
\hline Nomada signata & & & & 0.09 & & & 0.02 & 0.20 & 0.06 & & 146 Signaalwespbij \\
\hline Nomada similis & & & & & & & 0.07 & & 0.10 & & 21 Matglanswespbij \\
\hline Nomada stigma & & & & & & & 0.14 & 0.11 & & & 18 Borstelwespbij \\
\hline Nomada striata & & & & & & & 0.05 & 0.18 & 0.05 & & 40 Stomptandwespbij \\
\hline Osmia bicornis & 0.16 & 0.25 & 0.32 & 0.42 & & & 0.00 & & & & 602 Rosse metselbij \\
\hline Osmia caerulescens & & 0.12 & & 0.17 & & 0.01 & & 0.07 & & & 87 Blauwe metselbij \\
\hline Osmia cornuta & & 0.08 & 0.03 & 0.21 & & & 0.04 & 0.08 & & & 119 Gehoornde metselbij \\
\hline Osmia leaiana & & & & 0.00 & & & & 0.15 & & & 17 Kauwende metselbij \\
\hline Osmia niveata & & 0.03 & & 0.04 & & & 0.12 & 0.17 & & & 36 Zwartbronzen houtmetselbij \\
\hline Osmia spinulosa & & & & & & & & 0.02 & & 0.17 & 19 Gedoornde slakkenhuisbij \\
\hline Osmia uncinata & & & & & & & & & 0.14 & 0.01 & 32 Bosmetselbij \\
\hline Panurgus banksianus & & & & & & 0.01 & & & 0.22 & & 97 Grote roetbij \\
\hline Panurgus calcaratus & & & & & & & 0.00 & 0.07 & 0.30 & & 209 Kleine roetbij \\
\hline Sphecodes hyalinatus & & & & & & & & 0.21 & & & 10 Lichte bloedbij \\
\hline Sphecodes longulus & & & & 0.03 & & & 0.03 & 0.15 & 0.03 & 0.06 & 85 Kleine spitstandbloedbij \\
\hline Sphecodes majalis & & & & & & & & 0.28 & & & 10 Kortsnuitbloedbij \\
\hline Sphecodes marginatus & & & & 0.01 & & & 0.15 & 0.01 & 0.06 & & 69 Verscholen dwergbloedbij \\
\hline Sphecodes miniatus & & & & 0.06 & & & 0.09 & 0.09 & 0.03 & & 183 Gewone dwergbloedbij \\
\hline Sphecodes monilicornis & & & & & & & 0.15 & 0.20 & 0.00 & & 302 Dikkopbloedbij \\
\hline Sphecodes niger & & & & & & & & 0.23 & & & 11 Zwarte bloedbij \\
\hline Sphecodes pellucidus & & & & & & & 0.09 & & 0.21 & 0.17 & 245 Schoffelbloedbij \\
\hline Sphecodes puncticeps & & & & & & & & 0.08 & 0.03 & 0.04 & 88 Grote spitstandbloedbij \\
\hline Sphecodes reticulatus & & & & 0.00 & & & & & 0.14 & 0.10 & 115 Rimpelkruinbloedbij \\
\hline Sphecodes rubicundus & & & & & & & 0.10 & 0.21 & & & 58 Vroege bloedbij \\
\hline Sphecodes scabricollis & & & & & & 0.00 & & & 0.07 & 0.06 & 24 Wafelbloedbij \\
\hline Stelis breviuscula & & 0.02 & 0.00 & 0.10 & 0.06 & & & & 0.07 & & 43 Gewone tubebij \\
\hline Stelis minuta & & 0.02 & & 0.07 & & & 0.01 & 0.07 & & & 6 Minitubebij \\
\hline Stelis ornatula & & 0.01 & & & & & 0.00 & 0.15 & & 0.02 & 14 Witgevlekte tubebij \\
\hline Stelis phaeoptera & & 0.01 & & 0.01 & & & 0.07 & 0.06 & & & 7 Zwarte tubebij \\
\hline Stelis punctulatissima & 0.03 & 0.12 & & 0.17 & & 0.00 & 0.00 & 0.05 & & & 81 Geelgerande tubebij \\
\hline Stelis signata & & & & & & & & & 0.07 & & 8 Gele tubebij \\
\hline Xylocopa violacea & 0.05 & 0.01 & 0.10 & 0.06 & & 0.02 & 0.01 & & & & 11 Blauwzwarte houtbij \\
\hline
\end{tabular}




\section{B: Zweefvliegen}

Soortnaam

Anasimyia contracta

Anasimyia interpuncta

Anasimyia lineata

Anasimyia transfuga

Baccha elongata

Brachyopa bicolor

Brachyopa insensilis

Brachyopa pilosa

Brachyopa scutellaris

Brachyopa testacea

Brachypalpoides lentus

Brachypalpus laphriformis

Caliprobola speciosa

Callicera fagesii

Callicera rufa

Ceriana conopsoides

Chalcosyrphus nemorum

Chalcosyrphus piger

Chamaesyrphus lusitanicus

Cheilosia albipila

Cheilosia albitarsis / ranunculi

Cheilosia barbata

Cheilosia bergenstammi

Cheilosia caerulescens

Cheilosia canicularis/himantopus

Cheilosia carbonaria

Cheilosia chrysocoma

Cheilosia cynocephala

Cheilosia fasciata

Cheilosia fraterna

Cheilosia grossa

Cheilosia illustrata

Cheilosia impressa

Cheilosia latifrons

Cheilosia lenis

Cheilosia longula

Cheilosia mutabilis

Cheilosia pagana

Cheilosia proxima

Cheilosia psilophthalma

Cheilosia scutellata

Cheilosia semifasciata

Cheilosia urbana

Cheilosia uviformis

Cheilosia variabilis

Cheilosia velutina

Cheilosia vernalis

Chrysogaster cemiteriorum

Chrysogaster solstitialis

Chrysogaster viduata

Chrysogaster virescens

Chrysotoxum arcuatum

Chrysotoxum bicinctum

Chrysotoxum cautum

Chrysotoxum festivum

Chrysotoxum octomaculatum

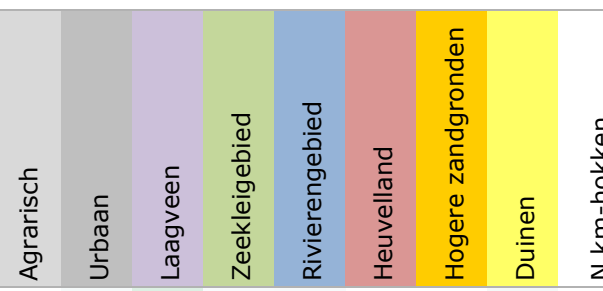

$\begin{array}{lllll}0.01 & 0.07 & 0.01 & 0.01\end{array}$

$\begin{array}{llll}0.17 & 0.06 & 0.14\end{array}$

\begin{tabular}{ll|l|l|l|l}
0.00 & 0.34 & 0.01 & 0.04
\end{tabular}

$\begin{array}{lllll}0.01 & 0.06 & 0.07 & 0.07\end{array}$

0.02

0.00

0.01

0.22

0.110 .00

$0.06 \quad 0.01$

0.01

$z$ Nederlandse naam

28 Ingesnoerde waterzweefvlieg

150 Bokserwaterzweefvlieg

336 Snuitwaterzweefvlieg

77 Rechte waterzweefvlieg

0.09386 Vliegende speld

23 Gedeukte sapzweefvlieg

6 Kale sapzweefvlieg

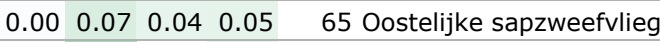

$\begin{array}{llll}0.01 & 0.19 & 0.05 & 59\end{array}$

\begin{tabular}{ll|lll}
0.01 & 0.07 & 17 Dennensapzweefvlieg
\end{tabular}

\begin{tabular}{l|l|l|l|l}
0.03 & 0.14 & 0.05 & 0.01 & 148 Bloedrode bladloper
\end{tabular}

$\begin{array}{llllll}0.00 & 0.10 & 0.08 & 54 \text { Gevlekte molmzweefvlieg }\end{array}$

0.11

5 Juweelzweefvlieg

5 Donkere glanszweefvlieg

$0.04 \quad 8$ Dennenglanszweefvlieg

\begin{tabular}{|l|llllll}
0.01 & & 0.01 & 0.02 & 0.08 & & 37 Normale fopblaaskop \\
\hline 0.08 & & 0.07 & 0.01 & 0.05 & 0.01 & 237 Korte bladloper
\end{tabular}

$0.090 .04 \quad 33$ Roodpuntbladloper

$0.03 \quad 0.05 \quad 7$ Duinheidedwerg

$\begin{array}{llllllll}0.00 & 0.04 & 0.01 & 0.07 & 0.03 & 0.01 & 207 & \text { Tweekleurig gitje }\end{array}$

$\begin{array}{lllll}0.05 & 0.13 & 0.06 & 0.03 & 556 \text { Gewoon / zuidelijk weidegitje }\end{array}$

$0.18 \quad 7$ Ongeschoren gitje

$\begin{array}{lllll}0.00 & 0.00 & 0.09 & 0.14 & 227 \text { Kruiskruidgitje }\end{array}$

$0.14 \quad 0.03 \quad 57$ Tuingitje

$0.24 \quad 2$ Laat / vroeg hoefbladgitje

$\begin{array}{llll}0.05 & 0.02 & 0.01 & 14\end{array}$ Trapeziumgitje

$0.090 .12 \quad 41$ Vosrood gitje

$\begin{array}{llll}0.05 & 0.04 & 0.09 & 39 \text { Blauw gitje }\end{array}$

6 Vroegste gitje

$\begin{array}{llll}0.04 & 0.03 & 0.03 & 70 \text { Moerasgitje }\end{array}$

$0.02 \quad 0.00$

$\begin{array}{llll}0.04 & 0.03 & 0.03 \quad 70 \text { Moerasgitje }\end{array}$

$\begin{array}{llll}0.06 & 0.10 & 0.05 \quad 100 \text { Wilgengitje }\end{array}$

$\begin{array}{llll}0.00 & 0.08 & 0.09 & 0.32\end{array}$

621 Wollig gitje

$0.03 \quad 0.14$

0.14

0.11146 Nazomergitje

$0.01 \quad 19$ Bruin gitje

0.21

10 Limburgs bosgitje

0.069 Heidegitje

$\begin{array}{llll}0.00 & 0.00 & 0.10 \quad 11 \text { Slank gitje }\end{array}$

799 Kervelgitje

114 Dofbuikgitje

\begin{tabular}{|l|l|l|l|l|l|l|l|l|l|l}
0.00 & 0.02 & 0.13 & 0.06 & 0.27 & & 799 Kervelgitje \\
\hline 0.00 & 0.06 & 0.29 & & 114 Dofbuikgitje
\end{tabular}

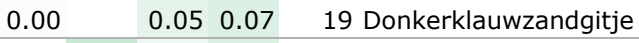

$\begin{array}{llll}0.11 & 0.03 & 0.07 & 72 \text { Paddenstoelgitje }\end{array}$

$\begin{array}{lllllll}0.11 & 0.01 & 0.02 & 0.01 & 0.00 & 93 & \text { Vetplantgitje }\end{array}$

$\begin{array}{llllll}0.01 & 0.00 & 0.08 & 0.05 & 49 & \text { Lichtklauwzandgitje }\end{array}$

0.030 .01

0.046 Zilverkopgitje

$\begin{array}{lllll}0.00 & 0.25 & 0.06 & 0.02 \quad 208 \text { Bosgitje }\end{array}$

$\begin{array}{llll}0.04 & 0.05 & 0.00 & 11 \text { Fluwelen gitje }\end{array}$

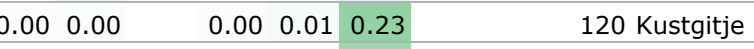

$0.20 \quad 9$ Geelvleugeldoflijfje

$0.27 \quad 0.02 \quad 211$ Donker doflijfje

$\begin{array}{lllllll}0.08 & 0.02 & 0.14 & 77 \text { Kaal doflijfje }\end{array}$

$\begin{array}{lll}0.03 & 0.07 & 19 \text { Groen doflijfje }\end{array}$

$\begin{array}{llll}0.03 & 0.03 & 0.02 \quad 20 & \text { Bolle fopwesp }\end{array}$

$\begin{array}{llll}0.22 & 0.11 & 0.01 & 262 \\ & \text { Donkere fopwesp }\end{array}$

0.00

$\begin{array}{llll}0.09 & 0.07 & 0.20\end{array}$

412 Grote fopwesp

$\begin{array}{lllll}0.01 & 0.00 & 0.07 & 0.06 & 85 \text { Stipfopwesp }\end{array}$

$0.01 \quad 0.05 \quad 8$ Heidefopwesp 
Soortnaam

Chrysotoxum vernale

Chrysotoxum verralli

Criorhina asilica

Criorhina berberina

Criorhina floccosa

Criorhina pachymera

Criorhina ranunculi

Dasysyrphus albostriatus

Dasysyrphus hilaris

Dasysyrphus pauxillus

Dasysyrphus pinastri

Dasysyrphus tricinctus

Dasysyrphus venustus

Didea alneti

Didea fasciata

Didea intermedia

Epistrophe diaphana

Epistrophe eligans

Epistrophe flava

Epistrophe grossulariae

Epistrophe melanostoma

Epistrophe nitidicollis

Epistrophella euchroma

Episyrphus balteatus

Eristalinus aeneus

Eristalinus sepulchralis

Eristalis abusiva

Eristalis anthophorina

Eristalis arbustorum

Eristalis horticola

Eristalis intricaria

Eristalis nemorum

Eristalis pertinax

Eristalis picea

Eristalis similis

Eristalis tenax

Eumerus funeralis

Eumerus ornatus

Eumerus strigatus

Eumerus tricolor

Eupeodes corollae

Eupeodes lapponicus

Eupeodes latifasciatus

Eupeodes luniger

Eupeodes nielseni

Ferdinandea cuprea

Helophilus hybridus

Helophilus pendulus

Helophilus trivittatus

Heringia brevidens

Heringia heringi

Heringia latitarsis

Heringia pubescens

Heringia vitripennis

Lejogaster metallina

Lejogaster tarsata

Lejops vittata

Leucozona laternaria

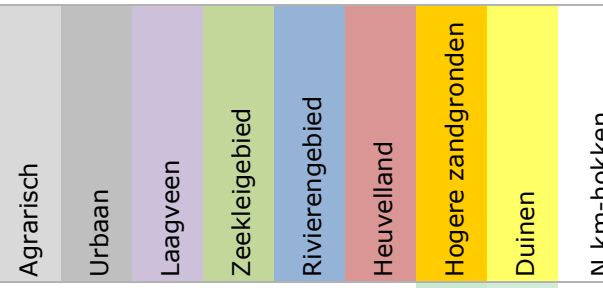

$\begin{array}{ll}0.11 & 0.09\end{array}$

$z$ Nederlandse naam

66 Streepfopwesp

8 Saksische fopwesp

23 Bij-woudzwever

0.22

$\begin{array}{llll}0.02 & 0.20 & 0.01 & 0.06\end{array}$

0.22

$0.18 \quad 0.00$

36 Kleine woudzweve

49 Pluimwoudzwever

0.26

32 Populierenwoudzwever

24 Hommelwoudzwever

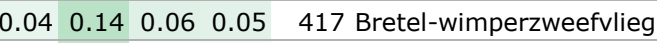

$\begin{array}{lllll}0.12 & 0.00 & 0.01 & 15 & \text { Geelsnoet-wimperzweefvlieg }\end{array}$

$0.05 \quad 8$ Donkere wimperzweefvlieg

$\begin{array}{llll}0.08 & 0.02 & 0.02 & 16\end{array}$ Zwartsprietwimperzweefvlieg

$\begin{array}{llll}0.08 & 0.12 & 0.02 & 264 \text { Geelbandwimperzweefvlieg }\end{array}$

0.00

0.00

$\begin{array}{lll}0.02 & 0.12 \quad 0.11\end{array}$

258 Gewone wimperzweefvlieg

$\begin{array}{llllll}0.02 & 0.02 & 0.08 & 32 \text { Groene didea }\end{array}$

$\begin{array}{lllll}0.07 & 0.02 & 0.09 & 0.06 & 185 \\ 0.03 & \text { Bosdidea }\end{array}$

$0.03 \quad 0.090 .07 \quad 63$ Dennendidea

$\begin{array}{llllll} & & 0.11 & & 5 \text { Zuidelijke bandzweefvlieg } \\ 0.12 & 0.00 & 0.14 & 0.02 & 0.04 & 599 \text { Enkele-bandzweefvlieg }\end{array}$

$\begin{array}{lllll}0.00 & 0.05 & 0.03 & 8 \text { Brede bandzweefvlieg }\end{array}$

$\begin{array}{lllll}0.00 & 0.15 & 0.10 & 89 \text { Zwartspriet-bandzweefvlieg }\end{array}$

$\begin{array}{llllll}0.05 & 0.08 & 0.04 & 0.02 & 114 & \text { Zwartbek-bandzweefvlieg }\end{array}$

0.00

$\begin{array}{llllll}0.03 & 0.10 & 0.07 & 0.00 & 235 & \text { Zwarthaar-bandzweefvlieg }\end{array}$

$\begin{array}{llll}0.11 & 0.02 & 13 \text { Stippelelfje }\end{array}$

\section{$\begin{array}{llllll}0.24 & 0.10 & 0.07 & 0.16 & 0.06 & 2325 \text { Snorzweefvlieg }\end{array}$}

$0.06 \quad 0.19 \quad 73$ Kustvlekoog

$\begin{array}{lllllll}0.02 & 0.00 & 0.16 & 0.25 & 0.06 & 0.03 & 885 \text { Weidevlekoog }\end{array}$

$\begin{array}{lllll}0.20 & 0.12 & 0.04 & 0.05 & 283 \text { Kustbijvlieg }\end{array}$

$\begin{array}{llll}0.02 & 0.08 & 0.00 & 8 \text { Friese bijvlieg }\end{array}$

$\begin{array}{llllll}0.05 & 0.00 & 0.15 & 0.07 & 0.14 & 1180 \text { Kleine bijvlieg }\end{array}$

$\begin{array}{lllllll}0.00 & 0.29 & 0.09 & 0.01 & 0.00 & 1130 \text { Bosbijvlieg }\end{array}$

\section{$\begin{array}{lllllllll}0.02 & 0.25 & 0.10 & 0.03 & & 0.01 & 0.07 & 1259 & \text { Hommelbijvlieg }\end{array}$}

$\begin{array}{lllllllll}0.00 & 0.12 & 0.02 & 0.07 & 0.18 & 0.03 & & 1268 \text { Puntbijvlieg }\end{array}$

$\begin{array}{lllllllll}0.00 & 0.00 & 0.01 & 0.09 & 0.10 & 0.03 & 0.03 & 1947 \text { Kegelbijvlieg }\end{array}$

$\begin{array}{llll}0.12 & 0.06 & 0.03 & 44 \text { Veenbijvlieg }\end{array}$

$\begin{array}{lllllll}0.02 & 0.02 & 0.00 & 0.05 & 0.00 & 85 & \text { Onvoorspelbare bijvlieg }\end{array}$

\begin{tabular}{ll|l|l|l|l|l|l|l}
0.24 & 0.15 & 0.08 & 0.01 & 0.08 & 0.11 & 2324 & Blinde bij
\end{tabular}

$\begin{array}{lllll}0.11 & 0.00 & 0.06 & 92 \text { Knobbelbollenzweefvlieg }\end{array}$

$0.16 \quad 9$ Grootoog-bollenzweefvlieg

76 Gewone bollenzweefvlieg

\begin{tabular}{l|c|c|c|}
0.18 & & 7 Kalkbollenzweefvlieg \\
0.05 & 0.11 & 1026 & Terrasjeskommazweefvlieg
\end{tabular}

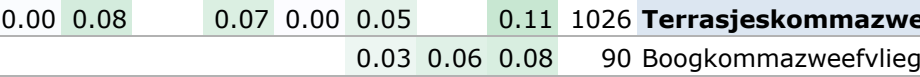

$\begin{array}{lllllll}0.00 & 0.00 & 0.04 & 0.08 & 0.07 & 262 \text { Gele kommazweefvlieg }\end{array}$

$\begin{array}{lllllll}0.00 & 0.11 & 0.03 & 0.18 & 0.04 & 520 \text { Grote kommazweefvlieg }\end{array}$

$\begin{array}{lllll}0.01 & 0.04 & 0.04 & 12 \text { Donkere kommazweefvlieg }\end{array}$

$\begin{array}{lllll}0.00 & 0.17 & 0.17 & 222 \text { Gewone kopermantel }\end{array}$

\begin{tabular}{l|l|l|lll}
0.00 & 0.21 & 0.05 & 420 Moeraspendelvlieg
\end{tabular}

$\begin{array}{llllllllll}0.00 & 0.03 & 0.11 & 0.19 & 0.02 & 0.05 & 0.02 & 2187 & \text { Gewone pendelvlieg }\end{array}$

$\begin{array}{llllllllll}0.00 & 0.00 & 0.09 & 0.14 & 0.03 & 0.01 & 0.15 & 1646 & \text { Citroenpendelvlieg }\end{array}$

$\begin{array}{lllllll}0.00 & 0.00 & 0.08 & 7 \text { Wratjesplatbek }\end{array}$

$\begin{array}{llllllll}0.04 & 0.00 & 0.01 & 0.00 & 0.02 & 19 & \text { Glimmende platbek }\end{array}$

$\begin{array}{llllll}0.00 & 0.01 & 0.04 & 0.02 & 10 & \text { Bokspootplatbek }\end{array}$

$0.120 .03 \quad 24$ Donkerhaarplatbek

$\begin{array}{llllll}0.19 & 0.00 & 0.04 & 0.10 & 43 \text { Gespoorde platbek }\end{array}$

194 Gewoon glimlijfje

$\begin{array}{lll}0.17 & 0.11 & 0.05\end{array}$

64 Moerasglimlijfje

0.107 Heenzweefvlieg

6 Donkere melkzweefvlieg


Soortnaam

Leucozona lucorum / inopinata

Mallota fuciformis

Megasyrphus erratica

Melangyna cincta

Melangyna lasiophthalma

Melangyna quadrimaculata

Melangyna umbellatarum

Melanogaster hirtella

\section{Melanostoma mellinum}

Melanostoma scalare

Meligramma guttata

Meligramma triangulifera

Meliscaeva auricollis

Meliscaeva cinctella

Merodon equestris

Microdon devius

Microdon myrmicae

\section{Myathropa florea}

Myolepta dubia

Neoascia geniculata

Neoascia interrupta

Neoascia meticulosa

Neoascia obliqua

Neoascia podagrica

Neoascia tenur

Olbiosyrphus laetus

Orthonevra brevicornis

Orthonevra geniculata

Orthonevra intermedia

Orthonevra nobilis

Paragus haemorrhous

Paragus pecchiolii

Parasyrphus annulatus

Parasyrphus lineolus

Parasyrphus malinellus

Parasyrphus punctulatus

Parasyrphus vittiger

Parhelophilus consimilis

Parhelophilus frutetorum

Parhelophilus versicolor

Pelecocera tricincta

Pipiza austriaca

Pipiza bimaculata

Pipiza fenestrata

Pipiza lugubris

Pipiza luteitarsis

Pipiza noctiluca

Pipizella annulata

Pipizella viduata

Platycheirus albimanus

Platycheirus ambiguus

Platycheirus angustatus

Platycheirus clypeatus

Platycheirus discimanus

Platycheirus europaeus

Platycheirus fulviventris

Platycheirus immarginatus

Platycheirus manicatus

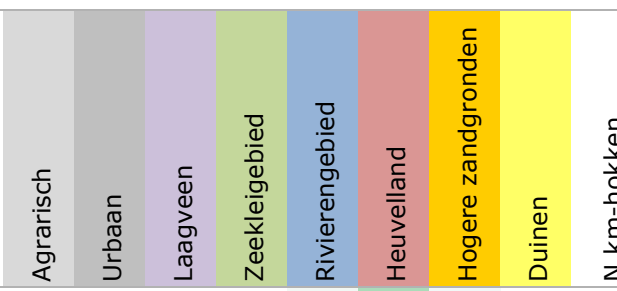

$\begin{array}{lll}0.02 & 0.18 & 0.02\end{array}$

$\begin{array}{lll}0.06 & 0.02\end{array}$

$0.03 \quad 0.10$

$\begin{array}{lll}0.17 & 0.08\end{array}$

0.04

$\begin{array}{llll}0.02 & 0.06 & 0.07\end{array}$

0.08

$\begin{array}{lllll}0.00 & 0.00 & 0.04 & 0.00\end{array}$

0.08

18 Donker elfje

$\begin{array}{lllllll}0.00 & 0.14 & 0.09 & 0.11 & 0.02 & 429 \text { Weidedoflijfje }\end{array}$

$\begin{array}{lllllllll}0.15 & 0.00 & 0.03 & 0.07 & 0.07 & 0.15 & 0.01 & 1282 & \text { Gewone driehoekzweefvlieg }\end{array}$ $\begin{array}{lllllll}0.06 & 0.04 & 0.02 & 0.09 & 0.04 & 0.10 & 1014\end{array}$ Slanke driehoekzweefvlieg

$\begin{array}{llllll}0.04 & 0.04 & 0.02 & 0.07 & 37 \text { Spiegelelfje }\end{array}$ $\begin{array}{lllll}0.06 & 0.04 & 0.07 & 62 \text { Driehoekselfje }\end{array}$

$\begin{array}{lllll}0.09 & 0.10 & 0.15 & 396 \text { Variabel elfje }\end{array}$

$\begin{array}{llll}0.17 & 0.07 & 0.01 & 131 \text { Stomp elfje }\end{array}$

0.22 0.03556 Grote narcisvlieg

$0.21 \quad 13$ Kalkknikspriet

0.046 Moerasknikspriet

\begin{tabular}{ll|l|l|l}
0.07 & 0.01 & 0.22 & 0.12 & 1742 Doodskopzweefvlieg
\end{tabular}

$\begin{array}{llll}0.11 & 0.03 & 18 \text { Gele myolepta }\end{array}$

$\begin{array}{llllll}0.02 & 0.02 & 0.05 & & 9 \text { Kortspriet-korsetzweefvlieg } \\ & 0.02 & 0.03 & 0.05 & 0.05 & 21 \text { Veelvlek-korsetzweefvlieg }\end{array}$

$\begin{array}{lllll}0.18 & 0.04 & 0.05 & 90 \text { Donkere korsetzweefvlieg }\end{array}$

$\begin{array}{llll}0.04 & 0.04 & 0.08\end{array}$

44 Scheefvlek-korsetzweefvlieg

390 Gewone korsetzweefvlieg

196 Tengere korsetzweefvlieg

$\begin{array}{llll}0.28 & 0.04 & 0.03\end{array}$

7 Wimpercitroenzweefvlieg

16 Bosglimmer

12 Vroege glimmer

0.13

0.110 .0

31 Veenglimmer

9 Zomerse glimmer

0.16

$\begin{array}{rrrr}0.12 & 0.12 & 0.11 & 235 \text { Gewoon krieltje } \\ 0.05 & 8 \text { Zilveren krieltje }\end{array}$

$\begin{array}{llll}0.07 & 0.10 & 40 \text { Dennenroetneusje }\end{array}$

$\begin{array}{llll}0.07 & 0.01 & 23 & \text { Zwartpootroetneusje }\end{array}$

$\begin{array}{llll}0.08 & 0.01 \quad 23 \text { Glimmend roetneusje }\end{array}$

$\begin{array}{llllll}0.01 & 0.03 & 0.05 & 0.16 & 248 \text { Gevlekt roetneusje }\end{array}$

$\begin{array}{lll}0.03 & 0.03 \quad 6 \text { Ringpootroetneusje }\end{array}$

0.20

0.13

$0.07 \quad 0.01$

14 Veenfluweelzweefvlieg

$\begin{array}{llll}0.00 & 0.16 & 0.08 & 0.02\end{array}$

107 Bosfluweelzweefvlieg

163 Gewone fluweelzweefvlieg

$\begin{array}{lll}0.10 & 0.10 \quad 55 \text { Bijlsprietje }\end{array}$

$0.16 \quad 8$ Knobbeldijplatbek

$\begin{array}{lll}0.18 & 0.00 \quad 99 & \text { Fijngestippelde platbek }\end{array}$

$\begin{array}{lllll}0.01 & 0.05 & 0.01 & 6 \text { Vliegerplatbek }\end{array}$

$\begin{array}{llll}0.00 & 0.10 & 0.03 \quad 25 \text { Donkere platbek }\end{array}$

$0.00 \quad 0.050 .08 \quad 13$ Slanke platbek

$\begin{array}{llll}0.05 & 0.13 & 0.04 \quad 145 \text { Grofgestippelde platbek }\end{array}$

0.26

$\begin{array}{lll}0.07 & 0.32\end{array}$

$0.04 \quad 0.31$

15 Grote langsprietplatbek

$\begin{array}{llll}0.05 & 0.04 & 7 \text { Krulhaarplatvoetje }\end{array}$

0.07935 Micaplatvoetje

$\begin{array}{lllllll}0.08 & 0.01 & 0.04 & 0.04 & 0.01 & 183 & \text { Slank platvoetje }\end{array}$

$\begin{array}{lllllllll}0.00 & 0.14 & 0.02 & 0.09 & 0.07 & 0.02 & 505 \text { Gewoon platvoetje }\end{array}$

$0.04 \quad 5$ Wilgenplatvoetje

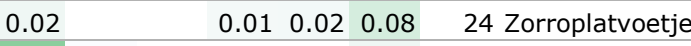

$\begin{array}{llll}0.25 & 0.00 & 0.03 \quad 99 \text { Geel platvoetje }\end{array}$

$\begin{array}{lll}0.00 & 0.09 & 6 \text { Kustplatvoetje }\end{array}$

$\begin{array}{llll}0.04 & 0.05 & 0.08 & 56 \text { Snuitplatvoetje }\end{array}$ 
Soortnaam

Platycheirus occultus

Platycheirus peltatus

Platycheirus perpallidus

Platycheirus scambus

Platycheirus scutatus s.l.

Portevinia maculata

Psilota anthracina

Psilota atra

Pyrophaena granditarsa

Pyrophaena rosarum

Rhingia campestris

Scaeva pyrastri

Scaeva selenitica

Sericomyia lappona

Sericomyia silentis

Sphaerophoria batava

Sphaerophoria fatarum

Sphaerophoria interrupta

Sphaerophoria philanthus

Sphaerophoria rueppelli

Sphaerophoria scripta

Sphaerophoria taeniata

Sphaerophoria virgata

Sphegina clunipes

Sphegina elegans

Sphegina sibirica

Sphegina verecunda

Syritta pipiens

Syrphus nitidifrons

Syrphus ribesii

Syrphus torvus

Syrphus vitripennis

Temnostoma bombylans

Temnostoma vespiforme

Trichopsomyia flavitarsis

Trichopsomyia lucida

Triglyphus primus

Tropidia scita

Volucella bombylans

Volucella inflata

Volucella pellucens

Volucella zonaria

Xanthandrus comtus

Xanthogramma citrofasciatum

Xanthogramma pedissequum

Xanthogramma stackelbergi

Xylota abiens

Xylota segnis

Xylota sylvarum

Xylota tarda

Xylota xanthocnema

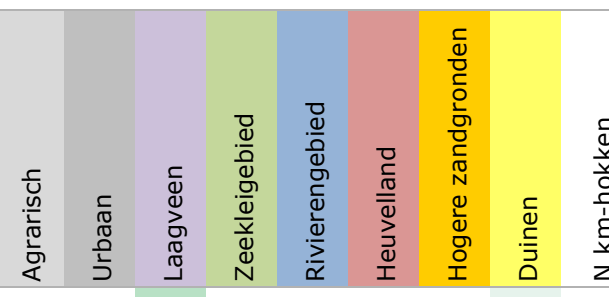

0.15

$\begin{array}{llll}0.02 & 0.02 & 0.13 & 0.21\end{array}$

0.05

$z$ Nederlandse naam

50 Veenplatvoetje

234 Scheefvlek-platvoetje

20 Snavelzeggeplatvoetje

86 Moerasplatvoetje

297 Gewoon schaduwplatvoetje

0.17

9 Daslookgitje

$0.060 .03 \quad 7$ Eikenspitsbek

$0.08 \quad 19$ Dennenspitsbek

$\begin{array}{lllllll}0.09 & 0.03 & 0.06 & 0.03 & 0.01 & 203 \text { Klompvoetje }\end{array}$

$\begin{array}{lllll}0.10 & 0.15 & 0.03 & 171 \text { Vlinderstrikje }\end{array}$

$\begin{array}{llllll}0.00 & 0.00 & 0.12 & 0.01 & 0.19 & 0.23\end{array}$

1174 Gewone snuitvlieg

$\begin{array}{lllllll}0.10 & 0.08 & 0.01 & 0.09 & 0.14 & 792 \text { Witte halvemaanzweefvlieg }\end{array}$

$0.00 \quad 0.08$

$\begin{array}{llll}0.07 & 0.09 & 0.10 \quad 536 \text { Gele halvemaanzweefvlieg }\end{array}$

8 Donkere veenzweefvlieg

0.10

0.16

$0.22 \quad 451$ Gele veenzweefvlieg

$\begin{array}{lll}0.11 & 0.12 \quad 97 \text { Zandlanglijf }\end{array}$

$\begin{array}{llll}0.05 & 0.05 & 14 & \text { Kleine gevlekte langlijf }\end{array}$

39 Grote gevlekte langlijf

$0.09 \quad 0.06 \quad 32$ Donkere langlijf

$0.08 \quad 89$ Kleine langlijf

$\begin{array}{llll}0.00 & 0.05 & 0.03 & 0.03\end{array}$

$\begin{array}{lllllll}0.08 & 0.00 & 0.14 & 0.01 & 0.10 & 1556 \text { Grote langlijf }\end{array}$

$0.05 \quad 0.00$

$0.03 \quad 0.12$

0.08

52 Graslanglijf

18 Heidelanglijf

$0.20 \quad 34$ Gewone bronzweefvlieg

$0.150 .00 \quad 14$ Beek-bronzweefvlieg

$0.07 \quad 0.03 \quad 22$ Grote bronzweefvlieg

\begin{tabular}{r|l|l|l}
0.00 & 0.11 & 22 & Grote bronzweefvlieg \\
\hline
\end{tabular}

$\begin{array}{lllllllll}0.03 & 0.00 & 0.06 & 0.00 & 0.16 & 0.01 & 0.03 & 1420 & \text { Menuetzweefvlieg }\end{array}$

0.1136 Onderbroken-bandzweefvlieg

\begin{tabular}{ll|l|l|l|l}
0.09 & 0.03 & 0.25 & 0.07 & 1220 & Bessenbandzweefvlieg
\end{tabular}

\begin{tabular}{|l|l|l|l|l|l|l|l}
0.04 & & 0.07 & 0.08 & 0.14 & 541 Bosbandzweefvlieg \\
\hline 0.00 & 0.05 & 0.03 & 0.15 & 0.10 & 621 Kleine bandzweefvlieg \\
\hline
\end{tabular}

$\begin{array}{llllll}0.00 & 0.03 & 0.09 & 0.11 & 214 \text { Donkere wespvlieg }\end{array}$

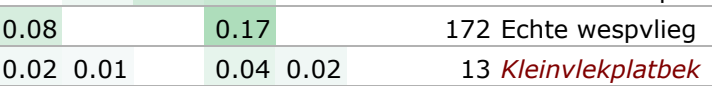

\begin{tabular}{l|r|rrr}
0.02 & 0.06 & 0.00 & 6 Grootvlekplatbek \\
0.01 & 0.05 & 0.04 & 17 Kortlijfplatbek
\end{tabular}

$\begin{array}{llllll}0.00 & 0.29 & 0.25 & 0.03 & 584 \text { Moeraszweefvlieg }\end{array}$

$\begin{array}{llll}0.13 & 0.11 & 0.18 & 835 \text { Hommelreus }\end{array}$

$0.11 \quad 8$ Gele reus

$\begin{array}{llll}0.20 & 0.05 & 0.01 & 922\end{array}$ Witte reus

$\begin{array}{llllllll}0.06 & 0.03 & 0.20 & 0.05 & 0.01 & 922 & \text { Witte reus } \\ 0.33 & & 0.04 & 0.07 & 0.05 & & 750 \text { Stadsreus }\end{array}$

0.00

$\begin{array}{lll}0.00 & 0.02 & 0.09\end{array}$

109 Platte zweefvlieg

$0.23 \quad 27$ Streepcitroenzweefvlieg

$\begin{array}{lllll}0.01 & 0.02 & 0.02 & 0.08 & 23 \text { Gewone citroenzweefvlieg }\end{array}$

$\begin{array}{llll}0.00 & 0.02 & 0.05 & 13 \text { Boscitroenzweefvlieg }\end{array}$

$\begin{array}{llll}0.00 & 0.07 & 15 \text { Kleine grijze bladloper }\end{array}$

\begin{tabular}{lllll|lll}
0.00 & 0.12 & 0.01 & 0.21 & 0.04 & 989 & Gewone rode bladloper
\end{tabular}

$\begin{array}{llllllll}0.00 & 0.05 & 0.06 & 0.04 & 0.02 & 0.00 & 326 & \text { Grote gouden bladloper }\end{array}$

$\begin{array}{llll}0.01 & 0.04 & 0.06 & 10 \text { Kleine rode bladloper }\end{array}$

0.1613 Gevlekte gouden bladloper 
Wageningen Environmental Research Postbus 47

6700 AA Wageningen

T 0317480700

www.wur.nl/environmental-research

Wageningen Environmental Research

Rapport 2920

ISSN 1566-7197
De missie van Wageningen University \& Research is 'To explore the potential of nature to improve the quality of life'. Binnen Wageningen University \& Research bundelen Wageningen University en gespecialiseerde onderzoeksinstituten van Stichting Wageningen Research hun krachten om bij te dragen aan de oplossing van belangrijke vragen in het domein van gezonde voeding en leefomgeving. Met ongeveer 30 vestigingen, 5.000 medewerkers en 10.000 studenten behoort Wageningen University \& Research wereldwijd tot de aansprekende kennisinstellingen binnen haar domein. De integrale benadering van de vraagstukken en de samenwerking tussen verschillende disciplines vormen het hart van de unieke Wageningen aanpak. 



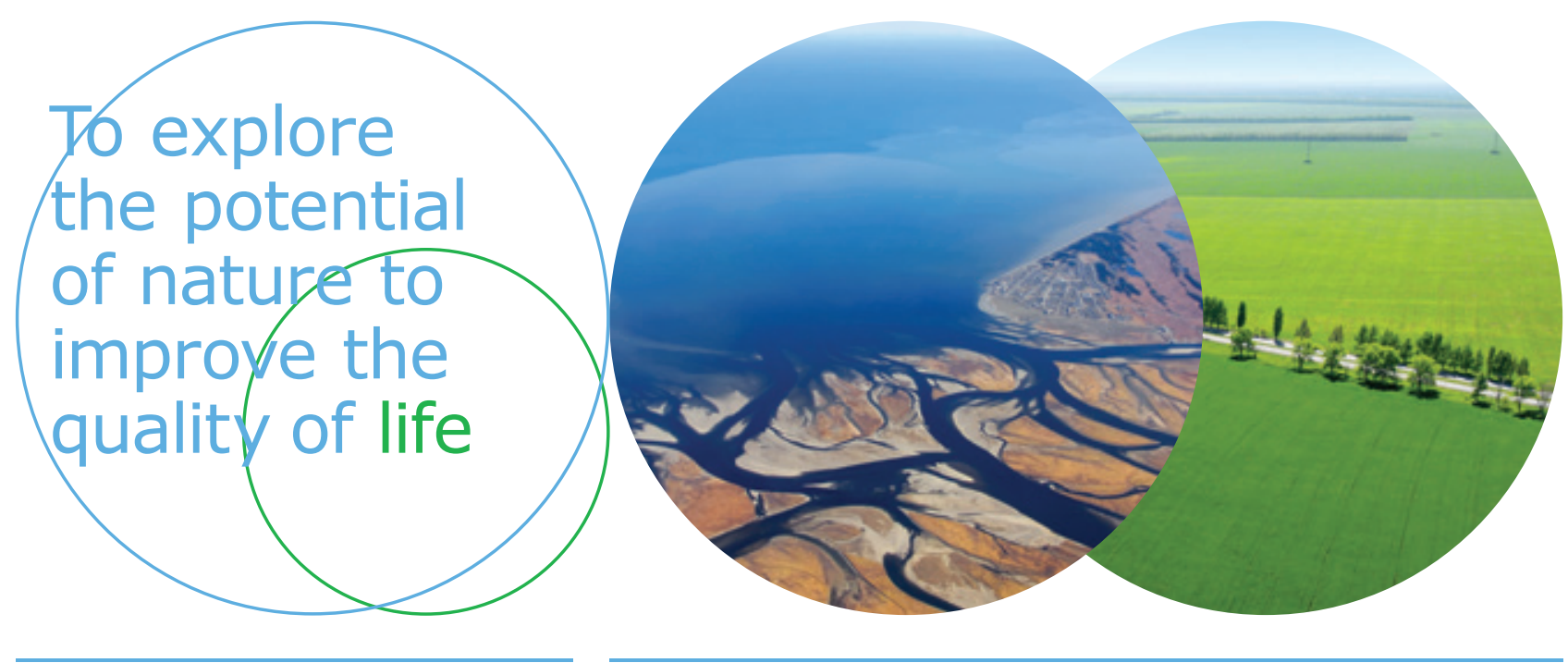

Wageningen Environmental Research Postbus 47

$6700 \mathrm{AB}$ Wageningen

T 317480700

www.wur.nl/environmental-research

Rapport 2920

ISSN 1566-7197
De missie van Wageningen University \& Research is 'To explore the potential of nature to improve the quality of life'. Binnen Wageningen University \& Research bundelen Wageningen University en gespecialiseerde onderzoeksinstituten van Stichting Wageningen Research hun krachten om bij te dragen aan de oplossing van belangrijke vragen in het domein van gezonde voeding en leefomgeving. Met ongeveer 30 vestigingen, 5.000 medewerkers en 10.000 studenten behoort Wageningen University \& Research wereldwijd tot de aansprekende kennisinstellingen binnen haar domein. De integrale benadering van de vraagstukken en de samenwerking tussen verschillende disciplines vormen het hart van de unieke Wageningen aanpak. 